\title{
دور مواقع التواصل الاجتماعي في تحفيز الشباب الجامعي على المشاركة في القضايا المجتمعية "دراسة ميدانية"
}

\section{د.عزة جلال عبدالله حسين(")}

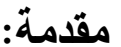

برزت في الآونة الأخيرة مواقع التواصل الاجتماعي على شبكة الإنترنت وحظيت

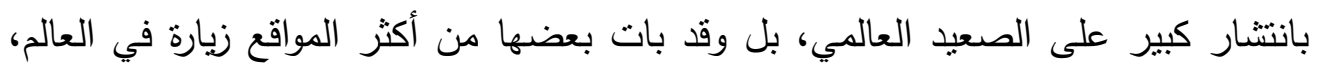

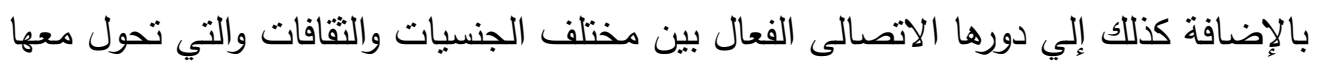
العالم إلي قرية كونية صغيرة،ولقد أحدثت مواقع التواصل الاجتماعي وفرة وتدفق هائل دائل في المعلومات في كافة المجالات السياسية والاقتصادية والاجتماعية، بالإضافة الي دورها الفعال

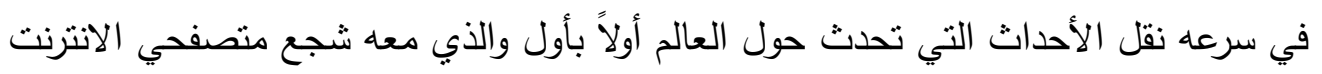
من مختلف الفئات ولاسيما الثباب الجامعي من الإقبال عليها والتفاعل معها لكونها وسيلة لتقريب وجهات النظر والروئ مع الآخرين، ووسيلة لنقل أفكارهم وآرائهم حول القضايا

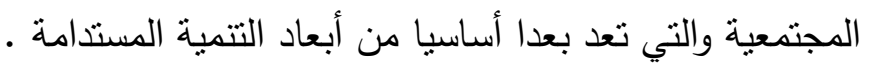
ومن الجدير بالذكر أن مواقع التواصل الاجتماعي اليوم أصبحت جزئ أسعاد أساسيا في حياة

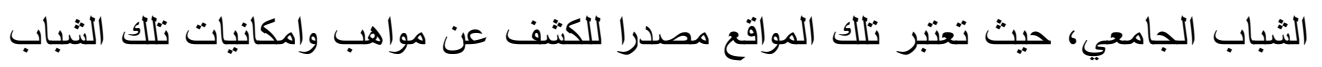
وميولهم ومثاركتهم في شتي مجالات الانشطة الثقافية والمجتمعية ، فالتتمية المستدامة المتعلقة بالقضايا المجتمعية لا يمكن أن تتم بدون الثباب الذي يعتبر التبر أداة التتمية وله دور

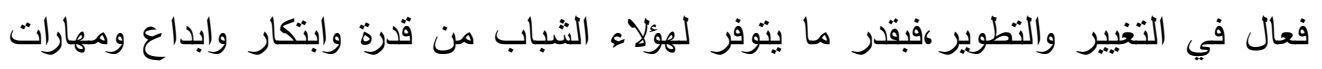

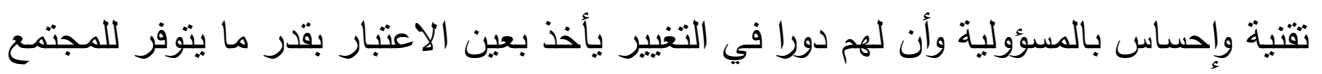
القدرة الذاتية علي التطور والنمو.

وعلي صعيد الثباب الجامعي السعودي أصبحنا نري تعامل قطاع كبير من فئة الثباب مع مواقع التواصل الاجتماعي مستخدما الموضوعات المتاحة عبر هذة المواقع في شتي نعابي

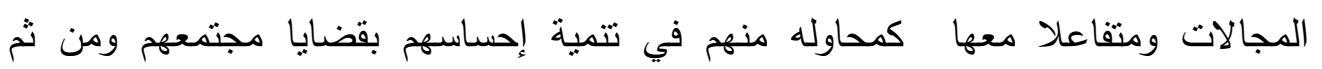
مشاركتهم في هذه القضايا المجتمعية وكذلك مشاركة الآخرين الحديث عن تلكئك القضايا والموضوعات ومحاوله إيجاد الحلول لها من أجل تتمية مستدامة للمجتمع. 
ولا يخفي علي الجميع أن مواقع التواصل الاجتماعي وبالتحديد(فيس بوك-توتير) لعبت ولازالت تلعب دورا لا بيتهان به في زيادة مساحة حرية التعبير عن الآراء والمشاركة في بواني

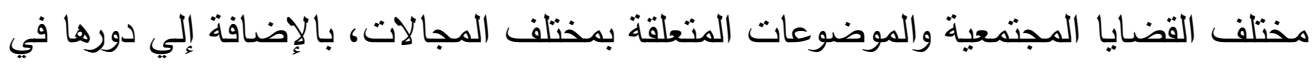

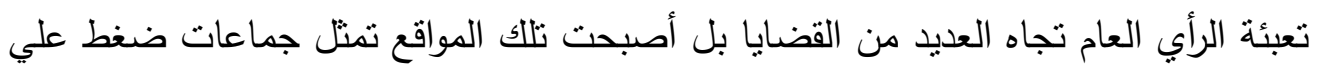
الجهات المسئولة باختلاف تخصصاتها من أجل اتخاذ التدابير والإجراءات اللازمة لحل بعض القضايا في المجتمع من اجل تتمية مستدامه حيث تمثل القضايا المجتمعية عقبة في سبيل تحقيق التتمية المستدامة في المجتمعات المختلفة.

مشكلة الاراسة:

أظهرت الإحصاءات العالمية تزايد الإقبال على استخدام مواقع التواصل الاجتماعي في

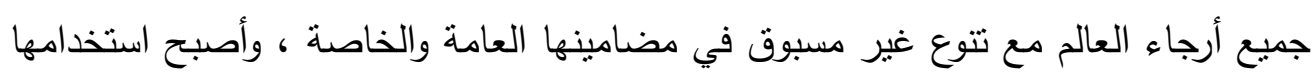

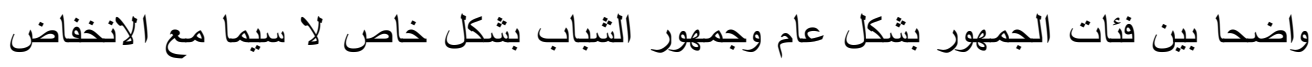

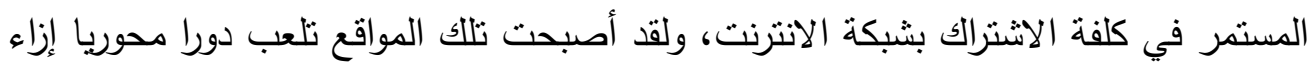

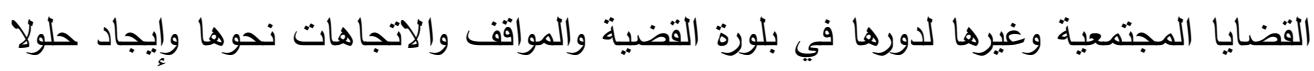

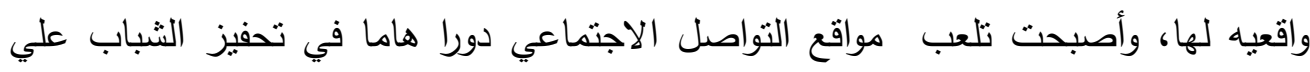

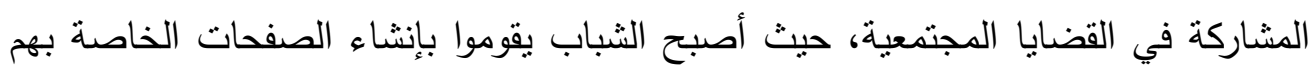

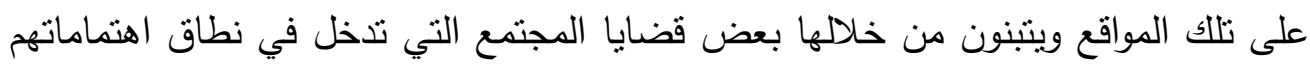

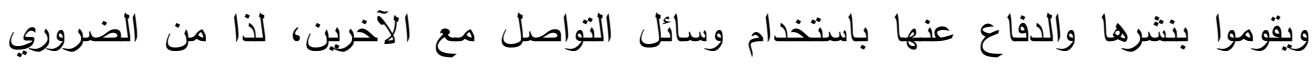

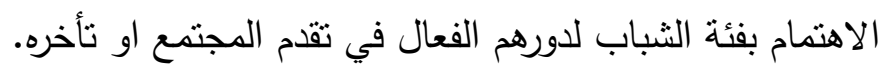
لذا تتبلور مشكلة الدراسة في معرفة:ما دور مواقع التواصل الاجتماعي في في تحفيز

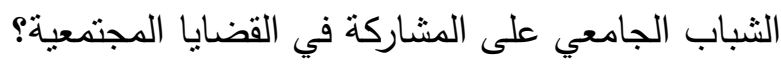
أهمية الدراسة:

\section{تتقسم أهمية الدراسة الحالية إلى:}

\section{أ- أهبة عملية تطيقية:}

ا-تظهر أهميـة هذه الدراسـة في إنها تسعي لمعرفة دور مواقع التواصل الاجتماعي التي التي

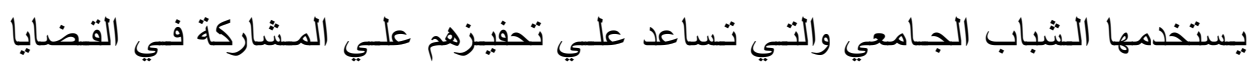
المجتمعية ليصبحوا عنصر أكثر فعالية في بناء مجتمعهم. 
ب-توجيـه القـائمين علـي اتخـاذ القـرارات والجهـات المسئولة حـول أهميـه مواقـع التواصـل الاجتماعي في دعم واستمرار مسبرة التنمية ومشاركه الثباب فيها. ب-تحديد الدور الذي تقوم بـه مواقع التواصل الاجتمـاعي في ظلـ النطور التكنولوجي الهائل، ومدى قدرتها علي خدمة المجتمع قضاياه. ب- أهمية علمبة نظرية: ا-تتاولت هذه الدراسة وسيلة هامة من وسائل الاتصال الحديث والمنمتلة في مواقع التواصل الاجتماعي، والتي أصبحت ذات انتشار واسع ومكملا لوسائل الإعلام التقليدية.

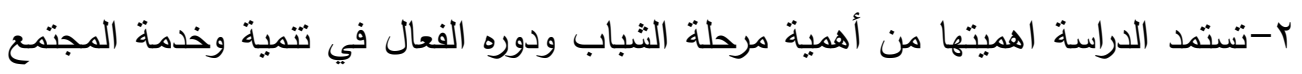
والذي يعتبر محورا هاما من محاور التتمية المستدامة.

r-ارتفاع مستخدمي مواقع التواصل الاجتماعي حيثوصل عدد مستخدميها في نهاية عام

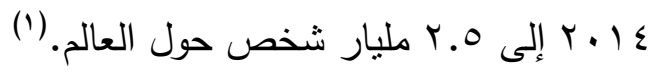

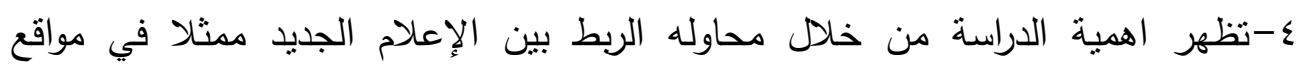
التواصل الاجتماعي وكيفية توظيفه لخدمه القضايا المجتمعية من أجل تتمية مستدامة لإنة ل ل ل المجتمعات.

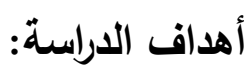
تتمثل أهداف الدراسة الحالية فيما يلي:

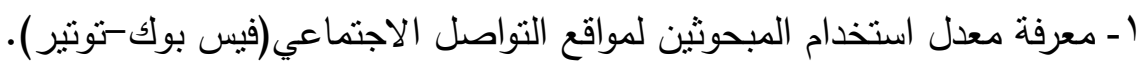

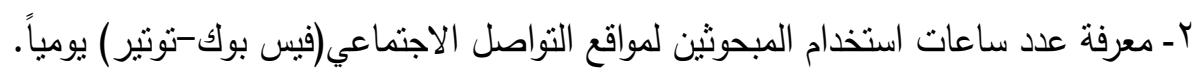

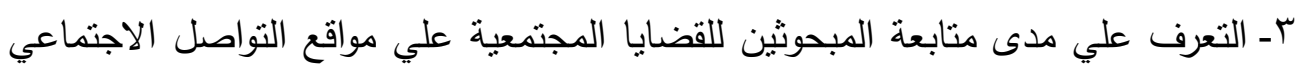

$$
\text { ( فيس بوك-توتير ). }
$$

ع- معرفة الصفحات التي تنتاول القضايا المجتمعية علي مواقع التواصل الاجتماعي (فيس بوك-توتير ) ويشارك بها المبحوثتون. هـ التعرف علي الفئات التي يتتاقش معها المبحوثون حول القضايا المجتمعية علي مواقع

$$
\text { التواصل الاجتماعي (فيس بوك-توتير). }
$$

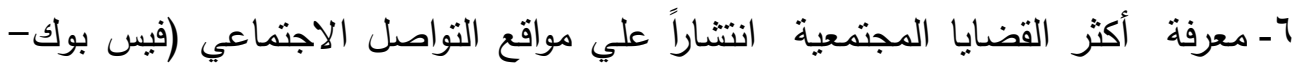
توتير ) من وجهة نظر المبحوثين. 
V- معرفة ددى نجاح مواقع التواصل الاجتماعي( فيس بوك-توتير) في علاج أي من القضايا المجتمعية من وجهة نظر المبحوثين.

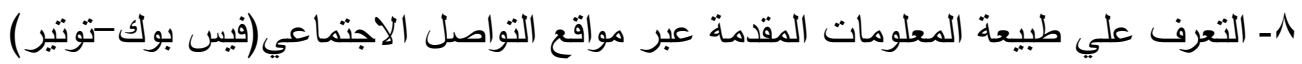
حول القضايا المجتمعية من وجهة نظر المبحوثين. 9 ـ معرفة دور المبحوثين تجاه المنشورات المتعلقة بالقضايا المجتمعية علي مواقع التواصل

$$
\text { الاجتماعي (فيس بوك-توتير) . }
$$

• ا ـ معرفة درجة اعتماد المبحوثين علي مواقع التواصل الاجتماعي(فيس بوك-توتير) في الحصول علي المعلومات حول القضايا المجتمعية.

1اـ التعرف علي درجة ثقة المبحوثين في المعلومات التي يحصلوا عليها حول القضايا

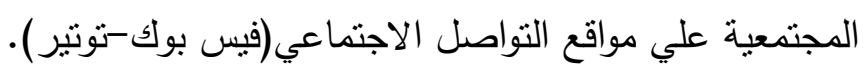

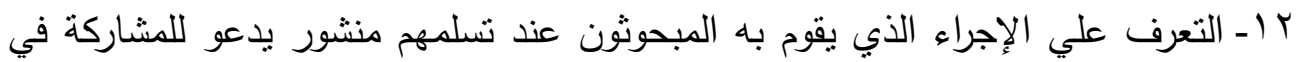

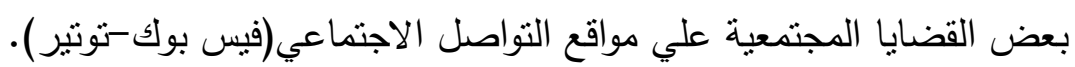

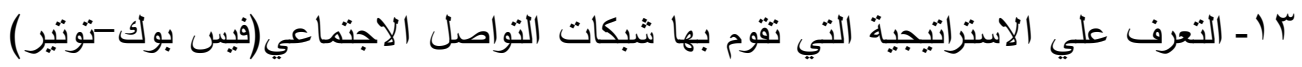
من أجل تحفيز الثباب الجامعي نحو المشاركة في القضايا المجتمعية من وجهة

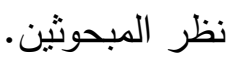
ع (ـ معرفة أهم القضايا المجتمعية التي يهتم بمثابعتها المبحوثون ويبدون الرأي فيها من خلال شبكات التواصل الاجتماعي (فيس بوك-توتير ).

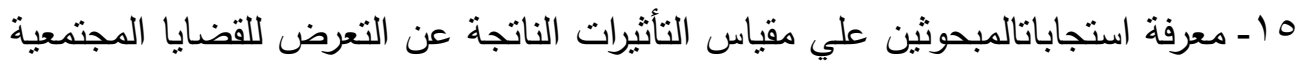

$$
\text { علي مواقع التواصل الاجتماعي (فيس بوك-تونير ). }
$$
17

$$
\text { التواصل الاجتماعي ( فيس بوك-تونتير ). }
$$

الإطار النظري: مدخل الاعتماد علي وسائل الإعلام:

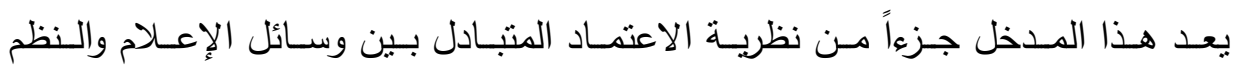
الاجتماعية، ففي عام 9 ام، قدم كل من ساندرابول - روكيتش وملفين ديفلور أول إطار

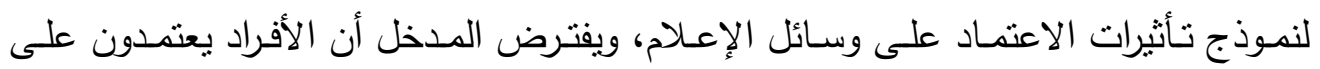

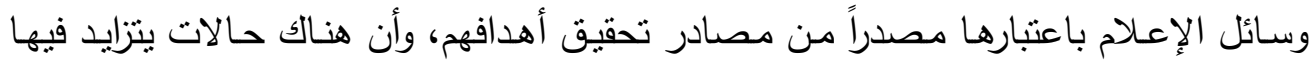

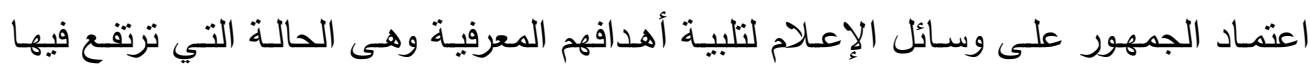

$$
\text { درجات الصراع داخل المجتمع أو خارجه . }
$$


ويحدد هذا المدخل التأثيرات الناتجة عن الاعتماد على وسائل الإعلام فيما يلي(؟) 1-التأثيرات المعرفية:Cognitive Effects والتي تنمثل فيما يلي:

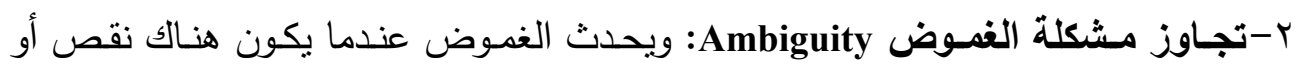
تضارب في المعلومات المقدمة من وسائل الإعلام وبخاصة في الأحداث غير المتوقعة،

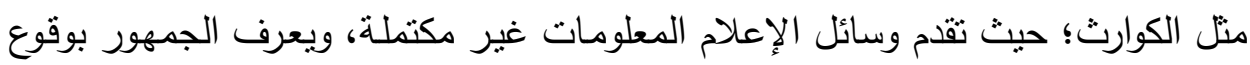

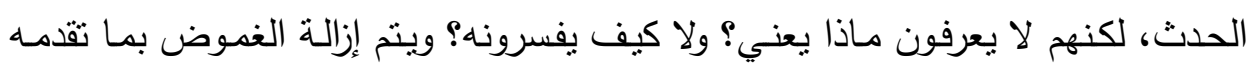

$$
\text { وسائل الإعلام من معلومات. }
$$

r-تشكيل الاتجاهات Attitude Formation: تسهم وسائل الإعلام في تكوين اتجاهات

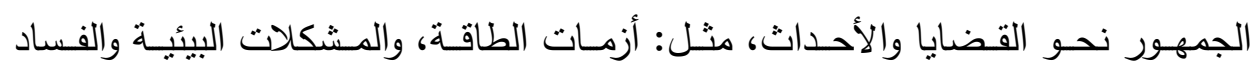

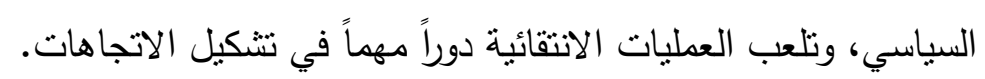

ع-ترتيب الأولويات Agenda-Setting: تلعب وسائل الإعلام دوراً في ترتيب أجندة الجمهور

$$
\text { نحو الموضوعات والقضايا المطروحة. }
$$

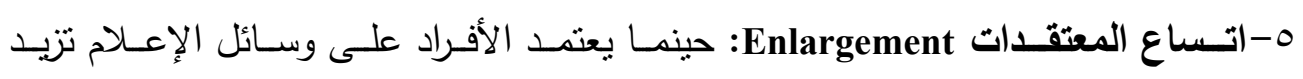
معتقداتهم ومعارفهم عن الناس والأمساكن وغيرهم، وينم تتظيم هذه المعتقدات في فئات،

$$
\text { مثل: الأسرة، الدين، السياسة، وهكذا. }
$$

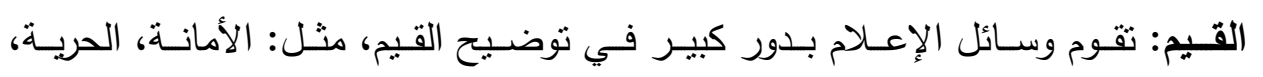

$$
\text { المساواة... و وغيرها. }
$$

צ-r-التـأثيرات الوجدانيـة Affective effects: تشير التأثنيرات الوجدانيـة إلى المشاعر

$$
\text { والعواطف، التي ترنبط بالحب والكراهية، وتتمثل التأثثرات الوجدانية فيما يلي: لئيز }
$$

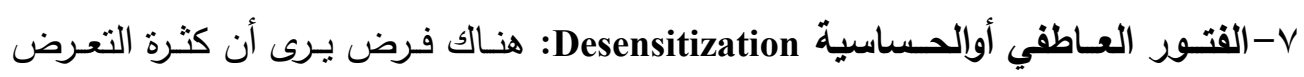

$$
\text { لموضوعات العنف في وسائل الإعلام يقلل من الرغبة في مساعدة الآخرين. }
$$

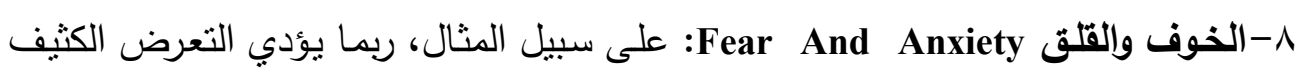

للاراما التي تصور العنف في مدينة ما، وإلى خوف الناس وقلقهم من الإقامة في هذه المدينة . 9-التأثير الأخلاقي والاغتراب Morale And Alienation: في المجتمعات التي تقوم وسائل الإعلام فيها بأدوار اتصال رئيسة، فإنها تؤثر في المستوى الأخلاقي والاغتراب لدي أفراد المجتمع.

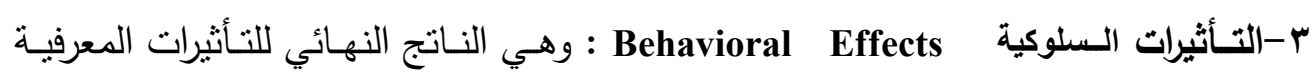

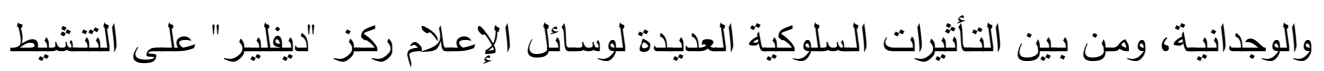


Activation وعدم التتشيط Deactivation، والتتشيط يعنـي: قيام الفرد بعدل مـا نتيجـة التعرض للوسيلة الإعلامية.

\section{ويقوم مدخلالاعتماد على عدة افتراضات رئيسية هي : لإعنه}

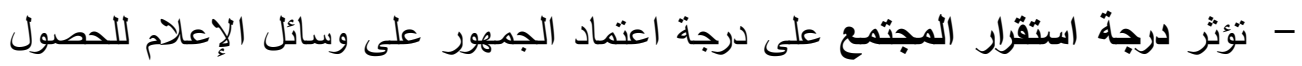

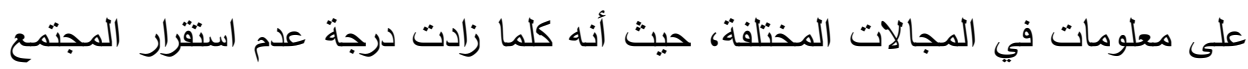

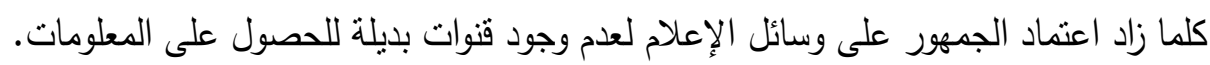

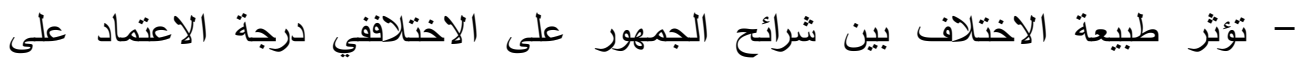

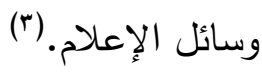

ويتميز مدخل الاعتمادبعدة مزايا منها إنه يقوم على عدة نأثيرات محتملة لوسائل الإعلام

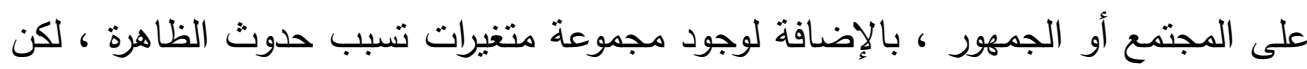

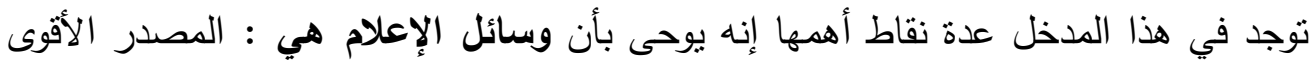

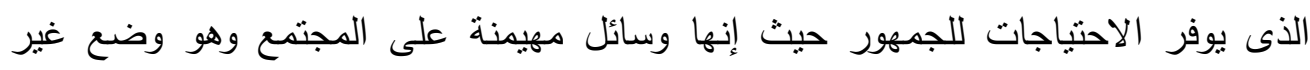

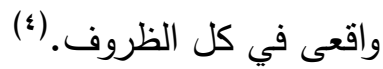

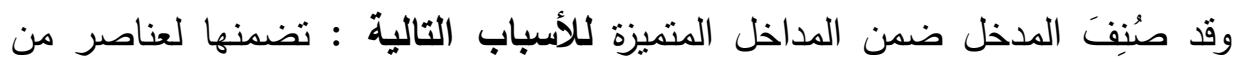

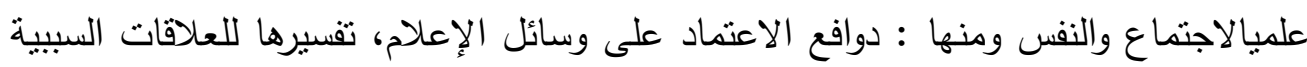

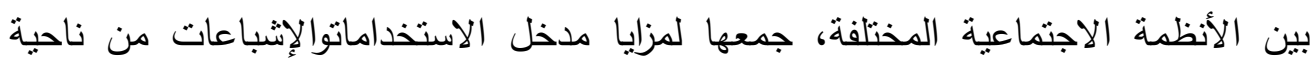

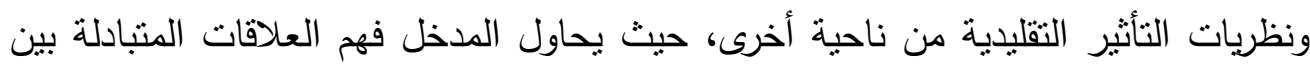

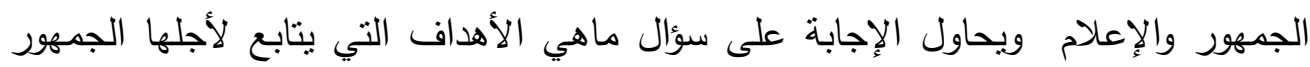

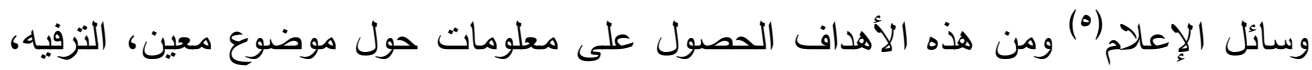

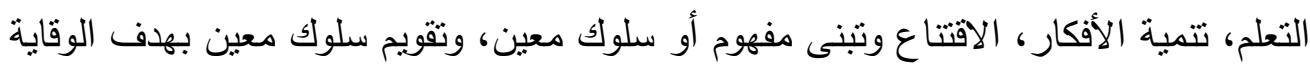

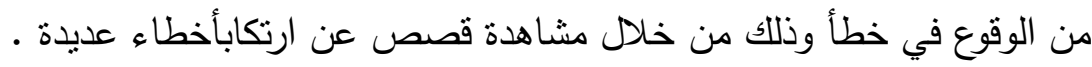

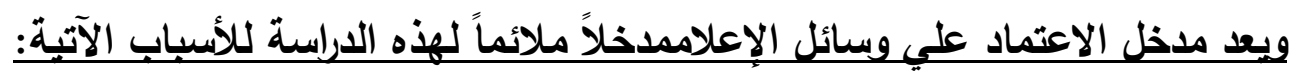

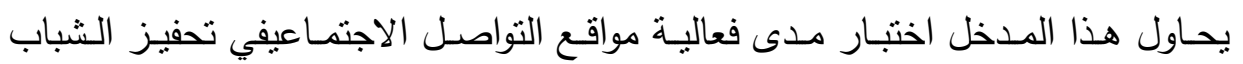

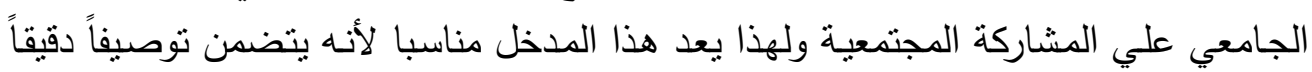
لدوافع الاعتماد وتأثيراته المختلفة.

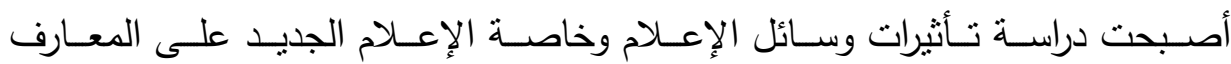

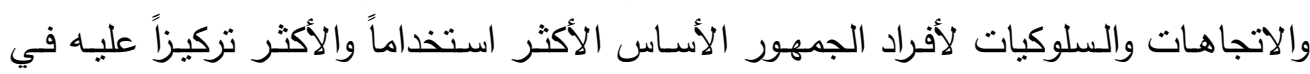

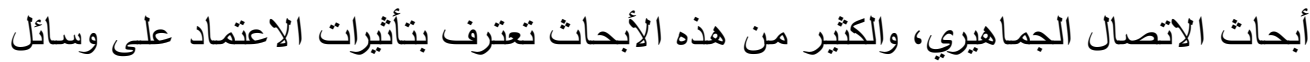

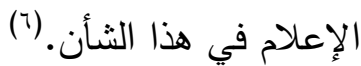




\section{الاراسات السابقة:}

قامت الباحثة باستعراض الدراسات السابقة المتعلقة بموضوع الدراسة من خلال التعرض

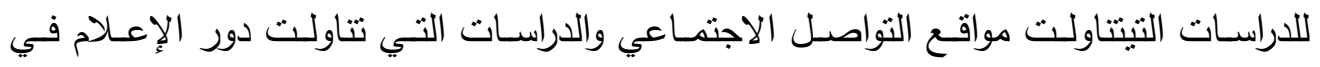
المشاركة المجتمعيةوذلكعلي النحو التالي:

\section{أولا: الدراسات التي تناولت مواقع التواصل الاجتماعي ومنها:}

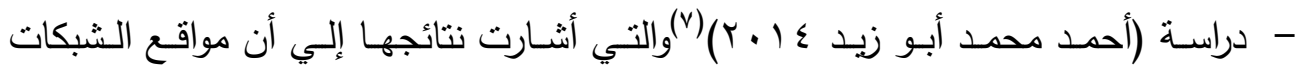

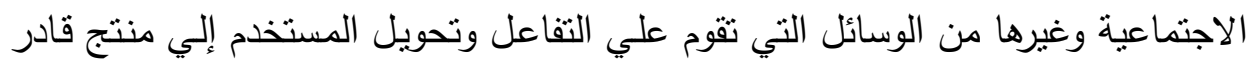

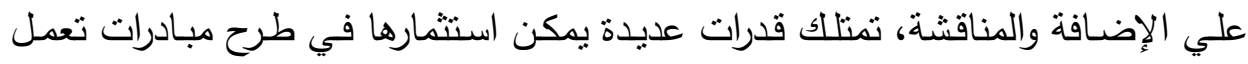

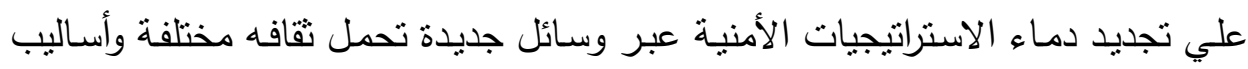
مبتكرة وقيما تدعم دور الفرد ومسئولياته.

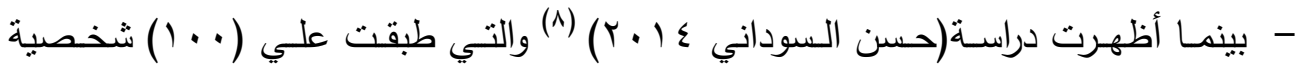
ثقافية واجتماعيه أن وسائل الإعلام الجديد تسهم بشكل فاعل في انتهاك الحياه الخاصـة

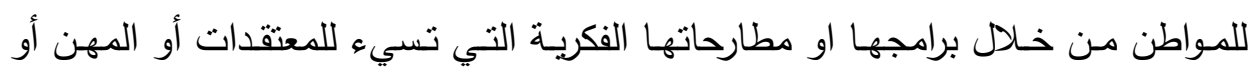

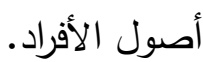

- وأكدت دراسة (محمد سليم الزبون، ضيف اله عودهء ( ـ ب)(9) أن أبرز الآثار الاجتماعية والثقافية الإيجابيةلشبكات التواصل الاجتماعي في الاطفال في سن المراهقة من فن وجهة إهدار الوقت من خلال متابعة موضوعات وألعاب غير مفيدة لساعات طويلة، والإدمان علي شبكات التواصل الاجتماعي والثعور بالرغبة الملحة لمتابعتها.

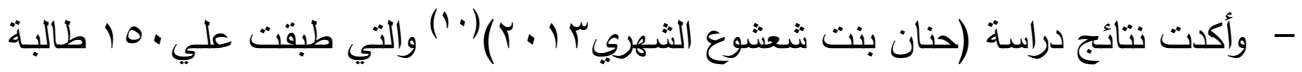
تم اختيارهم بطريقة قصدية ان استخدام الفيس بوك وتوتير له آثار إيجابية أهمها الانفتاح الفكري والتبادل التقافي، بينما جاء قلة التفاعل الأسري أحد اهم الآثار السلبية.

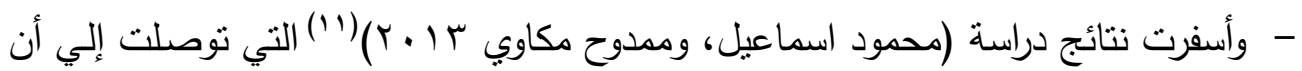

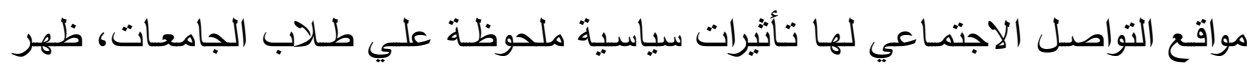

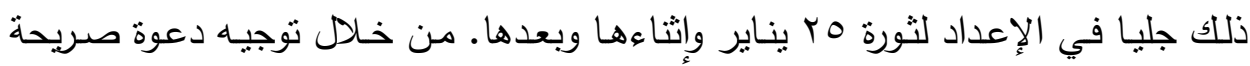

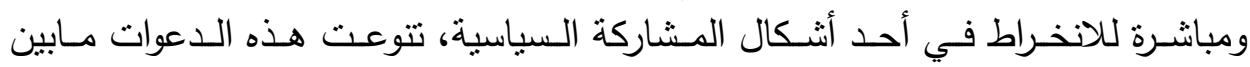
التظاهر ، التصويت، الاحتجاجات، الانضمام لمشروع أو حملة،حضور ندوة أو مؤتمر . 
Mario Guerrero، Jessica T. Feezell، Meredith Conroy) وأكدت دراسـة -

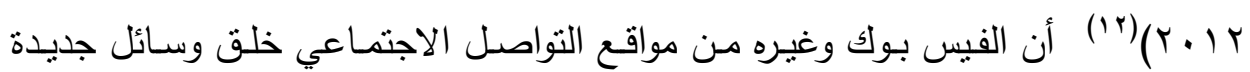

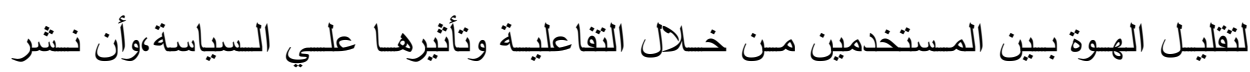

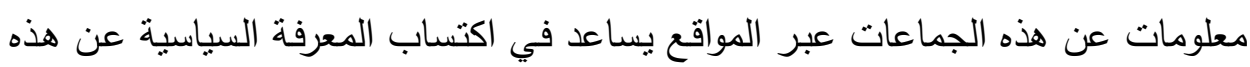
الجماعات من خلال هذه الوسيلة.

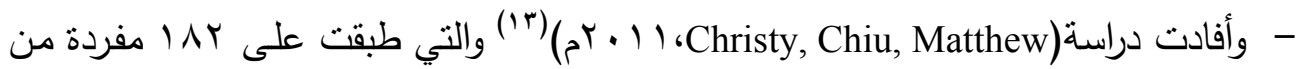
مستخدمي الفيس بوك إن معظم الطلاب يستخدمون الفيس بوك للحصول علي الاتصالات الفورية والاتصال مع أصدقائهم، ومن أكثر الدوافع أهمية عندهم هو دافع التزفيه.

ثانيا: الدراسات التي تناولت دور الإعلام في المشاركة المجتمعية.

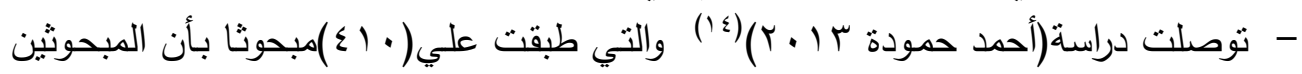
يعتقدون بعدم كفاية مـا تتتاوله شبكات التواصل الاجتماعي لتغطية القضايا المجتمعية،

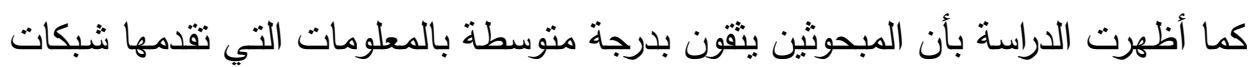
التواصل الاجتماعي.

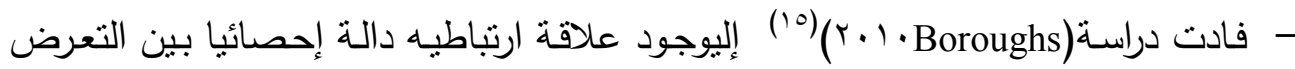

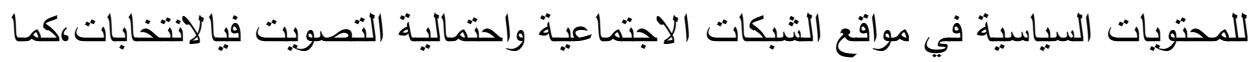

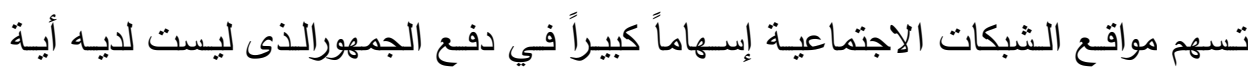
اهتمامات سياسية، إلى التصويت في الانتخابات.

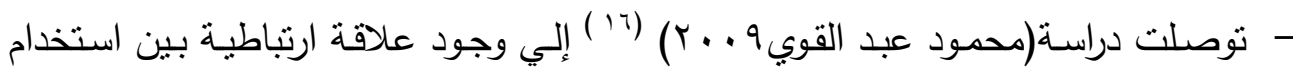

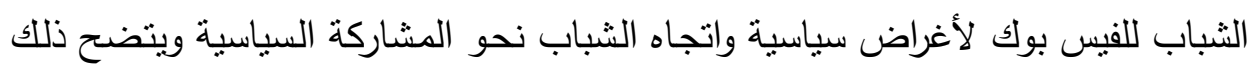
من اهية الدور الذي تقوم بـه مواقع التواصل الاجتماعي(الفيس بوك)في تشكيل اتجاه الثباب نحو المشاركة السياسية.

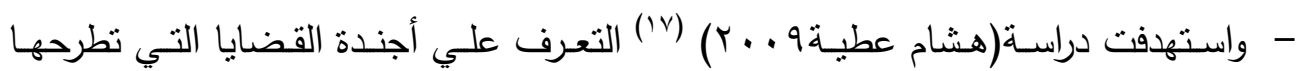

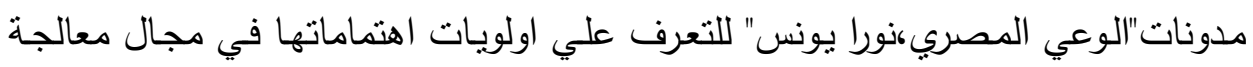

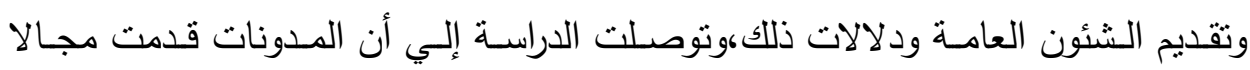

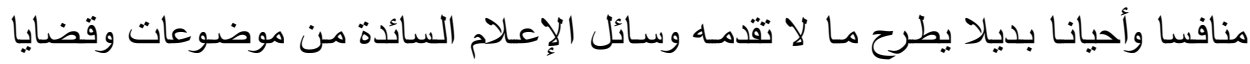

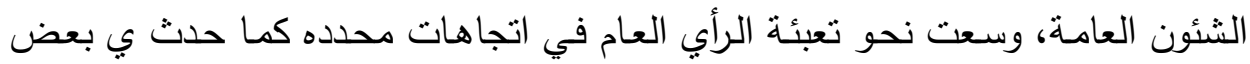

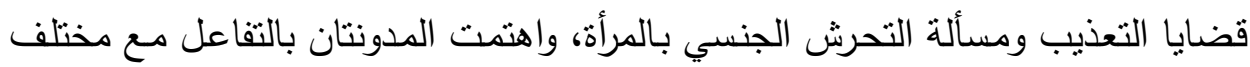

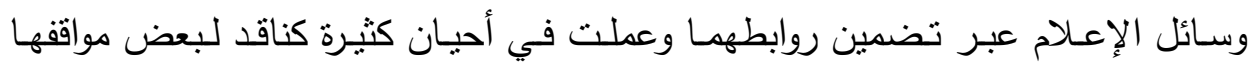
وأنماط تغطيتها للأحداث والقضايا العامة. 


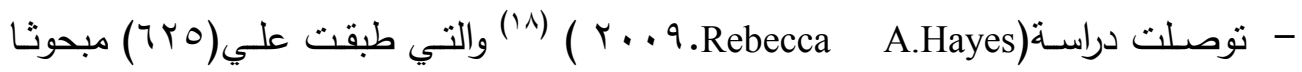

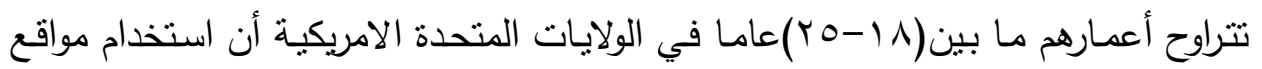

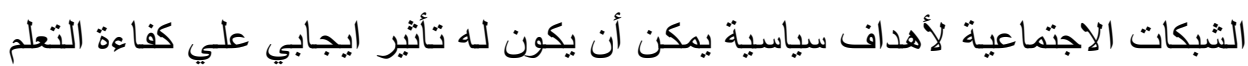

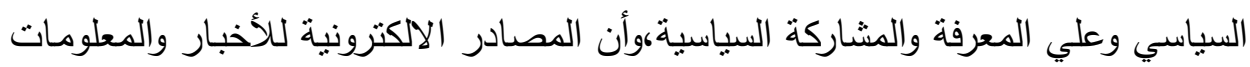

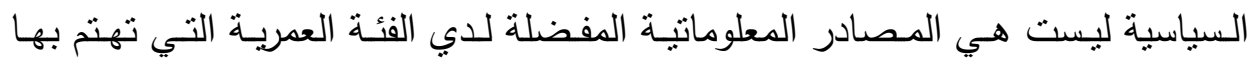
الدراسة بل كانت وسائل الإعلام التقليدية كالصحف والاخبار التلبفزيونية أكثر تفضيلا.

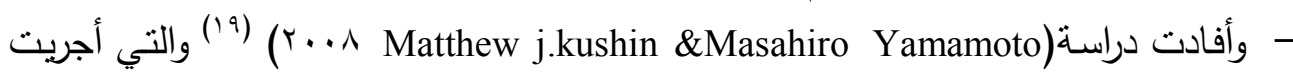
علي عينة من الشباب الجامعي الأمريكي في مقاطعها (نورث ويست ) أن هنالك علاقة

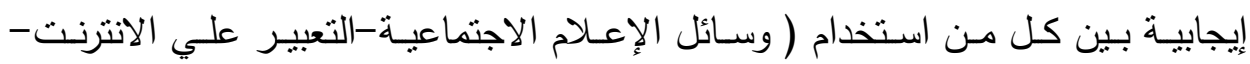

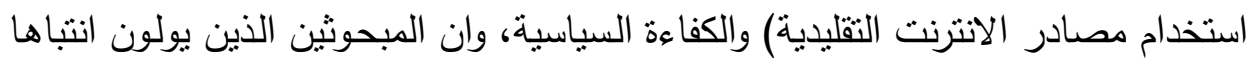

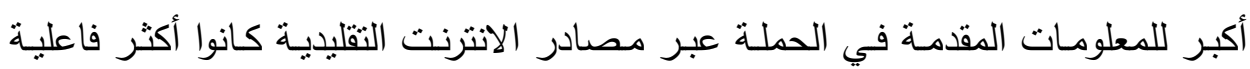

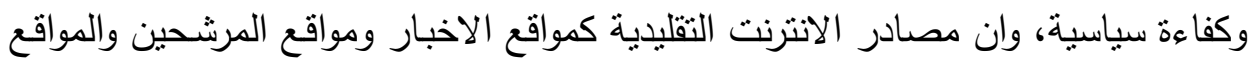

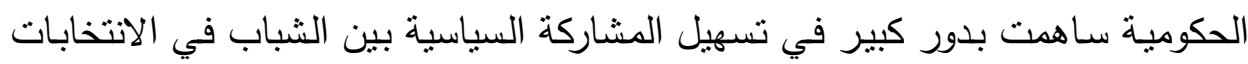
الرئاسية الامريكية.

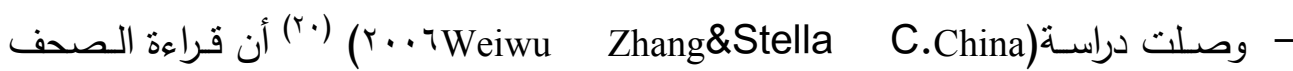
ومشاهدة الشئون العامة عبر التليفزيون تؤُثر علي المشاركة السياسية في حين لم تؤثنر

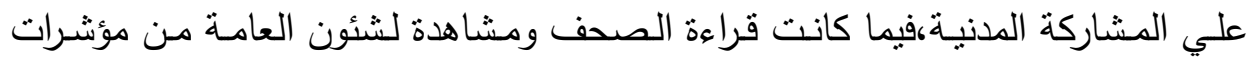

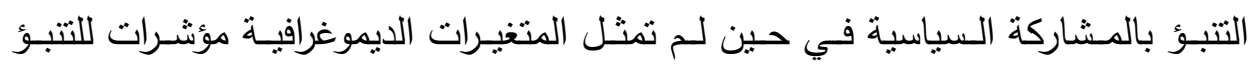
بالمشاركة السياسية.

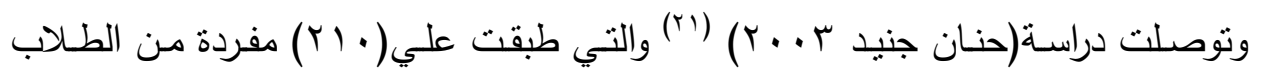

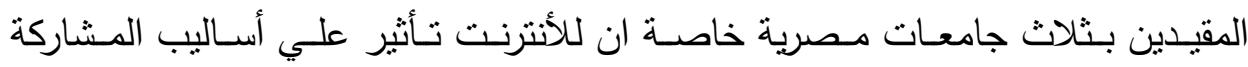

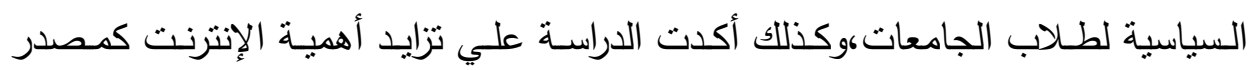
رئيسي من مصادر معلومات طلاب الجامعات.

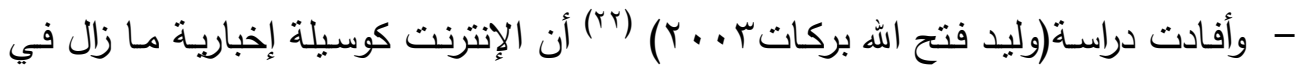

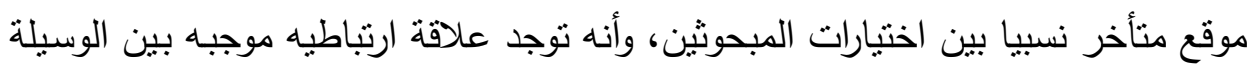

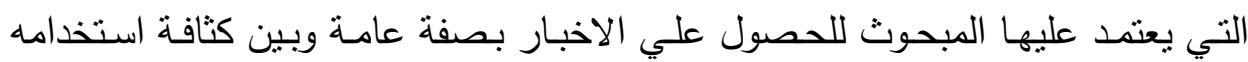
لوسائل الإعلام.

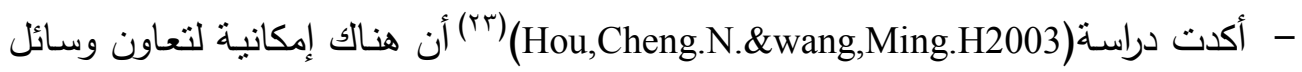
الإعلام البديل ووسائل الإعلام المطبوعة في معالجة نفس القضايا الاجتماعية. 


\section{التعليق على الاراسات السابقة وحدود الاستفادة منها:}

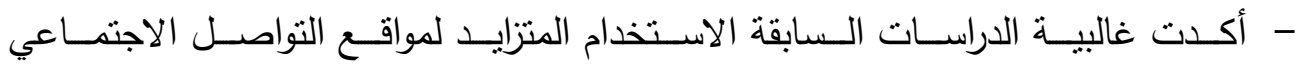

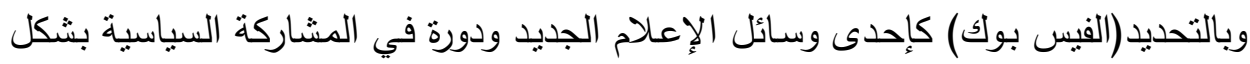
اكبر عن القضايا المجتمعية الأخرى .

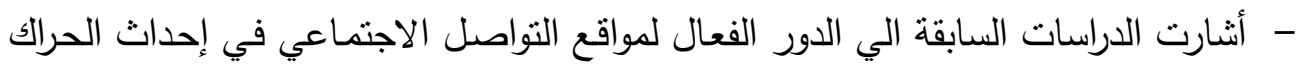
السياسي وكانت البداية لانطلاق الثورات في البلدان المختلفة.

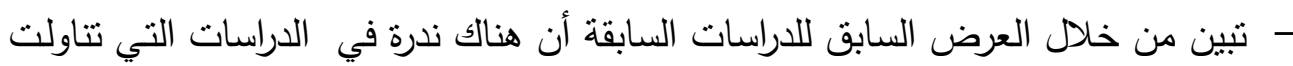
دور مواقع التواصل الاجتماعي(الفيس بوك-توتير) في تتاول القضايا المجتمعية.

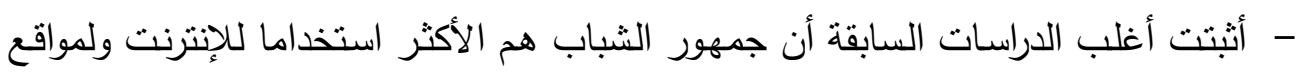
التواصل الاجتماعي وبالتحديد(الفيس بوك). - سـاعدت الدراسـات السابقة الباحثة على صياغة المشكلة البحثية، وتحديد الأداة البحثيـة

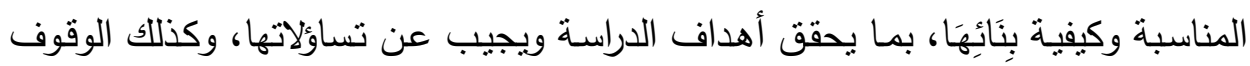
على النقاط التي لم تنتاولها الدراسات السابقة.

\section{تساؤلات الاراسةة:}

تتلخص تساؤلات الدراسة في عدد من الأسئلة يتم الاجابة عنها من خلال نتائج الدراسة وهى كالتالي :

1-ما معدل استخدام المبحوثين لمواقع التواصل الاجتماعي(فيس بوك-توتير)؛

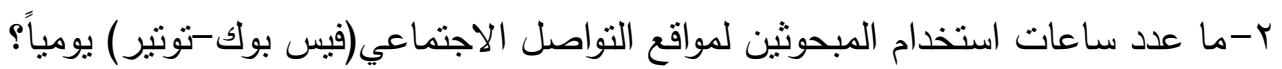

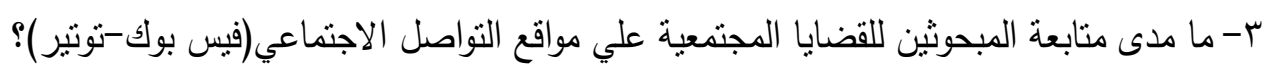

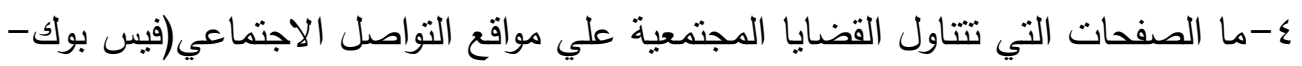

$$
\text { توتير ) ويشارك بها المبحوثون؟ }
$$

ه-ما الفئات التي ينتاقش معها المبحوثنون حول القضايا المجتمعية علي مواقع التواصل

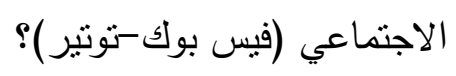

צ-ما أكثر القضايا المجتمعية انتشاراً علي مواقع التواصل الاجتماعي (فيس بوك-توتير)

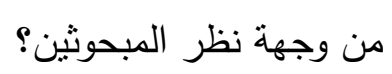

V-ما مدى نجاح مواقع التواصل الاجتماعي(فيس بوك-توتير) في علاج أي من القضايا

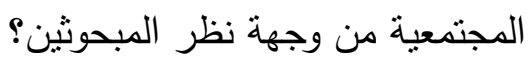
^-ما طبيعة المعلومات المقدمة عبر مواقع التواصل الاجتماعي(فيس بوكنونتوتير) حول القضايا المجتمعية من وجهة نظر المبحوثين؟ 
9-ما دور المبحوثين تجاه المنشورات المتعلقة بالقضايا المجتمعية علي مواقع التواصل

$$
\text { الاجتماعي(فيس بوك-توتير)؟ }
$$

• ا-ما درجة اعتماد المبحوثين علي مواقع التواصل الاجتماعي(فيس بوكاتوتثوتير) في

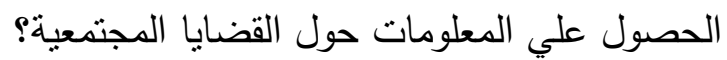

11- ما درجة ثقة المبحوثين في المعلومات التي يحصلوا عليها حول القضايا المجتمعية القئية

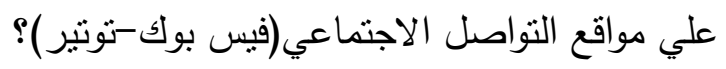

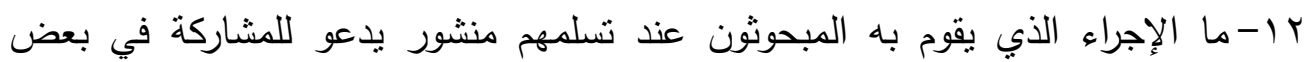

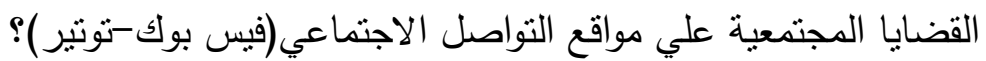

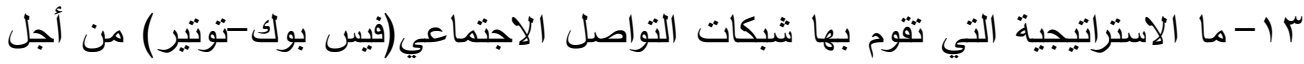

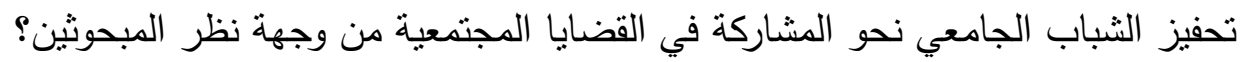

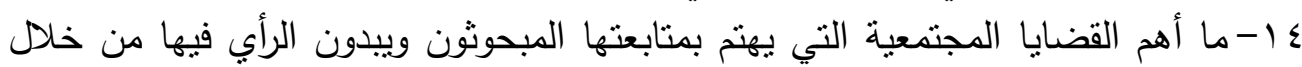

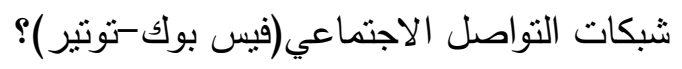

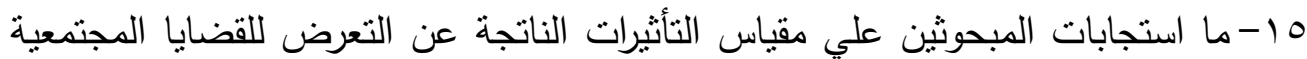

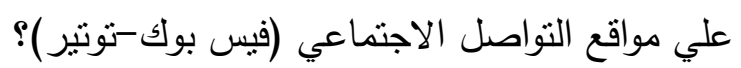

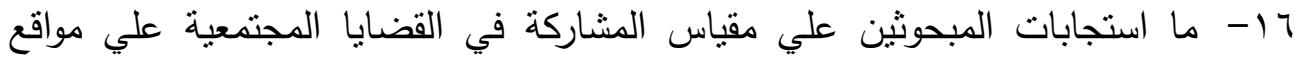

$$
\begin{aligned}
& \text { التواصل الاجتماعي (فيس بوك-توتير)؟ } \\
& \text { المفاهيم المستخدمة في الدراسة: }
\end{aligned}
$$

\section{- مواقع التواصل الاجتماعي (تعريف إجرائي)}

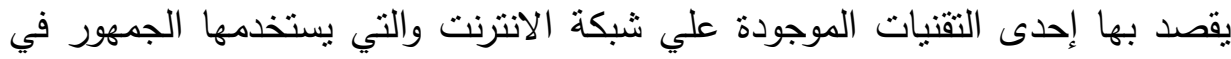

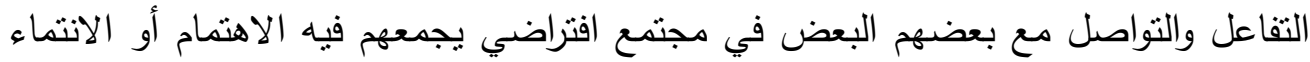

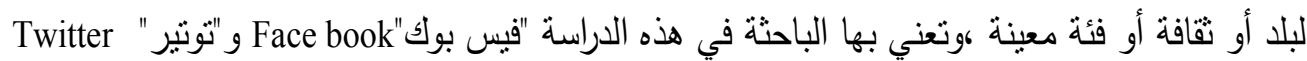

$$
\text { - تعريف الثباب الجامعي(تعريف إجرائي) }
$$

ويقصد بها المرحلة التي يلتحق فيها الثباب بالجامعات المختلفة تبعا لاهتماماتهم

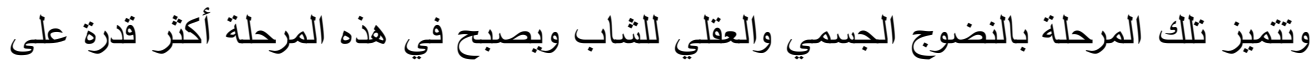

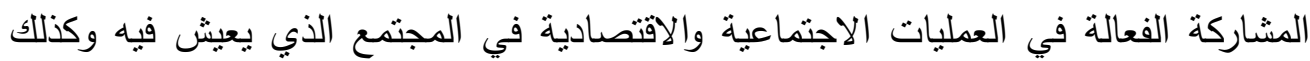
القدرة علي اتخاذ القرارات المختلفة.

\section{-}

ويقصد بها في هذه الدراسة :تلك القضايا التي بها انحراف عن المعايير المتفق عليها في ثقافة من الثقافات أو مجتمع من المجتمعات مما تشكل عقبة في سبيل التتمبة المستدامة

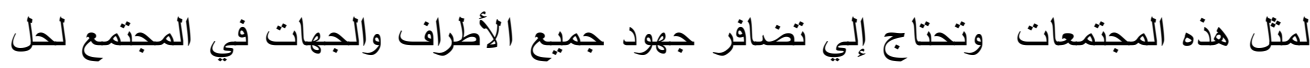




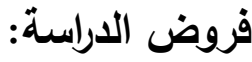

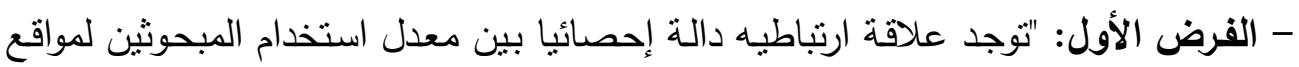

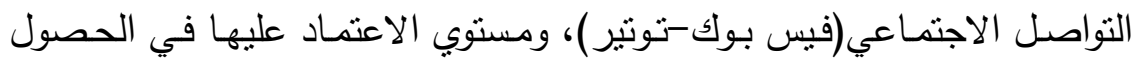

علي المعلومات حول القضايا المجتمعية". - الفرض الثاني: "توجد علاقة ارتباطيه دالة إحصائيا بين كل من معدل استخدام المبحوثين

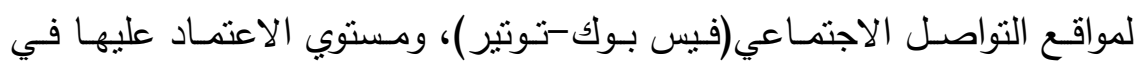

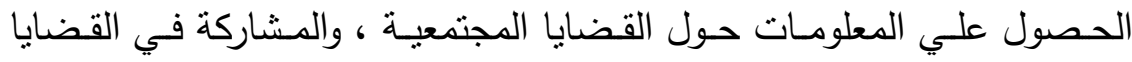

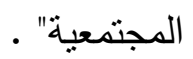

- الفرض الثالث:"توجد فروق دالة إحصائيا بين متوسطات درجات المبحوثين علي مقياس

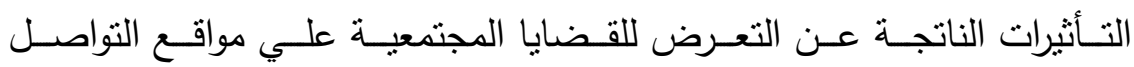

$$
\text { الاجتماعي (فيس بوك-توتير ) تبعاً للنوع". }
$$

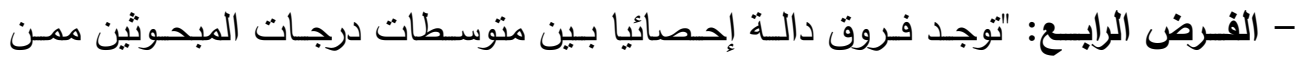

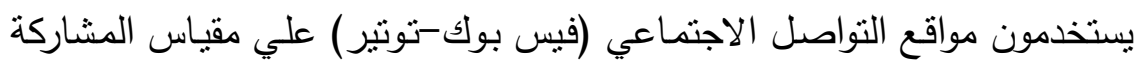
في القضايا المجتمعية تبعاً للنوع". - الفرض الخـامس:" توجد فروق دالـة إحصائيا بين متوسطات درجات المبحوثين ممـن

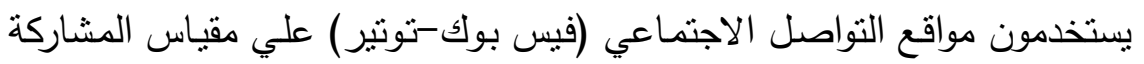

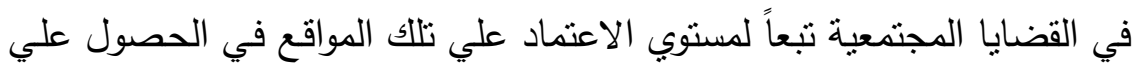
المعلومات حول القضايا المجتمعية".

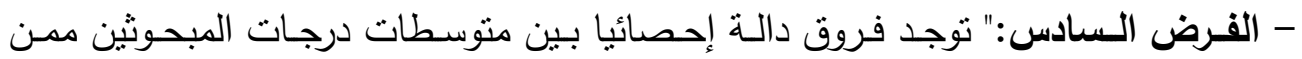

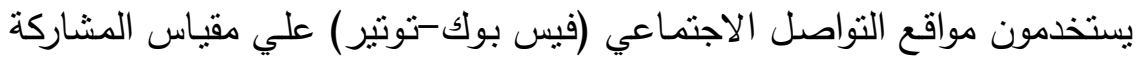

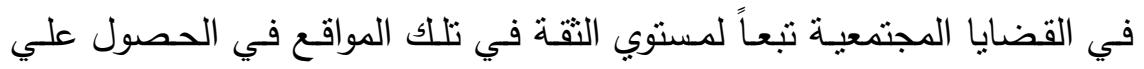
المعلومات حول القضايا المجتمعية".

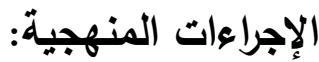

\section{نوع ومنهج الدراسة:}

تتنمي هذه الدراسة إلى البحوث الوصفية والتي تعتمد على منهج المسح بالعينة للثباب الجامعي في المملكة العربية السعودية وبالتحديد (مكة المكرمة-جدة) وذلك بهدف الحصول على معلومات دقيقة وكافية عن دور مواقع التواصل الاجتماعي في تحفيز الثباب الجامعي علي المشاركة في القضايا المجتمعية. 


\section{مجتمع الدراسة:}

يتحدد مجتمع الدراسة في عينة من الثباب الجامعي في بعض مناطق المملكة العربية

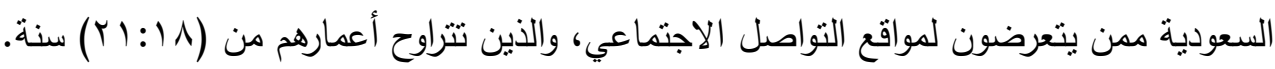
عينة الدراسة:

اعتمدت الدراسة على العينة العددية Purposive sample في اختيار أفراد العينة من المراهقين في بعض المناطق في المملكة العربية السعودية تحديدا منطقة ( مكة المكرمة- جدة- )، وذلك لقرب الباحثة من تللك المناطق وبها تمثيل للعينه التي يقوم

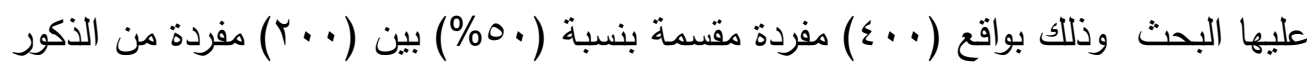

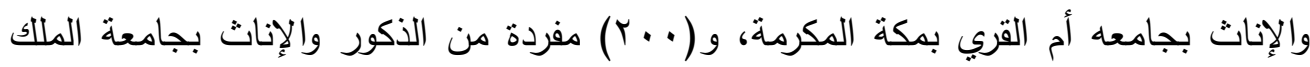
عبد العزبز بجدة. وقد روعي في اختيار العينة الشروط التالية:1-أن يكونوا من مستخدمي مواقع التواصل الاجتماعي(فيس بوك، تونير ). r-أن يكون أفردا العينة من حيث النوع (ذكور -إناث)

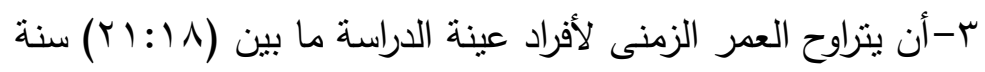

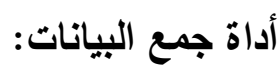

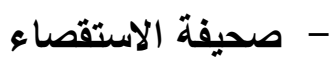

اعتمدت الباحثة على صحيفة الاستقصاء بالمقابلة لمعرفة دور مواقع التواصل

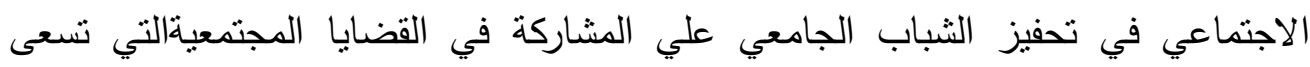

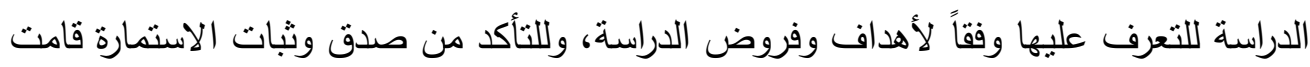

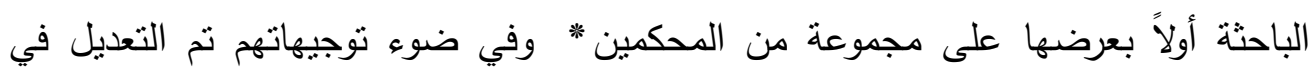

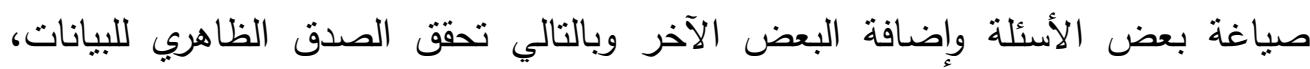
بالإضافة إلى ذلك قامت الباحثة بإجراء اختبار قبلي pre -test على عينة قوامها (• (1\%)

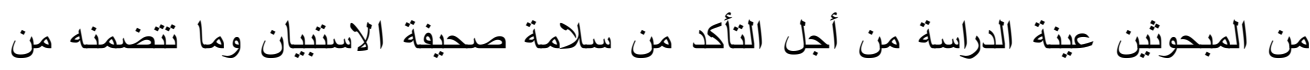

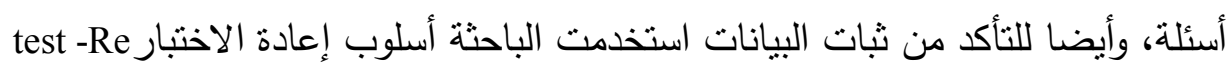
على عينة قوامها (· (\%) من العينة بعد فترة تمنلت في أسبوع من تطبيق الاستبيان وأوضحت نتائج التطبيق تطابق الاستقصاء في الحالتين وهو ما يثبر إلى معدل مرتفع للثبات 9 9 مما يثير إلى صلاحية الاستمارة ودقتها. 


\section{- مقياس المسئولية الاجتماعية.}

قامت الباحثة بالاطلاع علي بعض المقاييس التي تقيس المسئولية الاجتماعية وقد

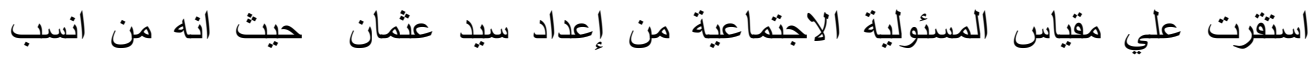

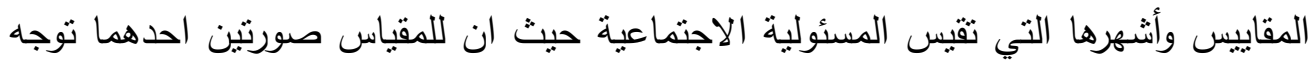
للصغار والاخر يوجه للكبار ، وتم استخدام صورة المقياس الموجهة للكبار ، وتمثلت عبارات هذا المقياس حول العبارات المتعلقة بمسئولية الفرد تجاه ذاته، والعبارات المتعلقة بمسئولية الفرد امام الجماعة التي ينتمي إليها، والعبارات المتعلقة بمسئولية الفرد تجاه المجتمع الذي لهي يعيش فيه،وقد تتاولت الباحثة في هذه الدراسة فقط العبارات المتعلقة بمسئولية الفرد تجاه المجتمع الذي يعيش فيه مع التعديل علي بعض العبارات لتتوافق مع الدراسة الحالية وما نقيسه. - أسباب تبني الباحثة لهذا المقياس.

1-تبنت الباحثة في الدراسة الحالية أحد مفاهيم مقياس سيد عثمان حول المسئولية الاجتماعية وهو مفهوم(المشاركة) لذا كان من المناسب تبني هذا المقياس.

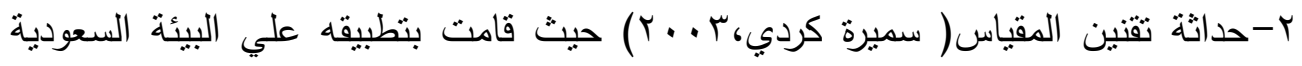
علي عينة مشابهه لعينة الدراسة الحالية وهي(طالبات كلية التربية بالطائف). المعالجة الإحصائية للبيانات: بعد الانتهاء من جهـع بيانات الدراسـة الميدانيـة، تم ترميز البيانات وإدخالها إلبي الحاسب

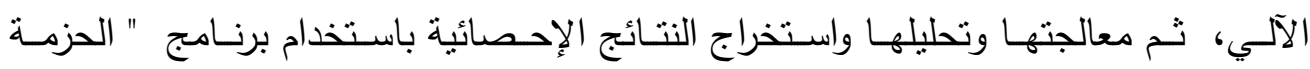

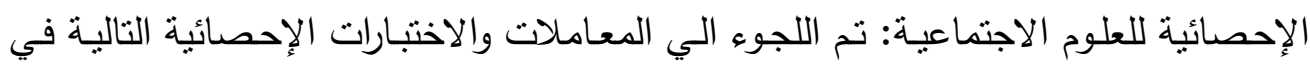
تحليل بيانات الدراسة:

• التكرارات البسيطة والنسب المئوية. • المتوسطات الحسابية والانحرافات المعيارية. • اختبار كاr (Chi Square Test) لدراسـة الدالالة الإحصائية للعلاقة بين متغيرين من المتغيرات الاسمية (Nominal) اختبار (T- Test) لدراسة الدلالة الإحصائية للفروق بين المتوسطات الحسابية لمجموعتين من المبحوثين في أحد متغيرات الفئة أو النسبة (Interval Or Ratio) 
اختبار (z) لدراسة معنوية الفرق بين نسبتين مئويتين ، وقد اعتبرت قيمة z غير دالة إذا

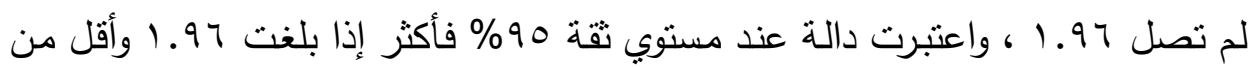

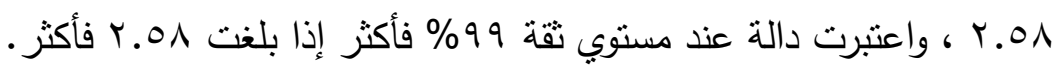
معامل ارتباط بيرسون (PearsonCorrelation Coefficient) لدراسـة شدة واتجاه العلاقة الارتباطية بين متغيرين من مستوى المسافة أو النسبة. تحليل التباين ذو البعد الواحد (Oneway Analysis of Variance) المعروف اختصاراً باسم ANOVA لدراسـة الدلالمة الإحصائية للفروق بين المنوسطات الحسابية لأكثر من مجموعتين من المبحوثين في أحد المتغيرات من نوع المسافة أو النسبة (Interval Or Ratio) . • الاختبارات البعدية ( Post Hoc Tests) بطريقة اقل فرق معنوي ( LeastSignificance Difference)

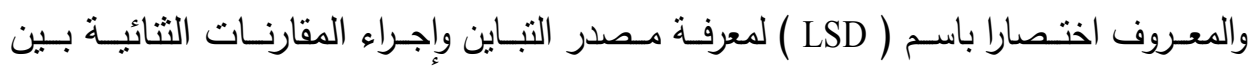
المجموعات التي يثبت ANOVA وجود فروق دالة إحصائيا بينها.

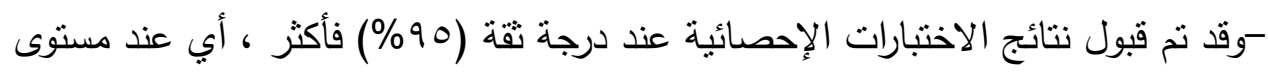

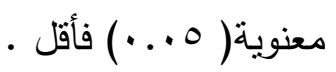

نتائج الاراسة وتحليلها وتفسيرها (أولا) النتائج المتعلقة باستمارة الاستبيان

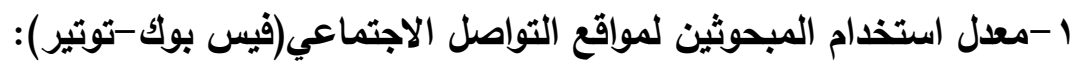
جدول (1)

معدل استخدام المبحوثين لمواقع التواصل الاجتماعي(فيس بوك-توتير) وفقاً للنوع

\begin{tabular}{|c|c|c|c|c|c|c|}
\hline \multicolumn{2}{|c|}{ الإجمالي } & \multicolumn{2}{|c|}{ الإناث } & \multicolumn{2}{|c|}{ الذكور } & \multirow[b]{2}{*}{ معدل الاستخدام } \\
\hline$\%$ & ك5 & $\%$ & ك5 & $\%$ & ك5 & \\
\hline \%^r.. & זTr & $\% \wedge 9 .$. & IVA & $\% \vee \vee .$. & $10 \leqslant$ & دائماً \\
\hline$\%$ \%. . & $\leqslant \wedge$ & $\% \vee .$. & $1 \varepsilon$ & $\%) \vee .$. & $r \varepsilon$ & أحياناً \\
\hline$\% 0_{.}$ & $r$. & $\% \varepsilon$. & $\wedge$ & $\%$ \%.. & Ir & نادراً \\
\hline $1 \ldots$ & $\varepsilon \ldots$ & $1 \ldots$ & r.. & $1 \ldots$ & $r \ldots$ & الإجمالي \\
\hline
\end{tabular}

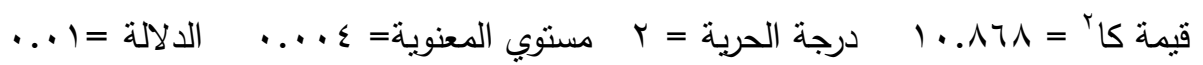


تنبير النتائج التفصيلية للجدول السابق أن نسبة من يستخدمون مواقع التواصل

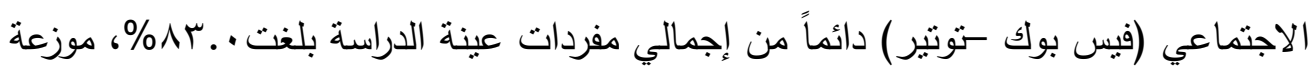

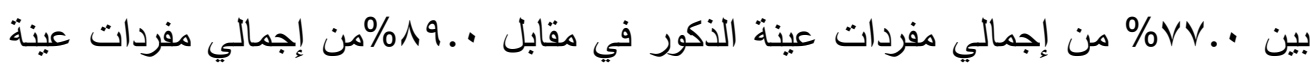
الإناث ، وبلغت نسبة من بيتخدمون مواقع التواصل الاجتماعي (فبس بوك - تونتير) أحياناً

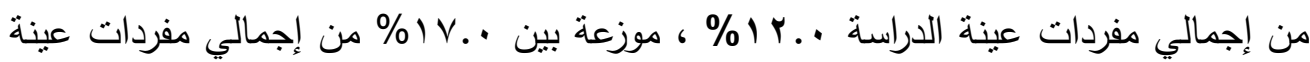

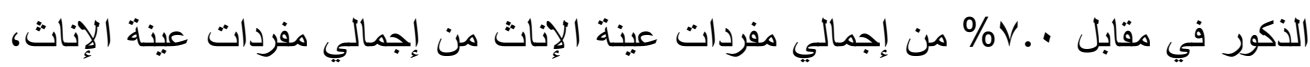

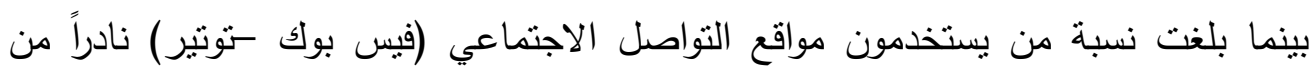

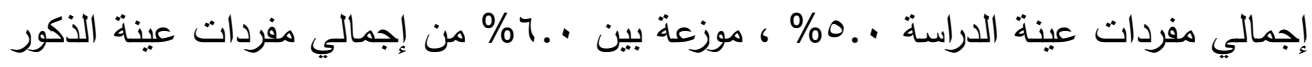
في مقابل •.ء \% من إجمالي مفردات عينة الإناث.

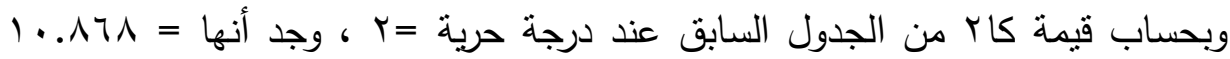

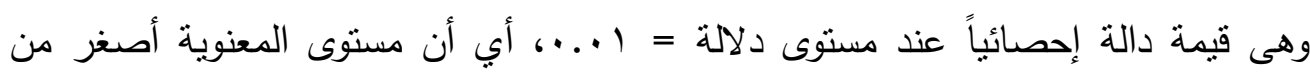

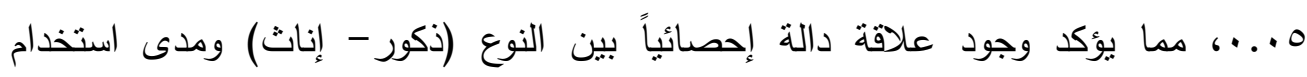
المبحوثين لمواقع التواصل الاجتماعي (فيس بوك كتونتير ). وتثير النتيجة السابقة إلي أن نسبة كبيرة من الثباب الجامعي يستخدمون مواقع

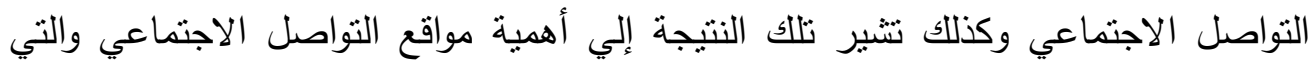
بمكن استخدامها وتوظيفها لخدمة القضايا المجتمعية.

ץ-عدد ساعات استخدام المبحوثين لمواقع التواصل الاجتماعي(فيس بوك -توتير) يومياً:

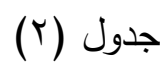

عدد ساعات استخدام المبحوثين لمواقع التواصل الاجتماعي(فيس بوك-توتير) يومياً وفقاً

\begin{tabular}{|c|c|c|c|c|c|c|}
\hline \multicolumn{7}{|c|}{ للنوع } \\
\hline \multicolumn{2}{|c|}{ الإجمالي } & \multicolumn{2}{|c|}{ الإناث } & \multicolumn{2}{|c|}{ الذكور } & \multirow{2}{*}{ عدد الاستخدام } \\
\hline$\%$ & 5 & $\%$ & ك5 & $\%$ & ك & \\
\hline$\% \leqslant 0$. & 11. & $\% \leqslant r .$. & $\Lambda \varepsilon$ & $\% \leqslant \wedge .$. & 97 & أقل من ساعه \\
\hline YV.O & 11. & $r V .$. & $0 \leqslant$ & r^.. & 07 & من ساعه إلي \\
\hline $00 .$. & rr. & $0 \wedge .$. & 117 & or.. & $1 \cdot \varepsilon$ & من "اساعات فأكثر \\
\hline $1 \ldots$ & $\varepsilon \ldots$ & $1 \ldots$ & r.. & $1 \ldots$ & r.. & الإجمالى \\
\hline
\end{tabular}

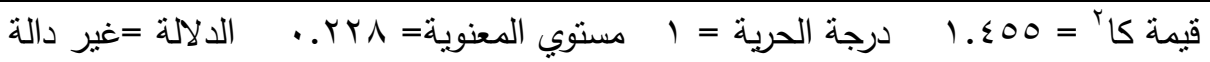


تشير النتائج التقصيلية للجدول السابق أن عدد ساعات استخدام مواقع التواصل

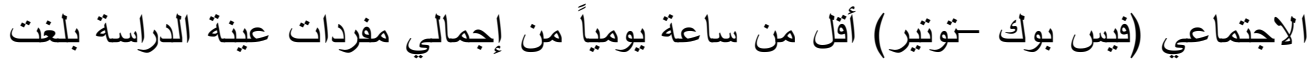

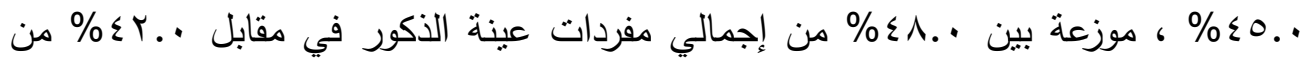

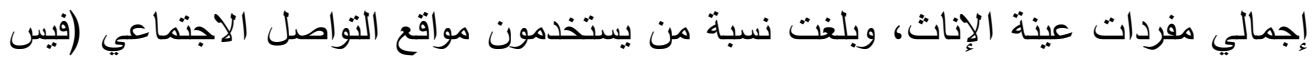

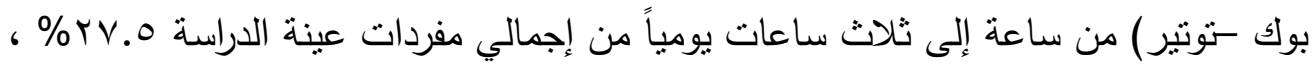

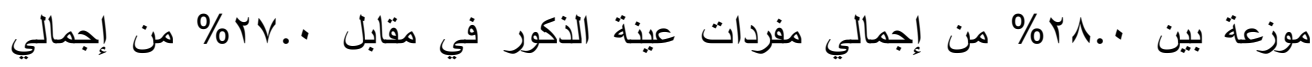
مفردات عينة الإناث. وبلغت نسبة منيستخدمون مواقع التواصل الاجتماعي (فيس بوك كتونير ) من ساساعات

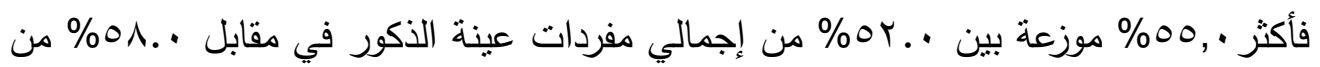
إجمالي مفردات عينة الإناث.

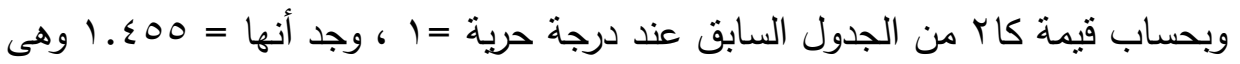

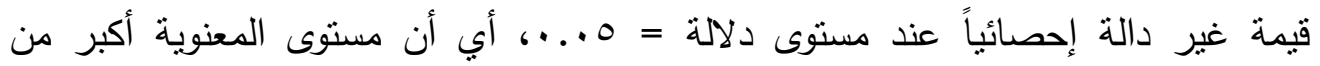

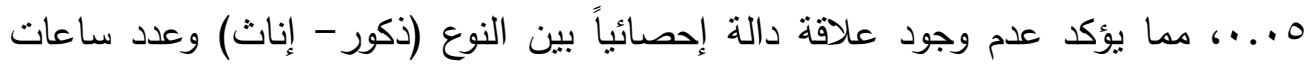

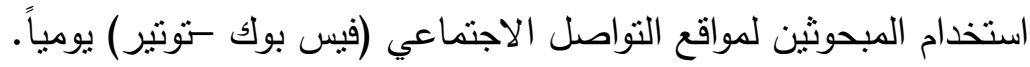

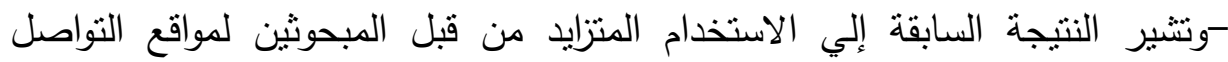

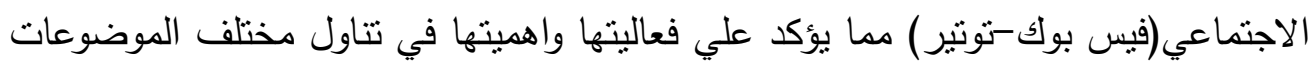
بالنسبة للمبحوثين.

ب-مدى متابعة المبحوثين للقضايا المجتمبة علي مواقع التواصل الاجتماعي(فيس بوك-توتير):

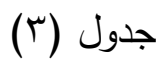

مدى متابعة المبحوثين للقضايا المجتمعية علي مواقع التواصل الاجتماعي(فيس بوك-توتير)

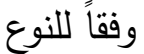

\begin{tabular}{|c|c|c|c|c|c|c|}
\hline \multicolumn{2}{|c|}{ الإجمالي } & \multicolumn{2}{|c|}{ الإناث } & \multicolumn{2}{|c|}{ الذكور } & \multirow{2}{*}{ مدى المتابعة العينة } \\
\hline$\%$ & ك & $\%$ & ك & $\%$ & ك & \\
\hline$\% \leqslant 1 .$. & $17 \varepsilon$ & $\% \leqslant r .0$ & AV & $\%$ \%४.० & VV & دائماً \\
\hline \%ऑ।.. & 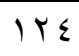 & $\% ץ . .0$ & 71 & $\%$ \% & זיד & أحياناً \\
\hline \%५^.. & 114 & \%үч.. & or & $\% r . .$. & 7. & نادراً \\
\hline $1 \ldots$ & $\varepsilon \ldots$ & $1 \ldots$ & r.. & $1 \ldots$ & r.. & الإجمالي \\
\hline
\end{tabular}

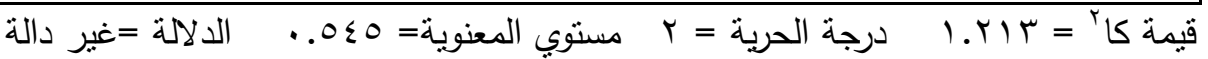

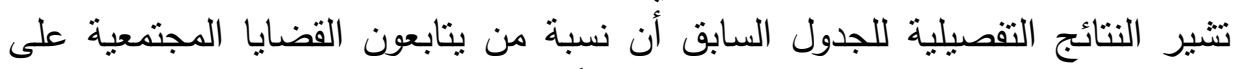

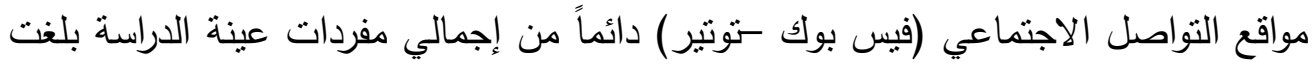

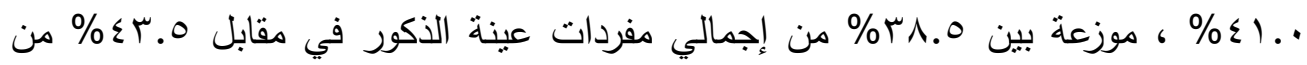




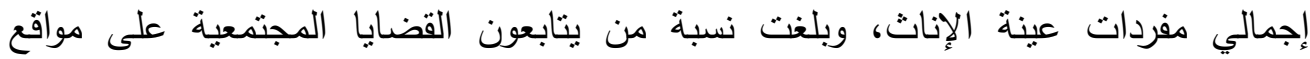

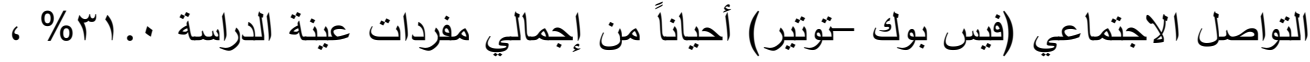

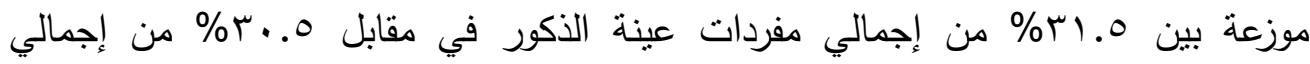

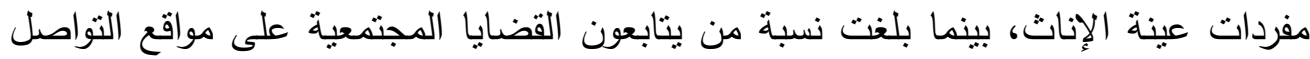

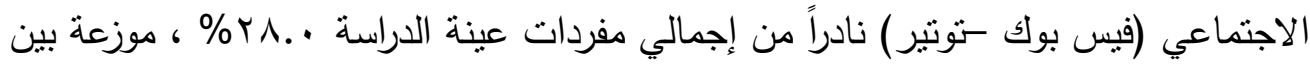

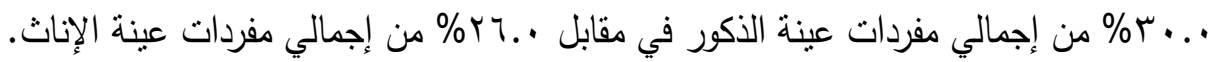

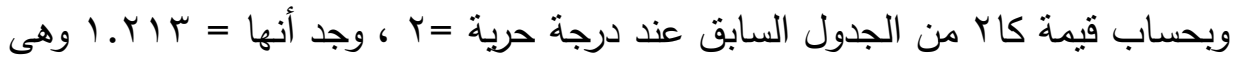

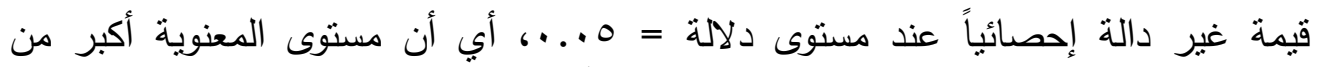

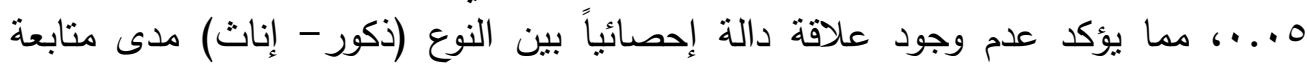

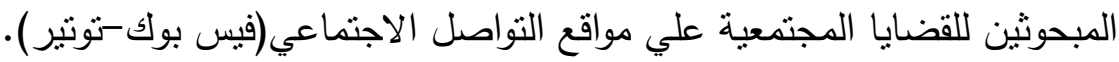

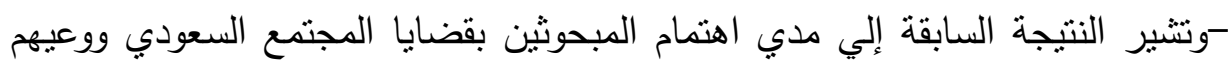

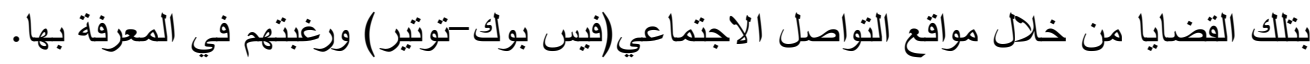

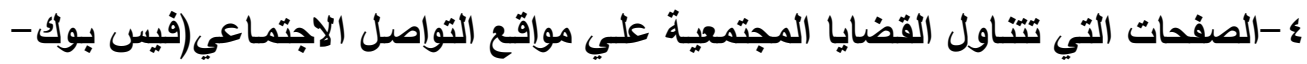

جدول (飞)

توتير) ويشارك بها المبحوثون:

الصفحات التي تتناول القضايا المجتمعية علي مواقع التواصل الاجتماعي( فيس بوك-توتير ) ويشارك بها المبحوثون وفقاً للنوع التواتيا

\begin{tabular}{|c|c|c|c|c|c|c|c|c|}
\hline \multirow{2}{*}{ 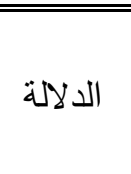 } & \multirow{2}{*}{ 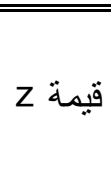 } & \multicolumn{2}{|c|}{ ال الإجمالي } & \multicolumn{2}{|c|}{ الإنا } & \multicolumn{2}{|c|}{ ال الذكور } & \multirow[t]{2}{*}{ 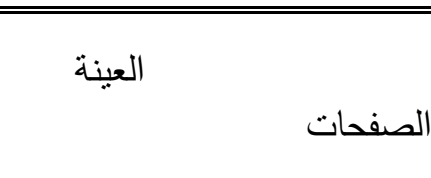 } \\
\hline & & $\%$ & ك & $\%$ & st| & $\%$ & ك5 & \\
\hline غير دالة & $\cdot \varepsilon r$ & 09 & r & 0 & 1 & 7 & 1 & صفحه قضايا سعودية \\
\hline غير دالة &. .77 & ov & r & 7 & 1 & 0 & 1 & صفحه قضايا اجتماعيه وتربوية \\
\hline$\ldots 0$ & r... & $\leqslant 7$ & 1 & $r$ & $\mathrm{~V}$ & 0 & 1 & صفحة قضايا المجتمع السعودي \\
\hline 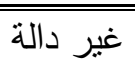 & $1 . r r^{2}$ & $\varepsilon$. & 1 & $\varepsilon$ & $\Lambda$ & $r$ & V & صفحة قضايا فتبات سعوديات \\
\hline غير دالة & 1.11 & 0. & r & $\wedge$ & 1 & $r$ & 7 & أخري \\
\hline & & & & r. & 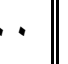 & $r$. & & جملة من سئلوا \\
\hline
\end{tabular}

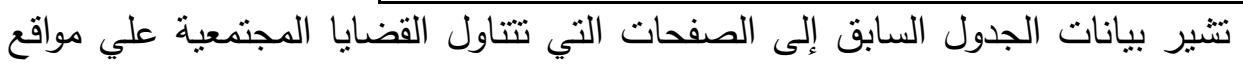

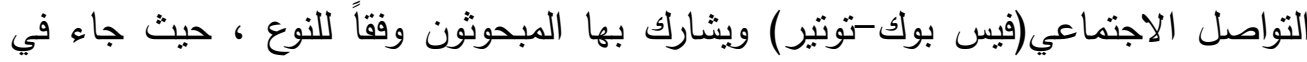

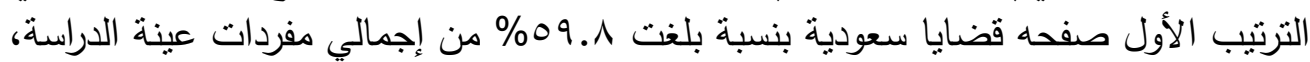

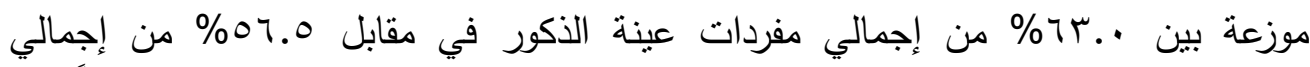
مفردات عينة الإناث، وتتقارب النسبتان، حيث إن الفارق بين النسبتين غير دال إلى إحصائياً، فقد 


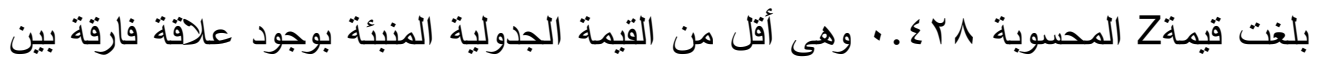
النسبتين بمستوى ثقة 90 \%

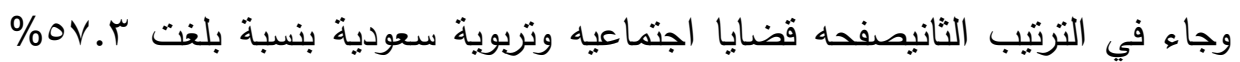

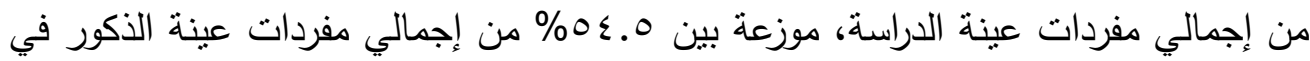

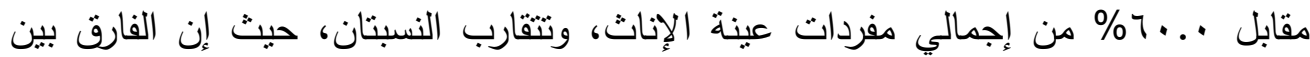

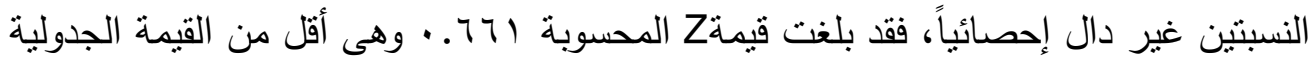
المنبئة بوجود علاقة فارقة بين النسبتين بمستوى ثقة 90 \%

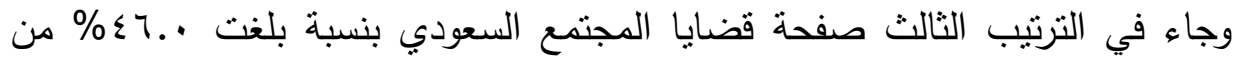

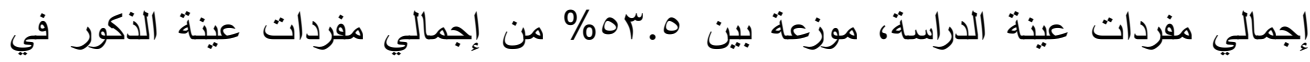

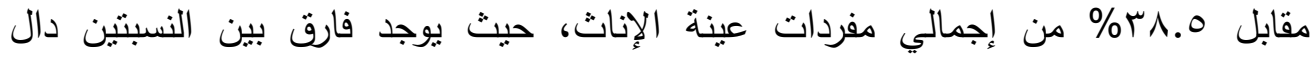

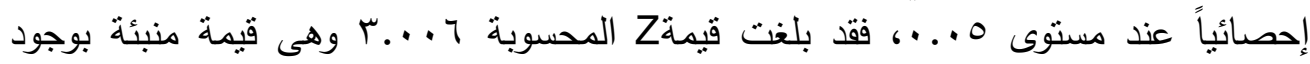
علاقة فارقة بين النسبتين بمستوى ثقة 90\%

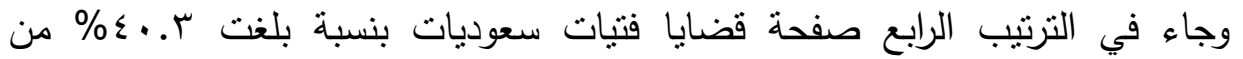

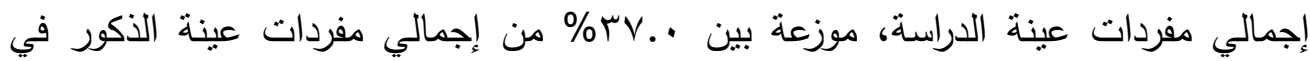

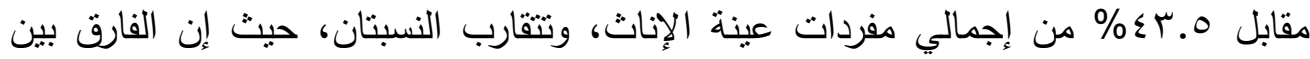

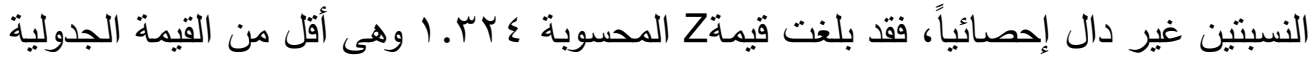

المنبئة بوجود علاقة فارقة بين النسبتين بمستوى ثقة 90\%

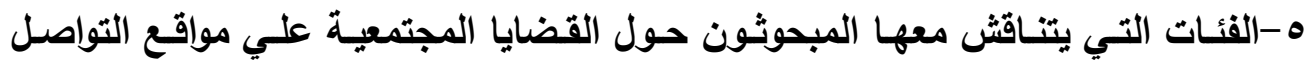
الاجتماعي (فيس بوك-توتير):

جدول (0)

الفئات التي يتتاقش معها المبحوثون حول القضايا المجتمعية علي مواقع التواصل الاجتماعي

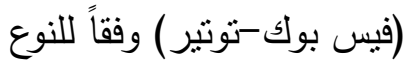

\begin{tabular}{|c|c|c|c|c|c|c|c|c|}
\hline \multirow{2}{*}{ الدلالة } & \multirow{2}{*}{ قيمة z } & \multicolumn{2}{|c|}{ الإجمالي } & \multicolumn{2}{|c|}{ الإناث } & \multicolumn{2}{|c|}{ الذكور } & \\
\hline & & $\%$ & ك5 & $\%$ & ك5 & $\%$ & كs & \\
\hline غير دالة & $.97 \varepsilon$ & $\% \wedge 1 . \wedge$ & TrV & $\% \wedge$ \%.. & 177 & $\% \wedge . .0$ & 171 & الأصدقاء \\
\hline غبر دالة & $.0 \leqslant \leqslant$ & $\% \leq q . r$ & $19 V$ & $\% \leq 9.0$ & 99 & $\% \leq 9$. & 91 & الأسرة \\
\hline غير دالة & $.7 \leq 7$ & \%r. r & $|r|$ & $\%$ \% & זד & $\%$ \%.. & $0 \Lambda$ & الزملاء \\
\hline \multirow[t]{2}{*}{. .0} & T.rIT & $\%$ \%^.r & $11 \pi$ & \%rr.. & $\leqslant 7$ & \% \% & $T V$ & أشخاص جدد \\
\hline & & \multicolumn{2}{|c|}{$\varepsilon \ldots$} & \multicolumn{2}{|c|}{$r \ldots$} & \multicolumn{2}{|c|}{ r.. } & جملة من \\
\hline
\end{tabular}

تشير بيانات الجدول السابق إلى الفئات التي يتتاقش معها المبحوثون حول القضايا

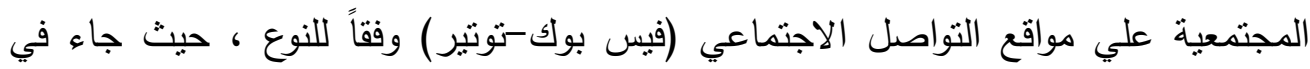


الترتيب الأول الأصدقاء المقربين بنسبة بلغت ^ــ1\% من إجمالي مفردات عينة الدراسة،

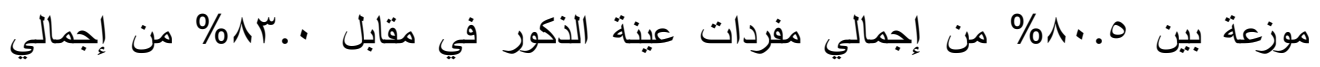
مفردات عينة الإناث، وتثقارب النسبتان، حيث إن الفارق بين النسبتين غير دال إحصائياً، فقد

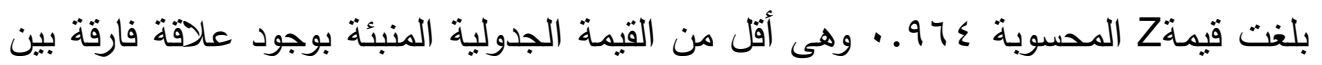
النسبتين بمستوى ثقة 90 \%. وجاء في الترتيب الثانيالأسرة بنسبة بلغت ؟.9 ٪\% من إجمالي مفردات عينة الدراسة،

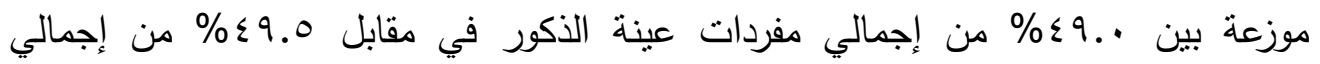
مفردات عينة الإناث، وتتقارب النسبتان، حيث إن الفارق بين النسبتين غير دال إحصائياً، فقد بلغت قيمةZ المحسوبة §؟0. . وهى أقل من القيمة الجدولية المنبئة بوجود علاقة فارقة بين النسبتين بمستوى ثقة 90\% وجاء في الترنيب الثالث الزملاء بنسبة بلغت r.ب٪\% من إجمالي مفردات عينة

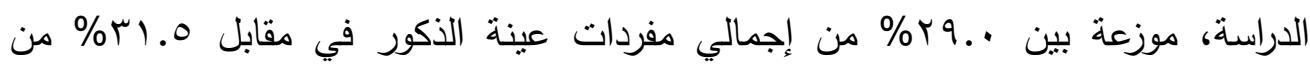
إجمالي مفردات عينة الإناث، وتتقارب النسبتان، حيث إن الفارق بين النسبتين غير دال

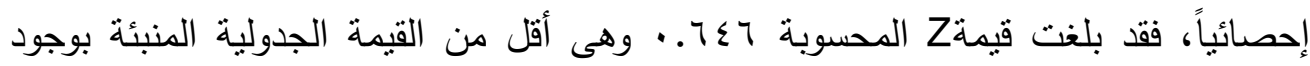
علاقة فارقة بين النسبتنين بمستوى ثقة 90\%

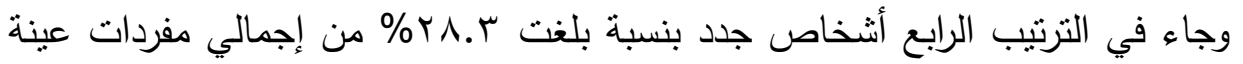

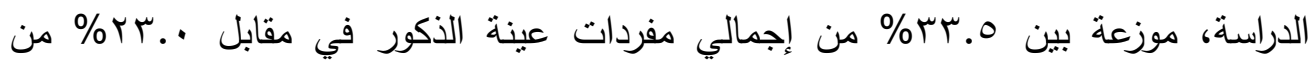

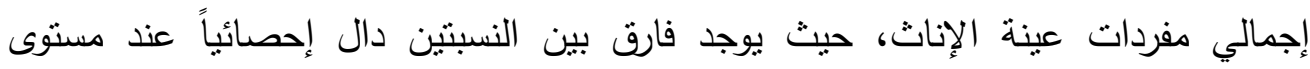

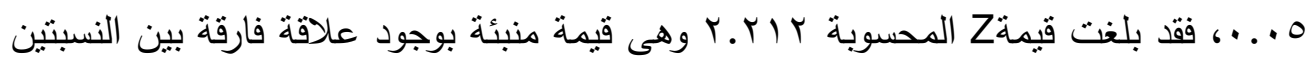
بمستوى ثقة 90\%.

-وقد ترجع النتيجة السابقة ووجود الاصدقاء المقربين في مقدمة الفئات التي يتناقش معها المبحوثون حول القضايا المجتمعية علي مواقع التواصل الاجتماعي إلي أن الأصدقاء

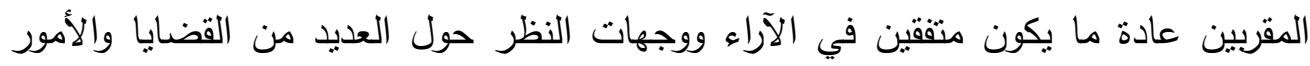
علي عكس الأشخاص الجدد والتي جاءت في المرتبة الأخيرةحيث قد لا يكون للمبحوثين علاقة قويه بهم أو يتوافقوا معهم في الرأي مما يشكل صعوبة في التواصل بينهم بشكل سربع وفي وقت قصير فالوصول إلي نقطة اتفاق بينهم قد تأخذ فترة طويلة وقد لا يتم الاتفاق. 
צ-أكثر القضايا المجتمعية انتشاراً علي مواقع التواصل الاجتماعي (فيس بوك-توتير) من وجهة نظر المبحوثين: ائن

جدول (7)

أكثر القضايا المجتمعية انتشاراً علي مواقع التواصل الاجتماعي (فيس بوك-ثوتير ) من وجهة

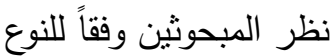

\begin{tabular}{|c|c|c|c|c|c|c|c|c|}
\hline \multirow{2}{*}{ 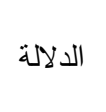 } & \multirow{2}{*}{ قيمة z } & \multicolumn{2}{|c|}{ الإجمالي } & \multicolumn{2}{|c|}{ ال الإناث } & \multicolumn{2}{|c|}{ الذكور } & \\
\hline & & $\%$ & ك5 & $\%$ & ك & $\%$ & ك & \\
\hline$\ldots 0$ & r.r.Tq & $\% \wedge 1 . \wedge$ & rTV & $\% \wedge \wedge$. . & $1 V 7$ & $\% \vee 0.0$ & 101 & قضايا ارتقاع تكاليف المعيشة \\
\hline غير دالة & $.0 \leqslant \leqslant$ & $\% 79.1$ & rVq & $\%$ \%४.० & ITV & $\% \vee 1 .$. & $1 \leqslant r$ & قضايا العنف الأسري \\
\hline$\ldots 0$ & r. .79V & \%TV.r & ץ & $\% \vee r .0$ & $1 \leqslant V$ & $\% 7 \cdot . \wedge$ & $|r|$ & قضايا الرشوة \\
\hline غير دالة & $1 . r 0$. & $\%$ \%ร.А & roq & $\% 71.0$ & IrT & $\% \curlyvee \wedge$. & 147 & قضايا الغش \\
\hline غير دالة & .71 . & $\%$ rv.. & $1 \cdot 1$ & $\%$ \%... & 7. & $\% r \leq .$. & $\varepsilon \wedge$ & قضايا المحسوبية \\
\hline غير دالة & $. . \leq 7 \leq$ & $\%$ \% & 91 & $\%$ \%r.o & $\varepsilon V$ & $\%$ Y 0.0 & 01 & قضايا الطلاق \\
\hline غير دالة & 1.509 & $\%$ \%.r. & 10 & \%rr.o & $\leq 0$ & $\% r . .$. & $\varepsilon$. & قضايا التفحيط والتهور في \\
\hline & & $\varepsilon$. & & r & & r & & جملة من سئلوا \\
\hline
\end{tabular}

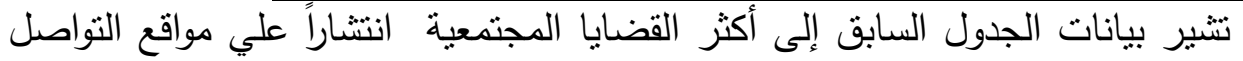

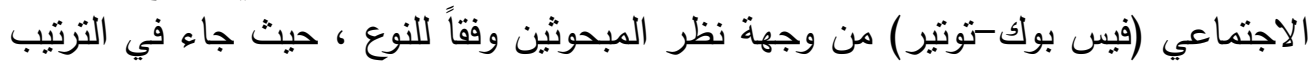

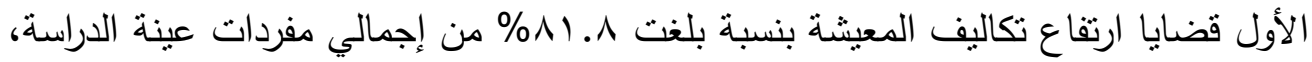

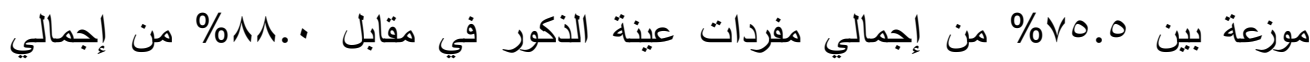

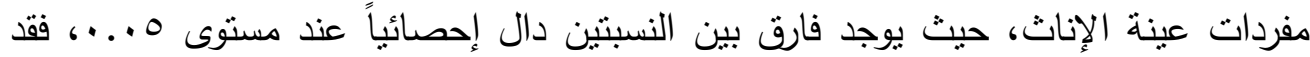

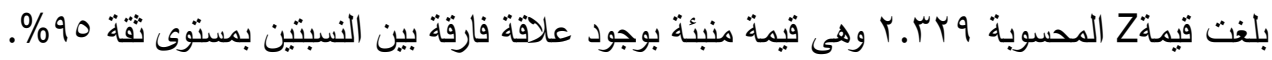

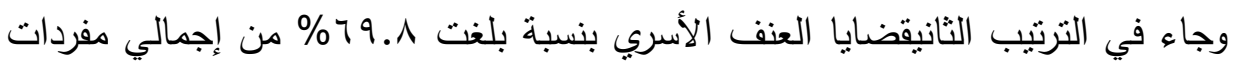

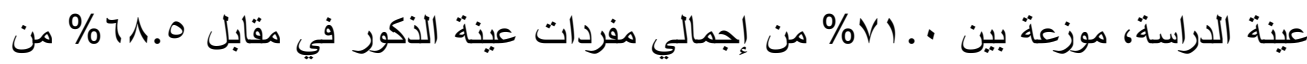

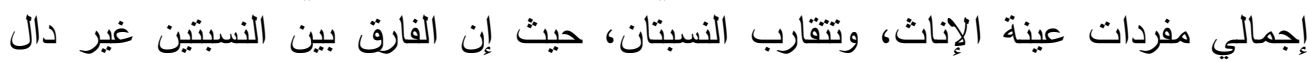

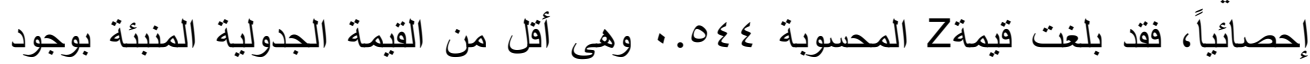
علاقة فارقة بين النسبتين بمستوى ثقة 90 \%

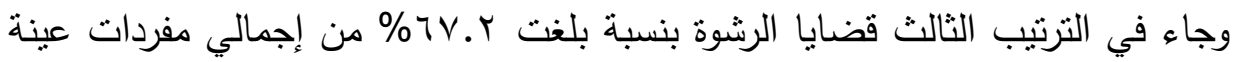

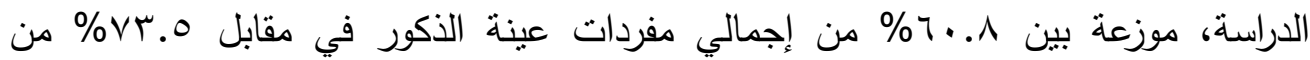

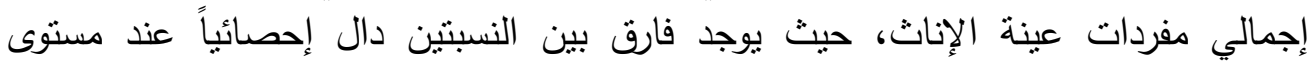

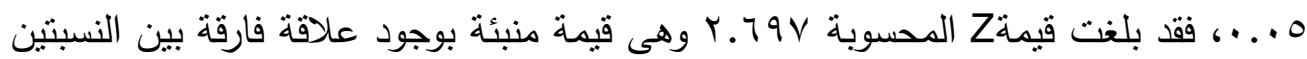
بمستوى ثقة 90\%

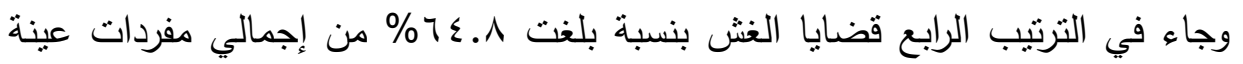

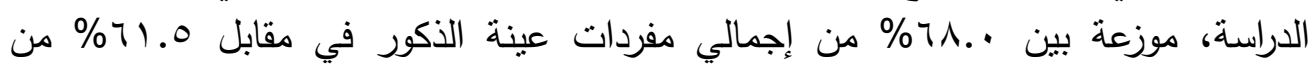


إجمالي مفردات عينة الإناث، وتتقارب النسبتان، حيث إن الفارق بين النسبتين غير دال

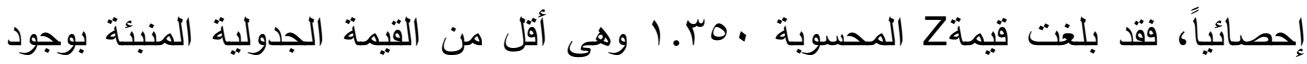
علاقة فارقة بين النسبتين بمستوى ثقة 90\%

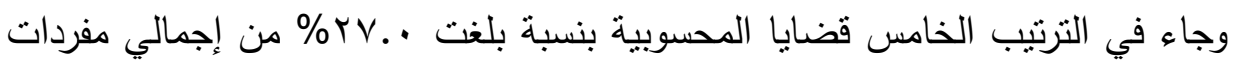

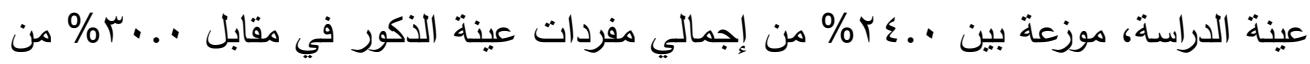

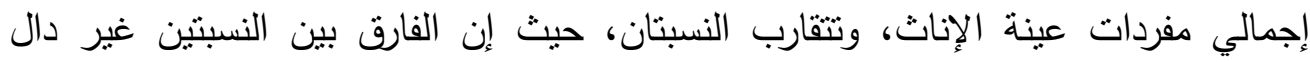

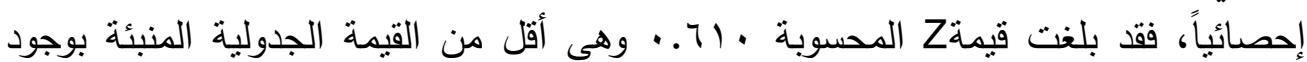
علاقة فارقة بين النسبتين بمستوى ثقة 90 \%

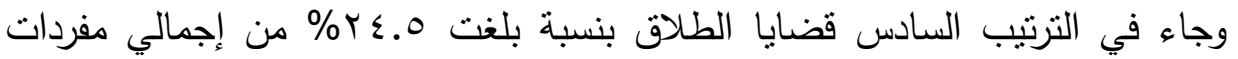

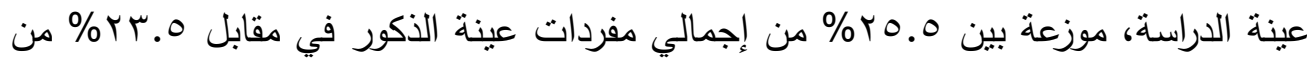

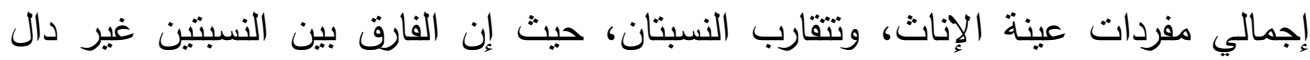

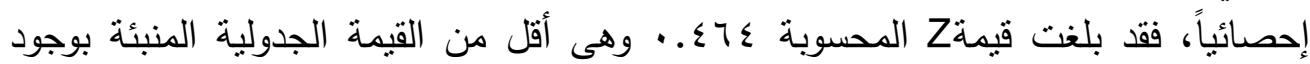
علاقة فارقة بين النسبتين بمستوى ثقة 90\%.

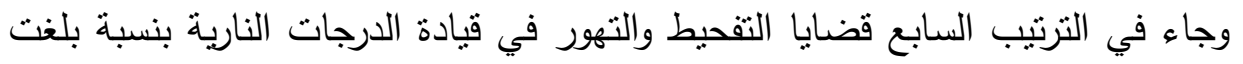

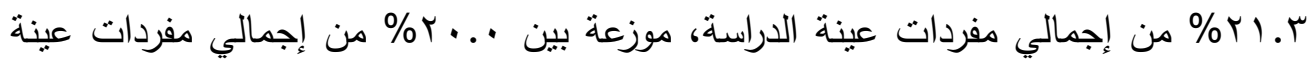

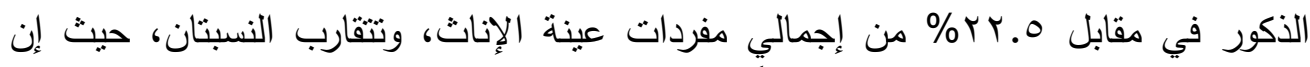

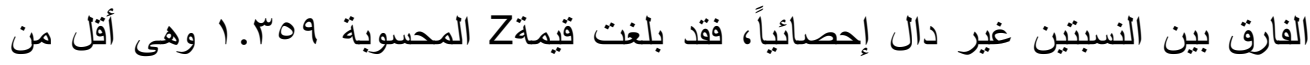

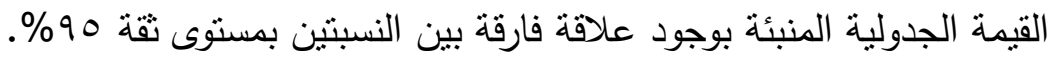

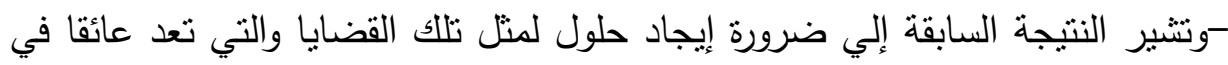
سبيل تحقيق التتمية المستدامة في المجتمع السعودي.

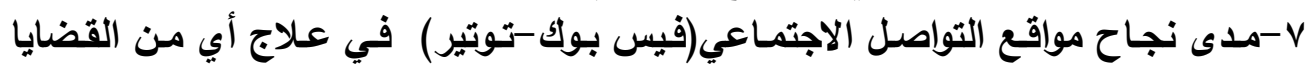
المجتمعية من وجهة نظر المبحوثين: جدول (v)

مدى نجاح مواقع التواصل الاجتماعي(فيس بوك-توتير ) في علاج أي من القضايا

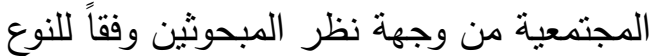

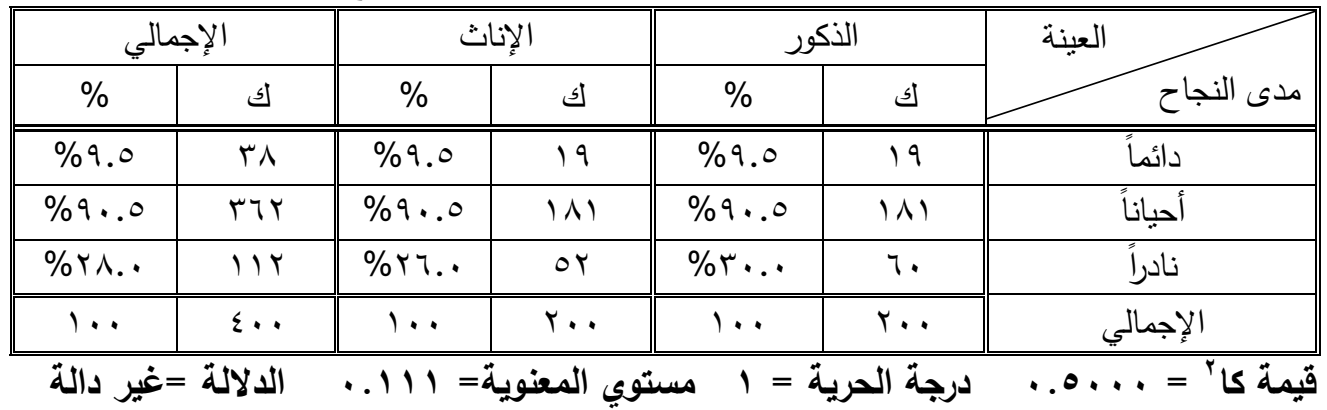


تشير النتائج التفيلية للجدول السابق أن نسبة من برون أن مواقع التواصل الاجتماعي(فيس بوك-توتير) نتجح دائماً في علاج أبي من القضايا المجتمعية من إجمالي فئي

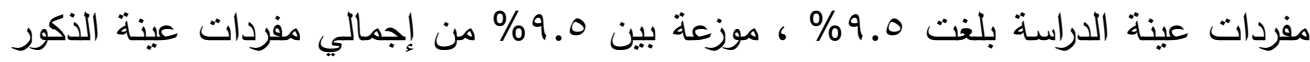

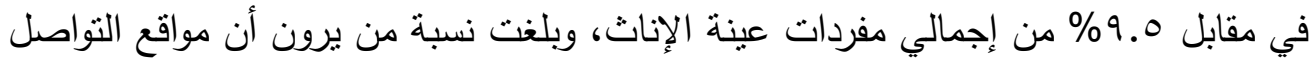

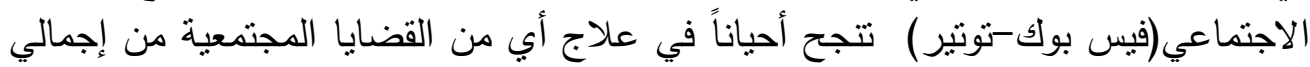

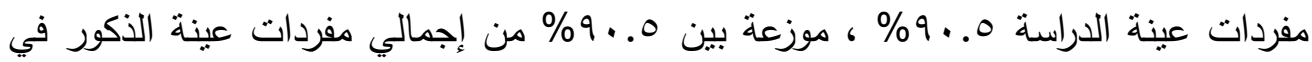

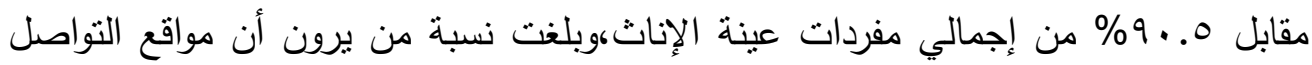

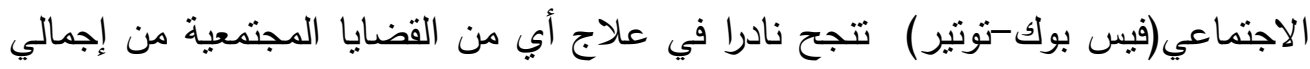

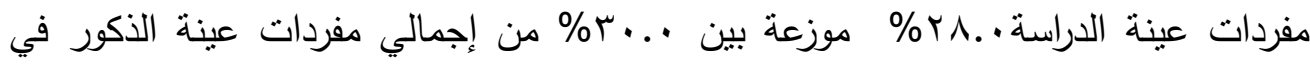

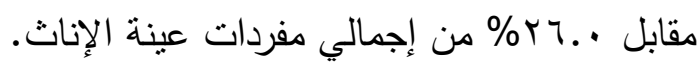

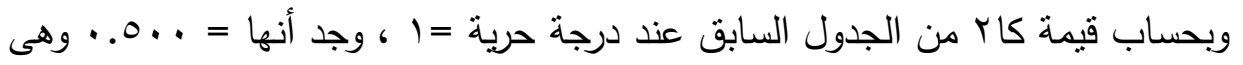

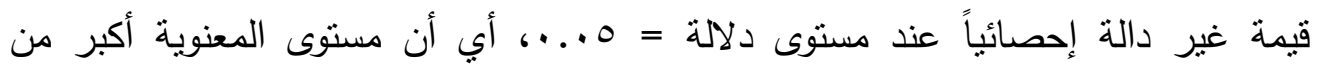

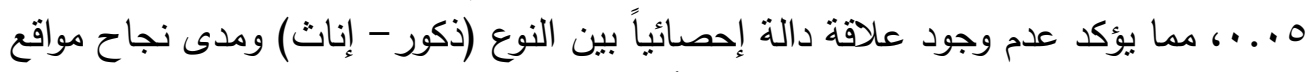

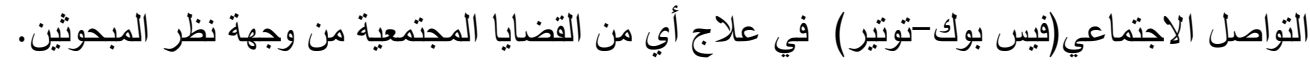

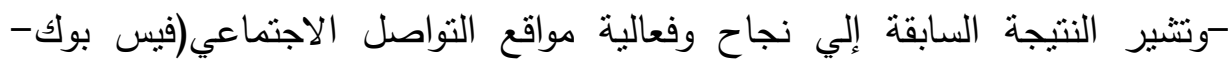

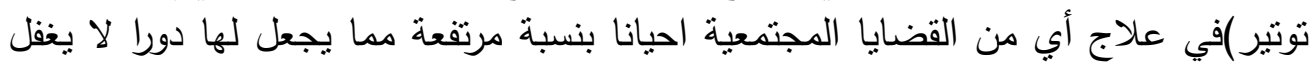

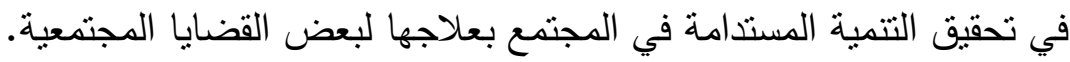

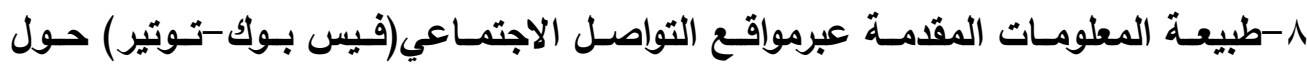
القضايا المجتمعية من وجهة نظر المبحوثين: جدول (^)

طبيعة المعلومات المقدمة عبرمواقع التواصل الاجتماعي(فيس بوك-توتير ) حول القضايا

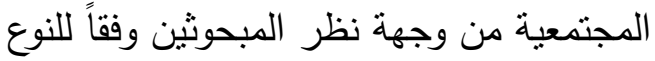

\begin{tabular}{|c|c|c|c|c|c|c|}
\hline \multicolumn{2}{|c|}{ الإجمالي } & \multicolumn{2}{|c|}{ الإناث } & \multicolumn{2}{|c|}{ الذكور } & العينة \\
\hline$\%$ & ك & $\%$ & ك & $\%$ & ك & - \\
\hline$\% r \cdot . \wedge$ & $\Delta r$ & $\% 19.0$ & rq & \%rr.. & $\varepsilon \varepsilon$ & هادفة \\
\hline$\% \circ \wedge .0$ & $T T \varepsilon$ & $\% 09.0$ & 119 & $\% \circ \vee .0$ & 110 & حديثة \\
\hline$\% r \cdot . \wedge$ & Nז & \%r।.. & $\varepsilon r$ & $\% r \cdot .0$ & \&1 & سطحية \\
\hline $1 \ldots$ & $\varepsilon \ldots$ & $1 \ldots$ & r.. & $1 \ldots$ & r.. & الإجمالى \\
\hline
\end{tabular}

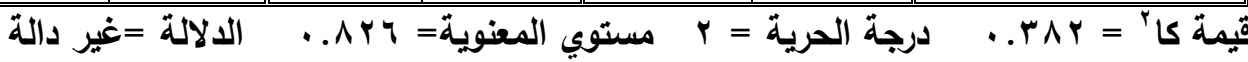

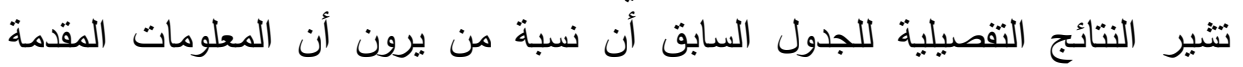

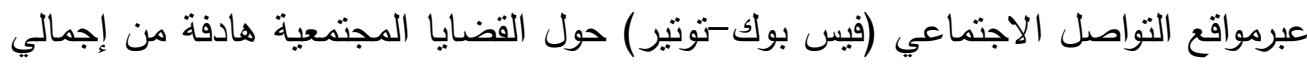

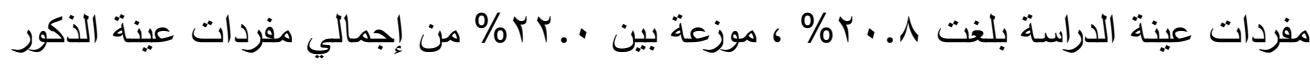

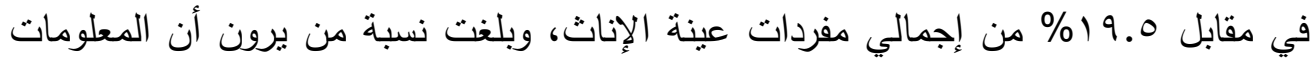




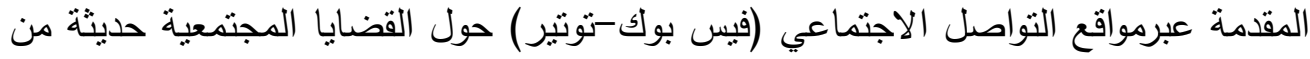

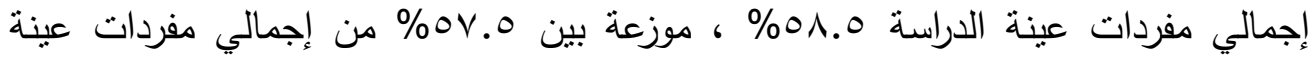

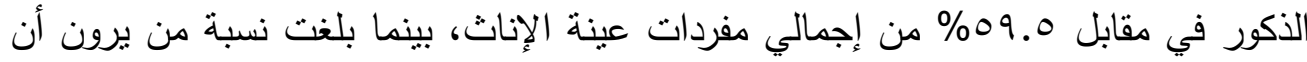

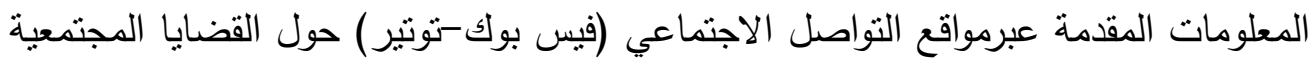

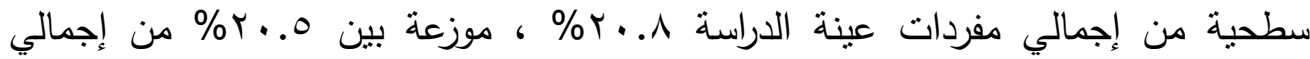

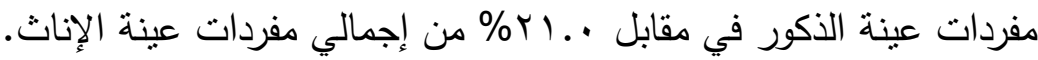

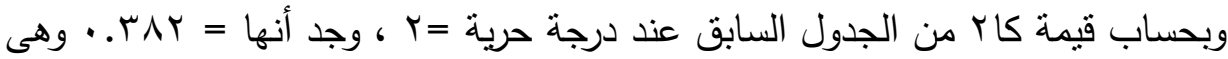

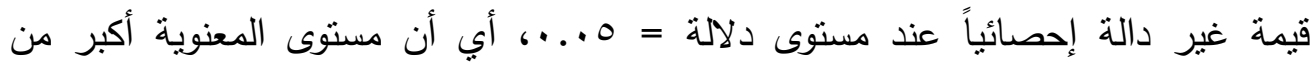

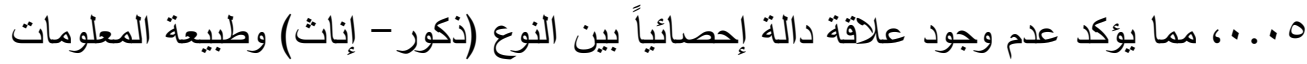

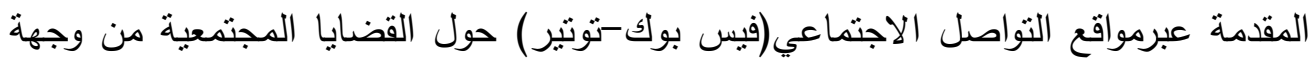

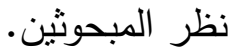
ووتثير النتيجة السابقة إلي تقديم مواقع النواصل الاجتماعي للمعلومات الحديثة حول

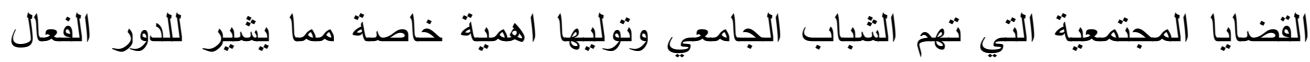
لمواقع التواصل الاجتماعي في تقديم المعلومات الحديثة دائما فيما يتعلق بالقضايا المجتمعية

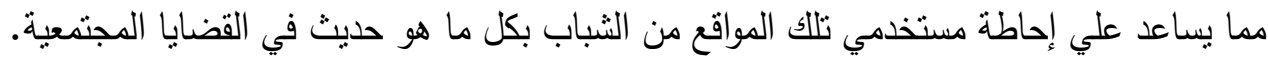

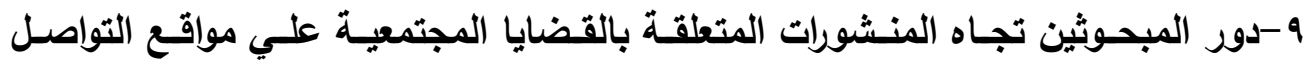
الاجتماعي(فيس بوك -توتير):

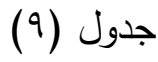

دور المبحوثين تجاه المنشورات المتعلقة بالقضايا المجتمعية علي مواقع التواصل

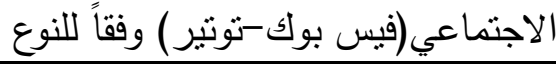

\begin{tabular}{|c|c|c|c|c|c|c|c|c|}
\hline \multirow{2}{*}{ الالالة الد } & \multirow{2}{*}{ قيمة z } & \multicolumn{2}{|c|}{ الإجمالي } & \multicolumn{2}{|c|}{ الإناث } & \multicolumn{2}{|c|}{ الذكور } & \multirow[t]{2}{*}{ العينة } \\
\hline & & $\%$ & ك & $\%$ & ك & $\%$ & ك & \\
\hline غير دالة & $1 . \wedge \Lambda \varepsilon$ & A1.. & rrs & $\% \wedge .$. & 19. & $\% \wedge$ \%. $_{\text {. }}$ & $17 \varepsilon$ & like" أسجل إعجابي بها \\
\hline غير دالة & $.7 \ldots$ & $v \cdot . \cdot$ & $r \wedge$. & $\% 79.0$ & 119 & $\% \vee . .0$ & $1 \leqslant 1$ & أعلق عليها comment" \\
\hline$\ldots 0$ & T.rms & ro.r & $1 \leqslant 1$ & $\%$ \%.॰ & vV & \%rr.. & $7 \varepsilon$ & أستفيد منها ولا أشدارك \\
\hline غير دالة & $.0 \leqslant 0$ & $\begin{array}{c}\text { rY.^ } \\
\%\end{array}$ & $|r|$ & $\%$ \%ч.० & or & $\%$ \% ৭.r & $\vee \wedge$ & 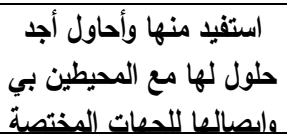 \\
\hline غير دالة & $. .0 V \leqslant$ & $\begin{array}{l}r \wedge . \cdot \\
\%\end{array}$ & $11 r$ & $\%$ rv.. & 0 \& & $\%$ \% q.. & $0 \wedge$ & أخبر بها أصدقائي ومعارفي \\
\hline غير دالة & .r... & Ir.. & $\{\wedge$ & $\%$ १r.. & $r \varepsilon$ & $\% \backslash$ Y.. & $r \xi$ & "share امررها للآخرين \\
\hline غير دالة & .ror & $\%$ & $r$ & $\%$ & 1 & $\%$. & 1 & أخري \\
\hline & & \multicolumn{2}{|c|}{$\ldots$} & \multicolumn{2}{|c|}{ r.. } & \multicolumn{2}{|c|}{ r... } & جملة من سئلوا \\
\hline
\end{tabular}


تشير بيانات الجدول السابق إلى دور المبحوثين تجاه المنشورات المتعلقة بالقضايا

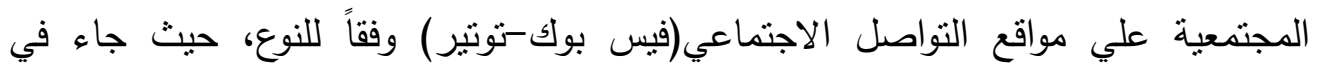

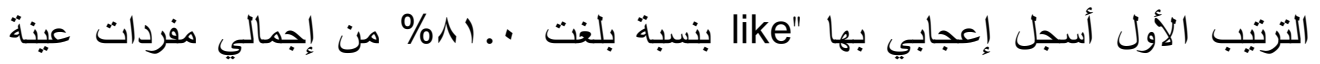

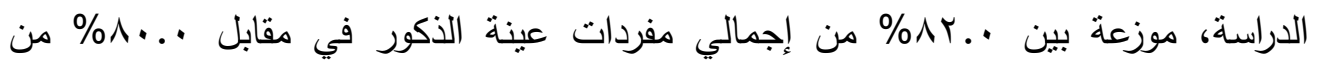

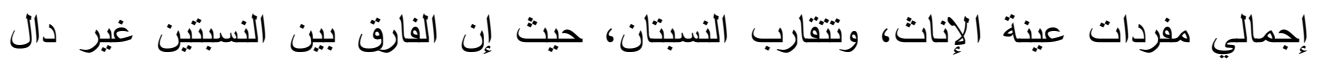

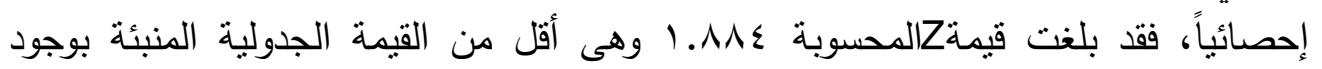

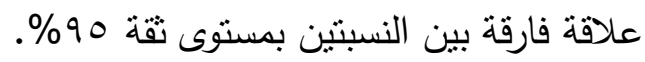

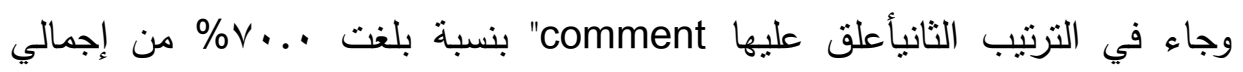

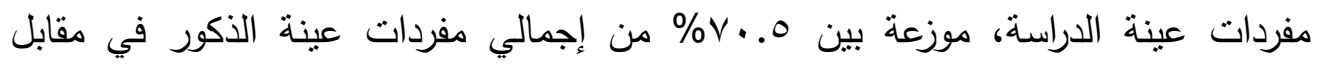

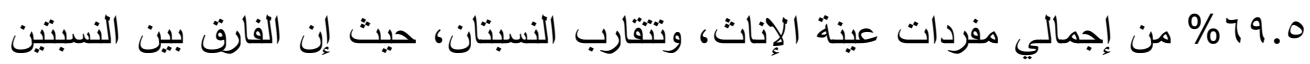

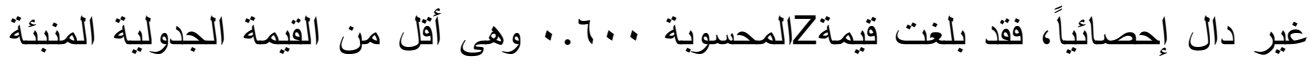
بوجود علاقة فارقة بين النسبتنين بمستوى ثقة 90 \%

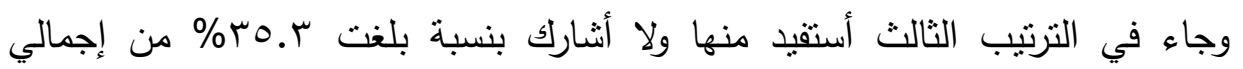

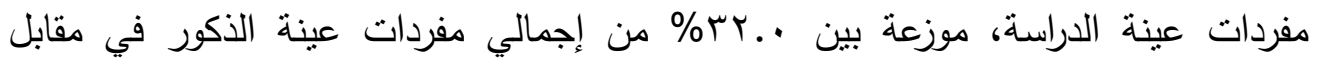

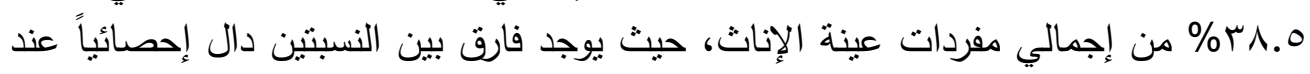

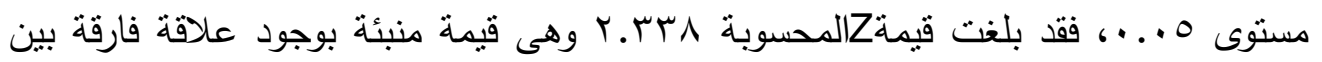

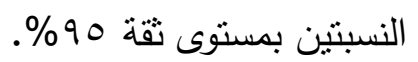
وجاء في الترتيب الرابع استقيد منها وأحاول أجد حلول لها مع المحيطين بي وإيصالها

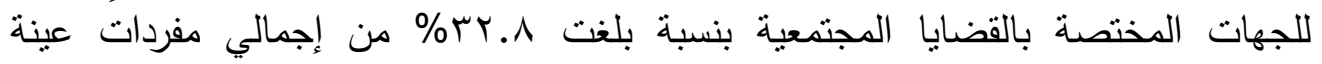

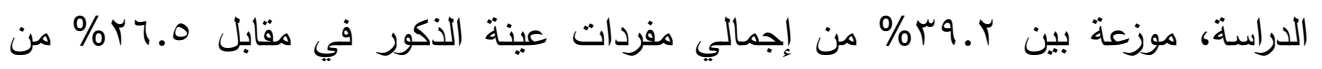

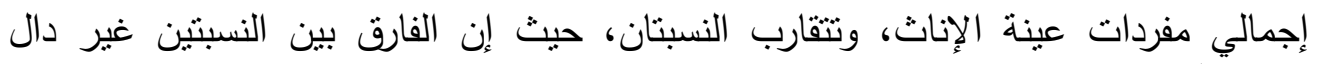

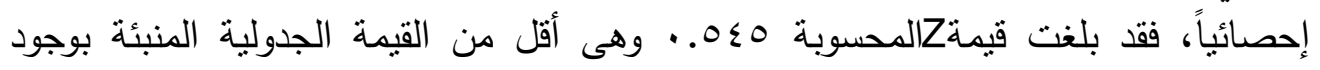

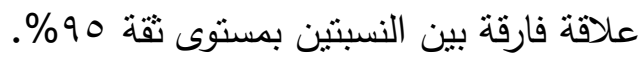
وجاء في الترتيب الخامس أخبر بها أصدقائي ومعارفي خارج نطاق هار الأنترنت بنسبة

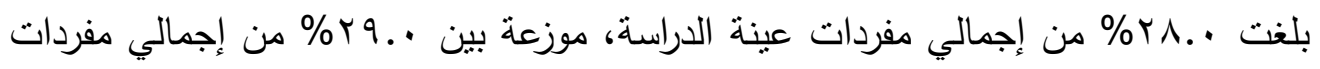

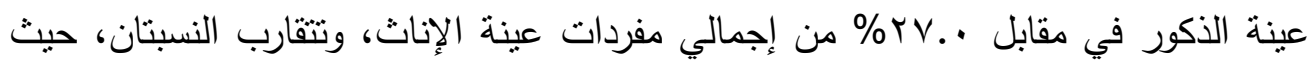

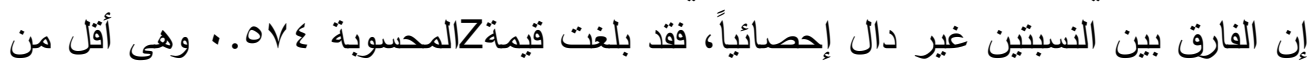

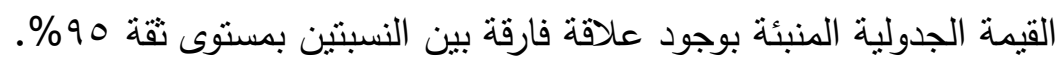

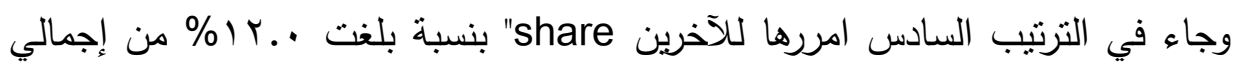

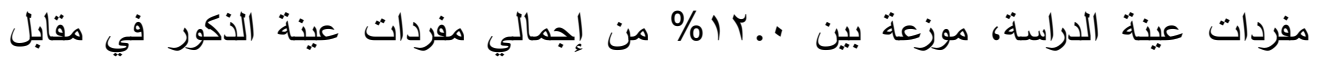

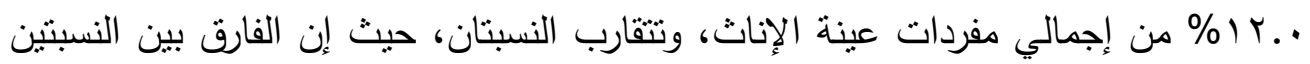


غير دال إحصائياً، فقد بلغت قيمةZالمحسوبة . . ؟.. . وهى أقل من القيمة الجدولية المنبئة

بوجود علاقة فارقة بين النسبتين بمستوى ثقة 90\%

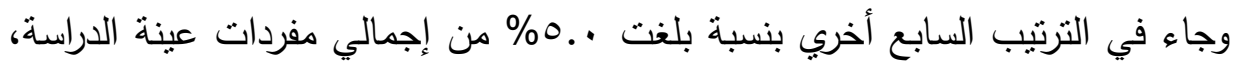

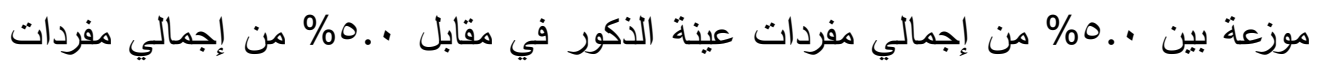

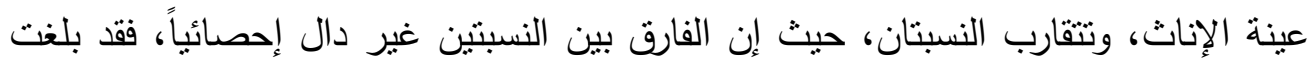

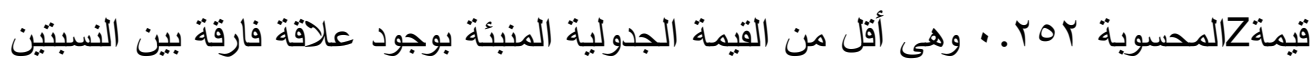
بمستوى ثقة 90\%.

-تثير النتيجة السابقة إلي مدي تفاعلالمبحوثين مع القضايا المجتمعية المتاحة عبر

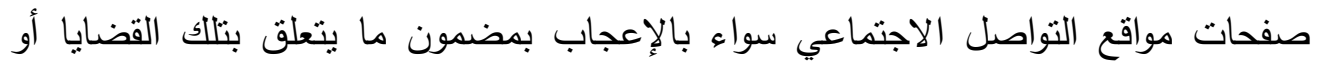
التعليق عليها حيث جاءتا في الترتيب الاول والثاني.

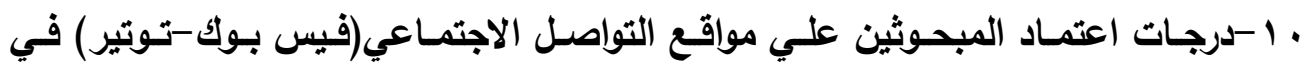
الحصول علي المعلومات حول القضايا المجتمعية: جدول (1.)

درجات اعتماد المبحوثين علي مواقع التواصل الاجتماعي(فيس بوك-توتير) في الحصول

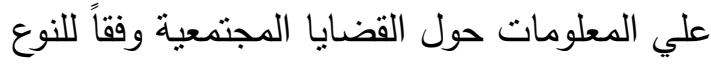

\begin{tabular}{|c|c|c|c|c|c|c|}
\hline \multicolumn{2}{|c|}{ الإجمالي } & \multicolumn{2}{|c|}{ الإناث } & \multicolumn{2}{|c|}{ الذكور } & العينة \\
\hline$\%$ & 5 & $\%$ & ك & $\%$ & ك5 & \\
\hline$\% \backslash$ १.० & $0 \leqslant$ & $\%$ \%ाт.• & T & $\% \backslash \leq .$. & rA & بدرجة كبيرة \\
\hline$\% \circ \cdot . \wedge$ & $r \cdot r$ & $\% 01.0$ & $1 \cdot r$ & $\% \circ .$. & $1 \ldots$ & بدرجة متوسطة \\
\hline$\%$ \%०.A & $1 \leqslant r$ & $\%$ \% 0.0 & V) & \%чт.. & VY & بدرجة منخفضة \\
\hline $1 \cdots$ & $\varepsilon \ldots$ & $1 \cdots$ & r.. & $1 \ldots$ & r.. & الإجمالي \\
\hline
\end{tabular}

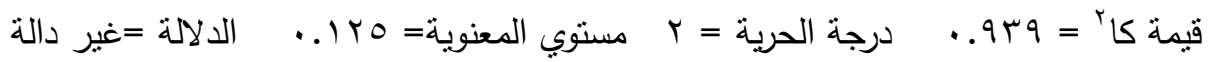

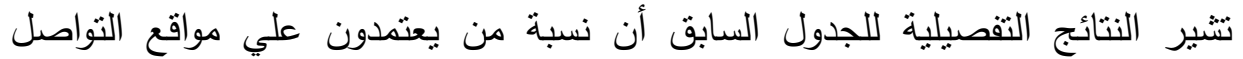

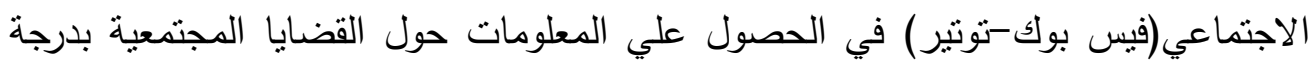

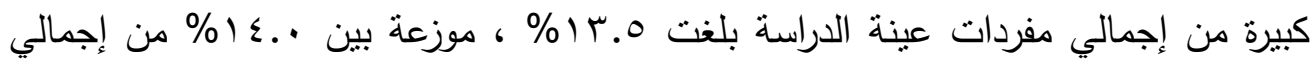

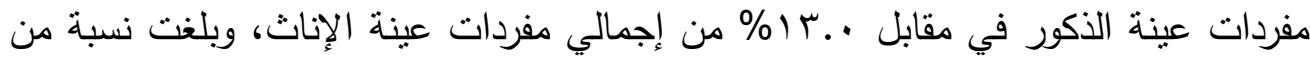

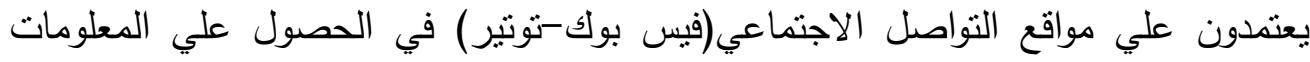

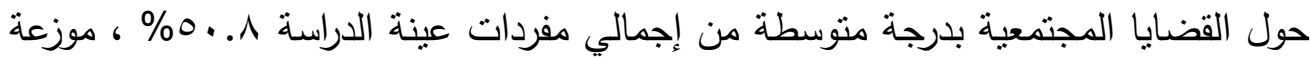

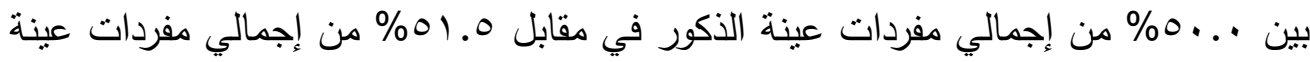

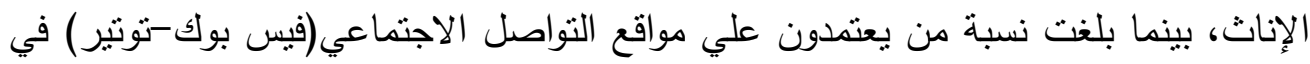


الحصول علي المعلومات حول القضايا المجتمعية بدرجة منخفضة من إجمالي مفردات عينة

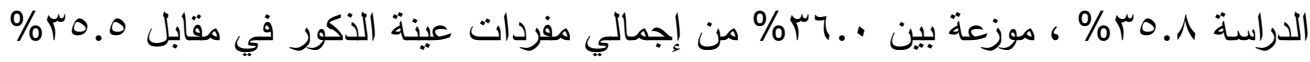
من إجمالي مفردات عينة الإناث.

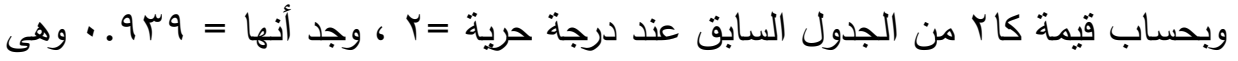

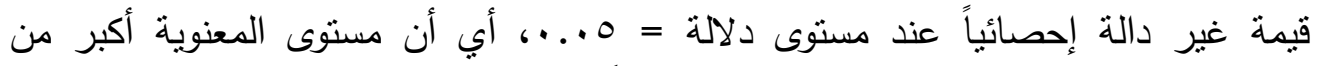

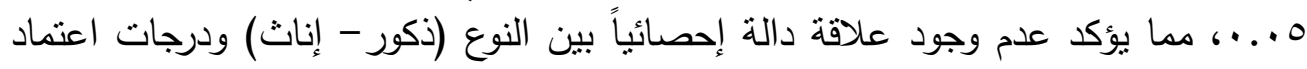

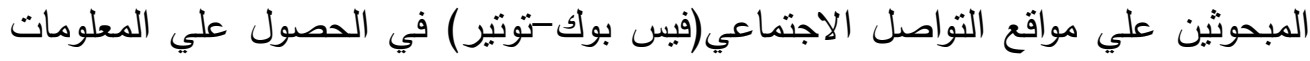
حول القضايا المجتمعية. -وقد ترجع النتيجة السابقة واعتماد المبحوثين بدرجة منوسطة علي مواقع التواصل

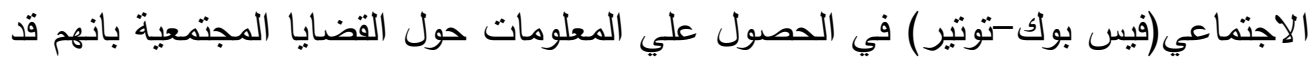

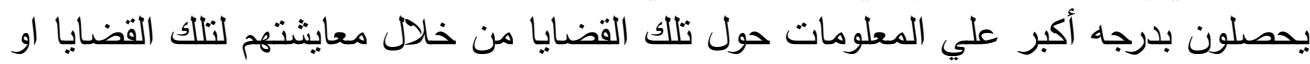

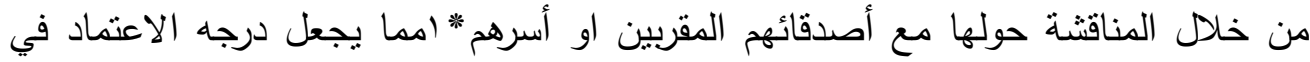

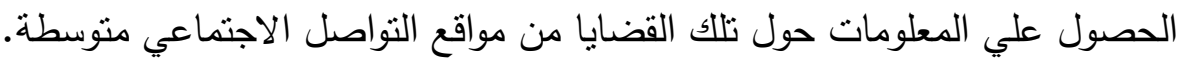

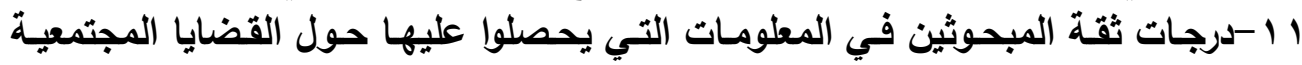

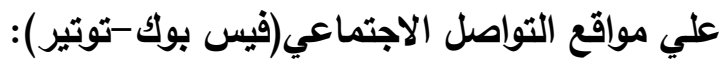
جدول (1)

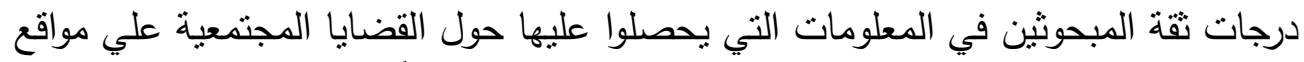

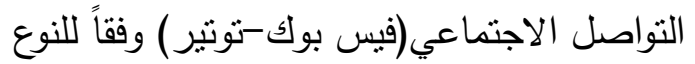

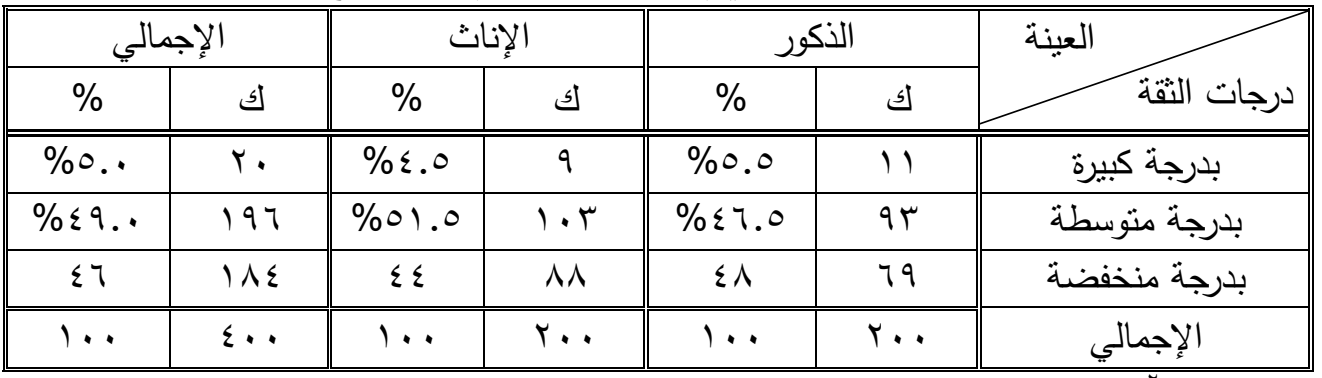

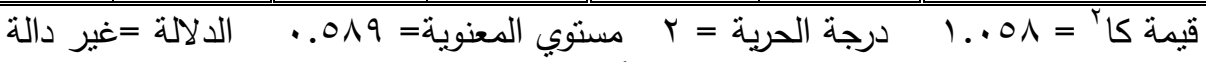

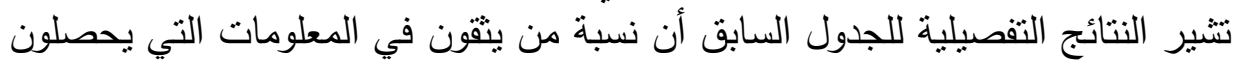

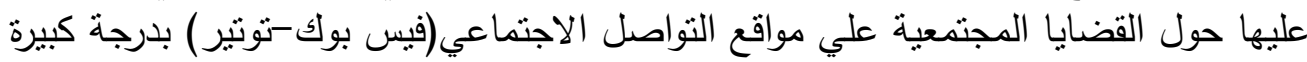

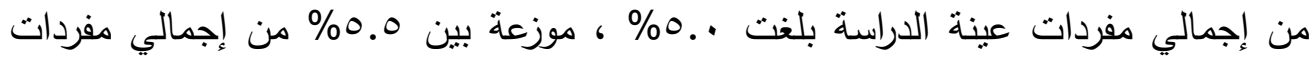

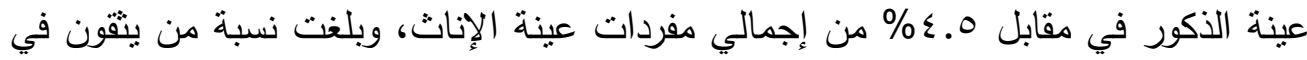

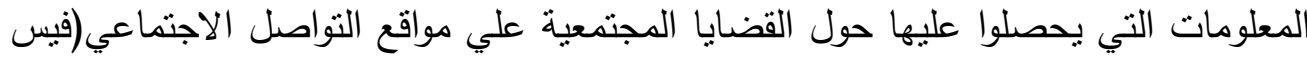

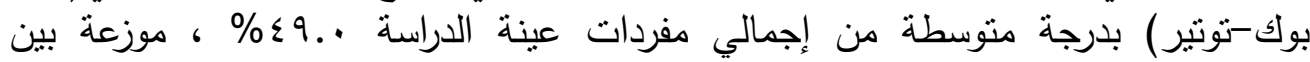

*جدول رقم( ) الفئات التي يتناقش معها المبحوثون حول القضايا المجتمعية علي مواقع التواصل

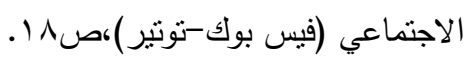




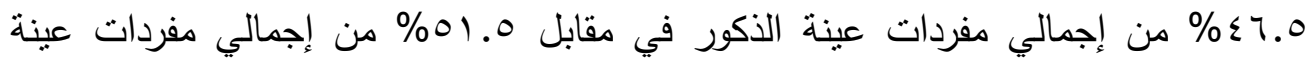

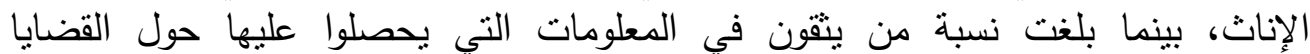

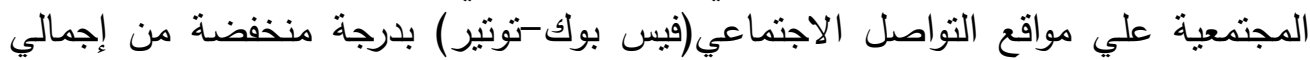

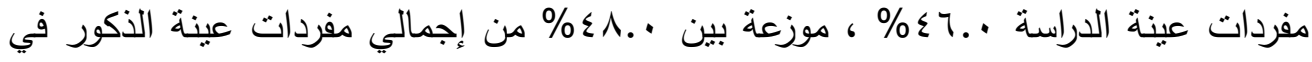

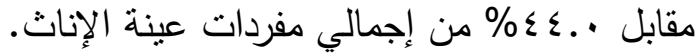

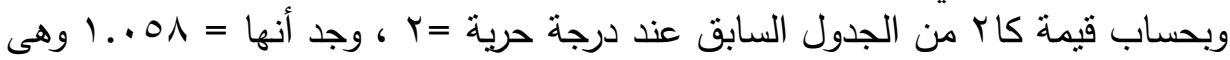

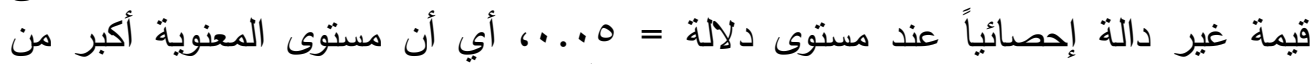

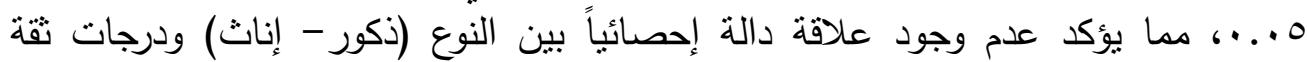

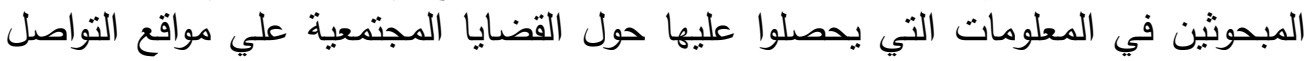

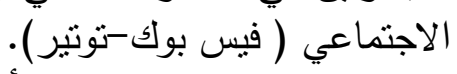

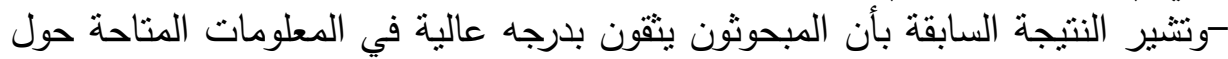

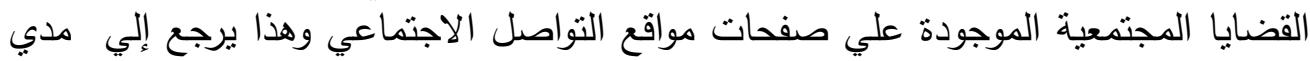

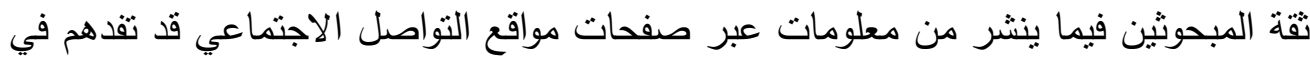

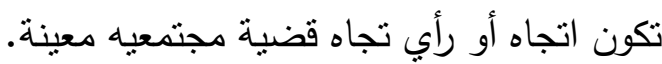

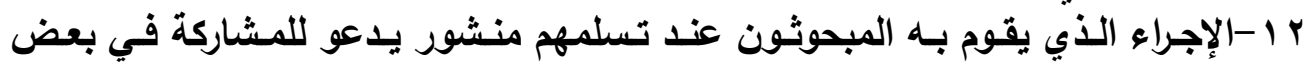

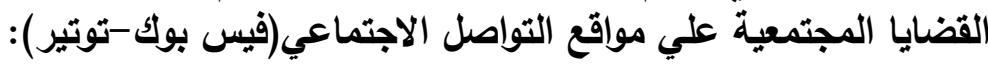
جدول (T)

الإجراء الذي يقوم به المبحوثون عند تسلمهم منشور يدعو للمشاركة في بعض القضايا

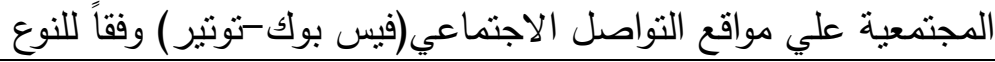

\begin{tabular}{|c|c|c|c|c|c|c|}
\hline \multicolumn{2}{|c|}{ الإجمالي } & \multicolumn{2}{|c|}{ الإناث } & \multicolumn{2}{|c|}{ الذكور } & العينة \\
\hline$\%$ & 5 & $\%$ & ك & $\%$ & ك5 & الإجراء - اء \\
\hline$\%$ \%.. & $r \leqslant 1$ & $\% 71.0$ & 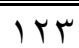 & $\% \circ 9$. & 111 & الاطلاع فقط \\
\hline \%Yr.A & 91 & \%rr.o & $\Sigma V$ & \%rr.. & $\varepsilon \varepsilon$ & المشاركة بفعالبة \\
\hline$\% 10.0$ & 74 & $\% \backslash \leqslant$. & rA & $\% \backslash \vee .$. & rร & عدم الاهتمام \\
\hline$\% 1.0$ & 7 & $\% 1 .$. & $r$ & $\%$ \%.. & $\varepsilon$ & حذف المنشور وحظره \\
\hline $1 \ldots$ & $\varepsilon \ldots$ & $1 \ldots$ & r.. & $1 \ldots$ & r.. & الإجمالى \\
\hline
\end{tabular}

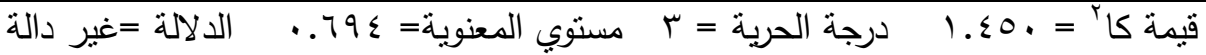

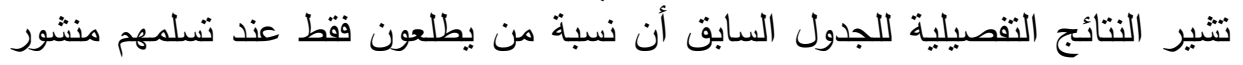

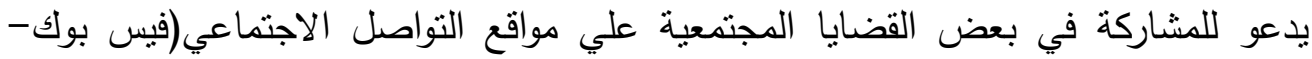

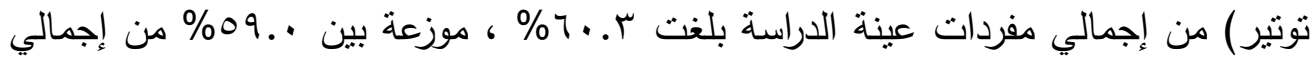
مفردات عينة الذكور في مقابل ه.

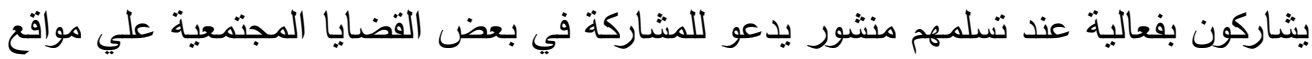

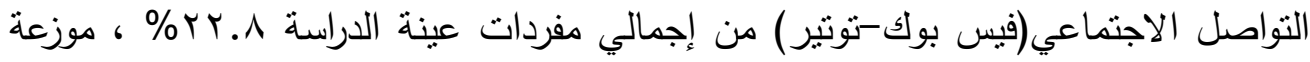

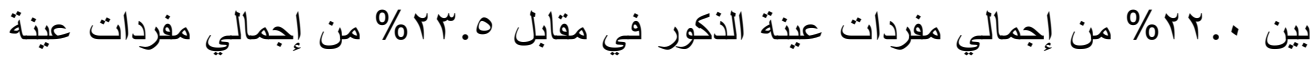

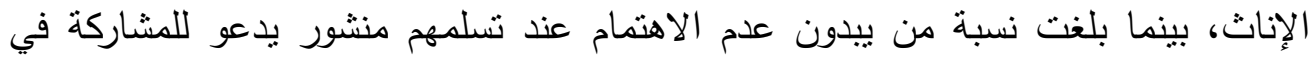


بعض القضايا المجتمعية علي مواقع التواصل الاجتماعي(فيس بوك-توتير) من إجمالي

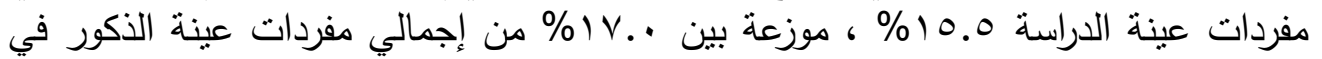

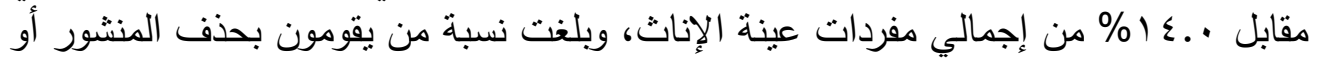

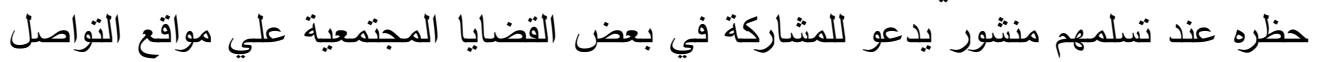

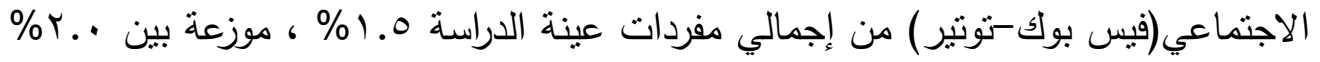

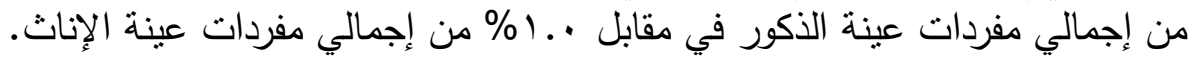

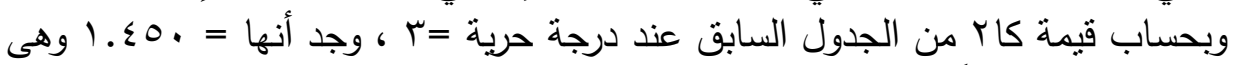

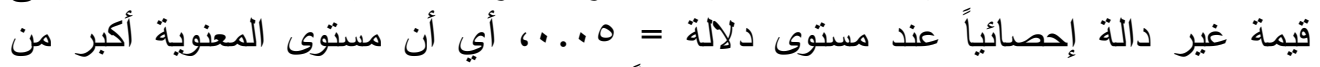

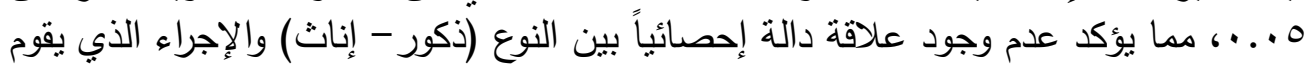

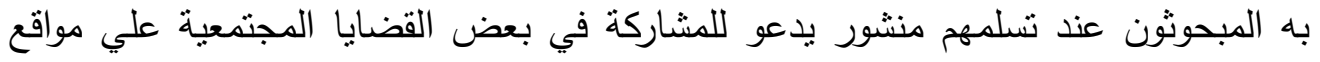

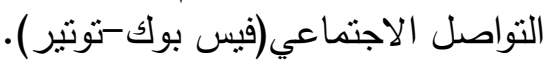
-وقد ترجع هذه النتيجة إلي مصداقية التئ المبحوثين في التعامل مع القضايا المجتمعية

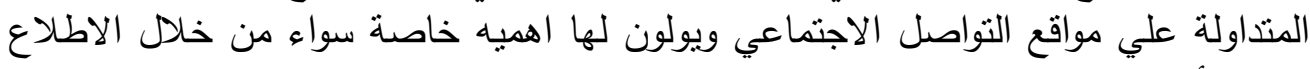

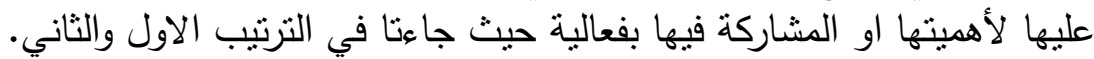

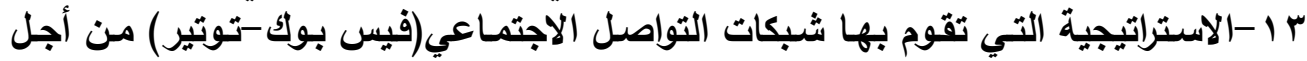
تحفيز الشباب الجامعي نحو المشاركة في القضايا المجتمعية من وجهية الاجئية نظر المبحوثين:

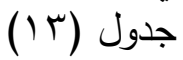

الاستراتيجية التي تقوم بها شبكات التواصل الاجتماعي(فيس بوكاتك-توتير ) من أجل تحفيز

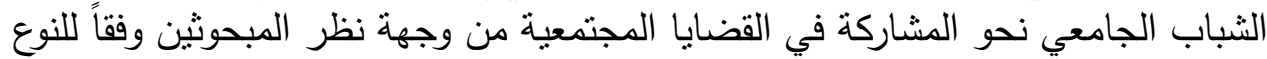

\begin{tabular}{|c|c|c|c|c|c|c|c|c|}
\hline \multirow{2}{*}{ الدلالة } & \multirow{2}{*}{ حقبمة } & \multicolumn{2}{|c|}{ 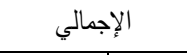 } & \multicolumn{2}{|c|}{ 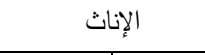 } & \multicolumn{2}{|c|}{ 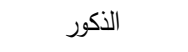 } & \multirow{2}{*}{ العبنة } \\
\hline & & $\%$ & 5] & $\%$ & 5 & $\%$ & 5) & \\
\hline غير دالة & $1 . \leqslant 0 \leqslant$ & \%or.. & rIr & $\% 01.0$ & $1 . r$ & $\% 0 \leqslant .0$ & 1.9 & تعمل علي زيادة الوعي الثقافي \\
\hline غبر دالة & $. r \mid r$ & $\% 01 . r$ & r.o & \%or.. & $1 \cdot \varepsilon$ & $\% 0 . .0$ & 1.1 & تتيح فرصة المشاركة في مناقثة \\
\hline غير دالة & I.NT & $\% \leqslant \Lambda . \wedge$ & 190 & $\% \leqslant \wedge$. & 97 & $\% \leqslant 9.0$ & 99 & تعتبر نافذه لحرية التعبير بطلاقه عن \\
\hline غير دالة &. ro. & $\% \leqslant \vee$. & 111 & $\% \leqslant 1.0$ & १V & $\% \leqslant 0.0$ & 91 & تعمل علي تقريب وجهات النظر \\
\hline غبر دالة & $1.1 \mathrm{KA}$ & $\% 19.0$ & VA & $\%$ r... & $\varepsilon$. & $\% 19$. & rᄉ & تعمل علي فتح فنوات نواصل مباشرة \\
\hline غير دالة & $. . \leqslant \Gamma \leqslant$ & $\% \backslash \vee . r$ & 79 & $\% \backslash \leq .0$ & $r q$ & $\% r \cdot .$. & $\varepsilon$. & تشكل مجموعات ضاغطة لحل \\
\hline$\cdots 0$ & $Y . \wedge \leq 0$ & $\% 1$ \%.० & $0 \leqslant$ & $\% 9.0$ & 19 & $\% \backslash \vee .0$ & ro & تعتبر قناة اتصالية لتشكيل رأيي \\
\hline & & $\varepsilon$. & & & & $r$. & & جملة من سئلوا \\
\hline
\end{tabular}


تنتير بيانات الجدول السابق إلى الاستراتيجية التي تقوم بها شبكات التواصل

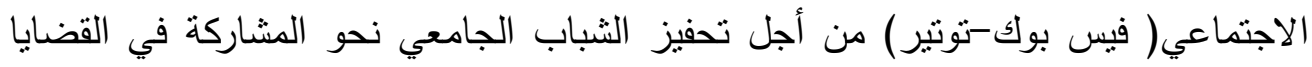
المجتمعية من وجهة نظر المبحوثين وفقاً للنوع ، حيث جاء في التريز الترنيب الأول تعمل علي زيادة الوعي التقافي بنسبة بلغت . .به\% من إجمالي مفردات عينة الدراسة، موزعة بين

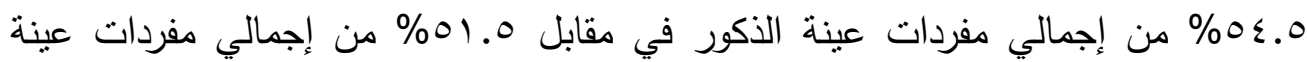

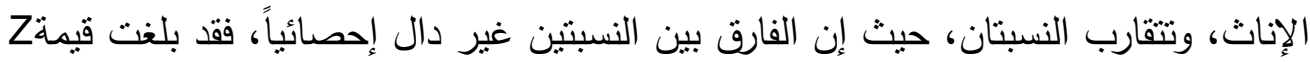
الدحسوبة ؟0ء.ا وهى أقل من القيمة الجدولية المنبئة بوجود علاقة فارقة بين النسبتين بمسنوى ثقة 90\%.

وجاء في الترتيب الثانيتتح فرصة المشاركة في مناقثة القضايا المجتمعية بنسبة بلغت r.

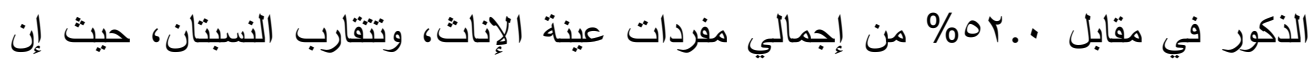

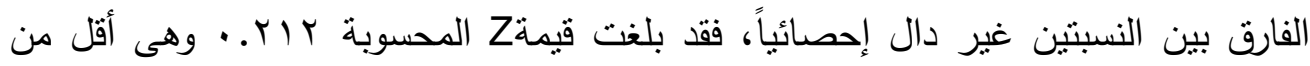

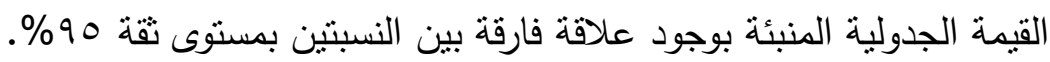
وجاء في الترتيب الثالث تعتبر نافذه لحرية التعبير بطلاقه عن القضايا المجتمعية

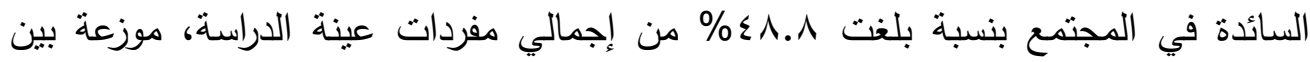

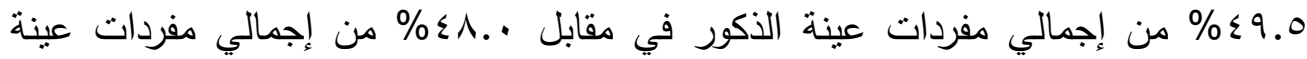

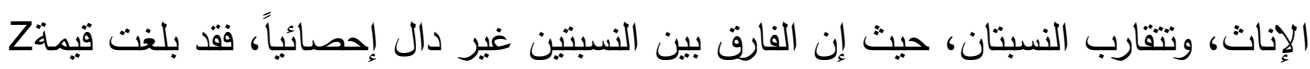

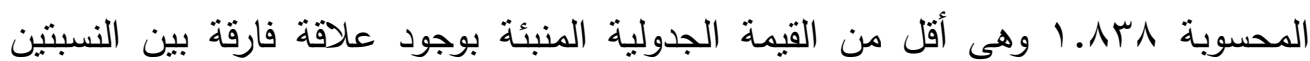
بمسنوى ثقة 90\%.

وجاء في الترتيب الرابع تعمل علي تقريب وجهات النظر حول القضايا المجتمعية بنسبة

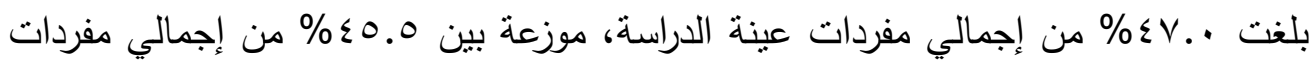

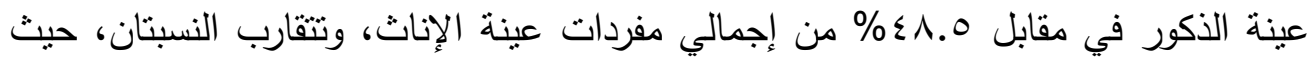

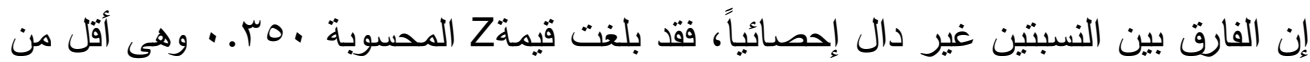

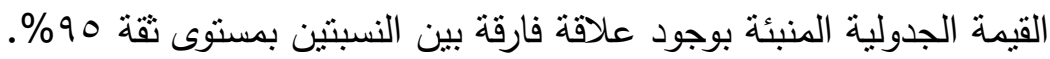
وجاء في الترتيب الخامس تعمل علي فتح قنوات تواصل مباشرة مع المسئولين وصناع

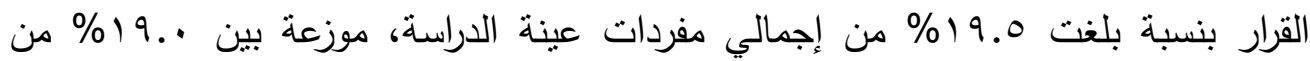

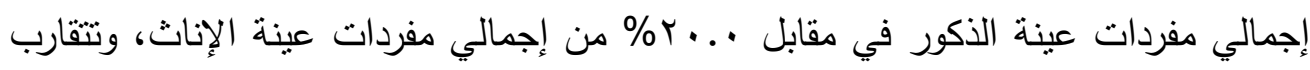


النسبتان، حيث إن الفارق بين النسبتين غير دال إحصائياً، فقد بلغت قيمةZ المحسوبة 1 1 ا ا وهى أقل من القيمة الجدولية المنبئة بوجود علاقة فارقة بين النسبتنين بمستوى ثقة 90\%. وجاء في الترتيب السادس تشكل مجموعات ضاغطة لحل بعض القضايا المجتمعية

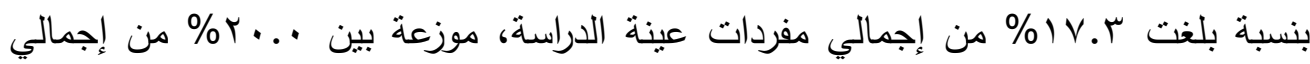

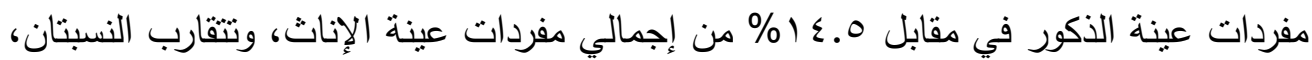

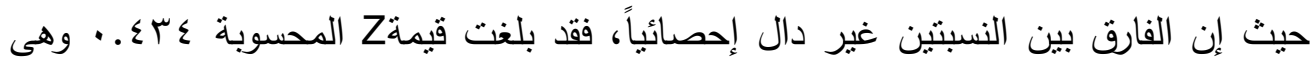

أقل من القيمة الجدولية المنبئة بوجود علاقة فارقة بين النسبتين بمستوى ثقة 90\%.

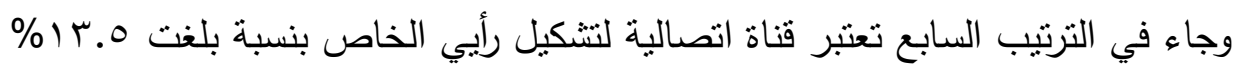

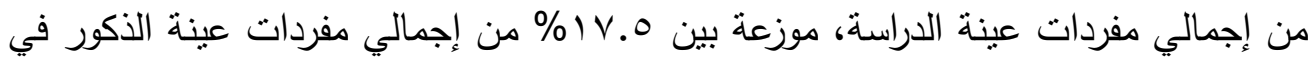
مقابل 9.9\% من إجمالي مفردات عينة الإناث، حيث يوجد فارق بين النسبتين دال إحصائياً

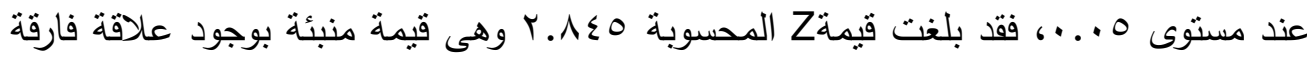

بين النسبتين بمستوى ثقة 90\%. -وتثبر النتيجة السابقة إلي دور مواقع التواصل الاجتماعي الفعال في فتح نوافذ متعددة لجذب الثباب الجامعي للمشاركة في القضايا المجتمعية. ؛ ا-أهم القضايا المجتمعية التي يهتم بمتابعتها المبحوثون ويبدون الرأي فيها من خلال شبكات التواصل الاجتماعي( فيس بوكث-توتير):

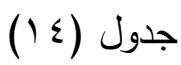

أهم القضايا المجتمعية التي يهتم بمتابعتها المبحوثون ويبدون الرأي فيها من خلال شبكات التواصل الاجتماعي(فيس بوك-توتير) وفقاً للنوع

\begin{tabular}{|c|c|c|c|c|c|c|c|c|}
\hline \multirow{2}{*}{ الدلالة ل } & \multirow{2}{*}{ قيمة z } & \multicolumn{2}{|c|}{ الإجمالي } & \multicolumn{2}{|c|}{ الإناث } & \multicolumn{2}{|c|}{ الذكور } & \multirow[t]{2}{*}{ العينة } \\
\hline & & $\%$ & ك5 & $\%$ & ك & $\%$ & ك5 & \\
\hline غير دالة & $1 . V Y \varepsilon$ & \%Ar.. & rTA & $\% \vee \wedge .0$ & $10 \mathrm{~V}$ & $\% \wedge 0.0$ & |VI & القضايا الاجتماعية \\
\hline غير دالة & .. $\leqslant 1$. & \%тा.r & $r \leqslant 0$ & \%чะ.. & IYA & $\% \circ \wedge .0$ & $11 \mathrm{~V}$ & القضايا السياسية \\
\hline غير دالة & .0 .9 & $\% \leq \Lambda . r$ & 194 & $\% \leqslant \vee .0$ & 90 & $\%$ \% १.. & 91 & القضايا الاقتصادية \\
\hline غير دالة & $\because r \mid \Lambda$ & $\% r . .0$ & Irr & $\%$ \% ..० & 09 & $\%+1.0$ & זי & القضايا الثقافية \\
\hline غير دالة & $\cdots \leqslant \leqslant 0$ & $\%$ \%४.А & 110 & $\%$ \% & $\leqslant 9$ & \%rr.. & 74 & القضايا الدينية \\
\hline$\ldots 0$ & r...o & $\%$ Ir.A & 01 & $\% \wedge .$. & 17 & $\%$ \% V.० & ro & القضايا الرياضية \\
\hline & & $\varepsilon$. & & r & & & & جملة من سئلوا \\
\hline
\end{tabular}


تشير بيانات الجدول السابق إلى أهم القضايا المجتمعية التي يهتم بمتابعتها المبحوثون

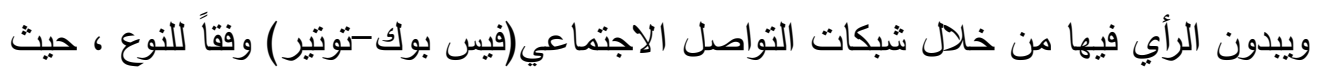

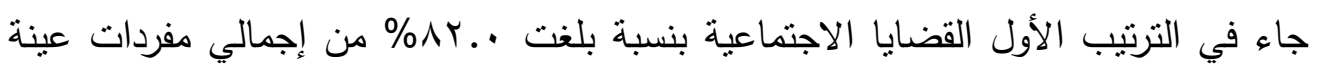

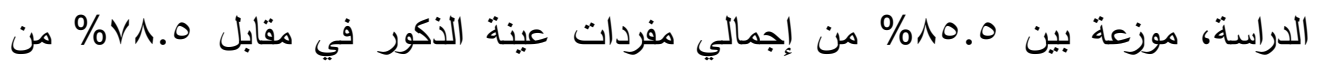
إجمالي مفردات عينة الإناث، وتتقارب النسبتان، حيث إن الفارق بين النسبتين غير دال

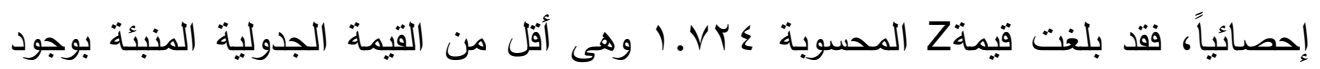

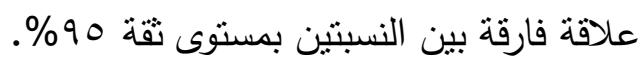

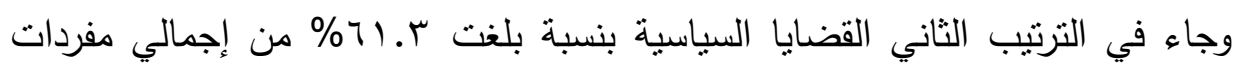

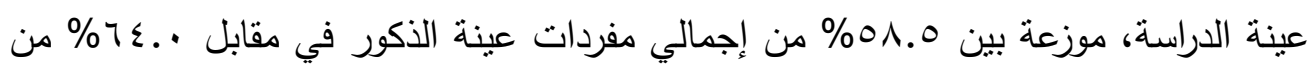
إجمالي مفردات عينة الإناث، وتتقارب النسبتان، حيث إن الفارق بين النسبتين غير دات دال

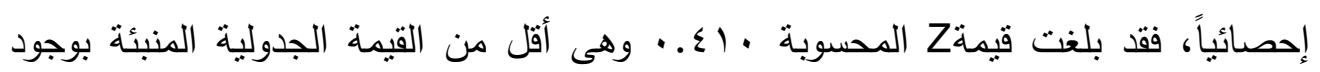
علاقة فارقة بين النسبتين بمستوى ثقة 90\% بهن

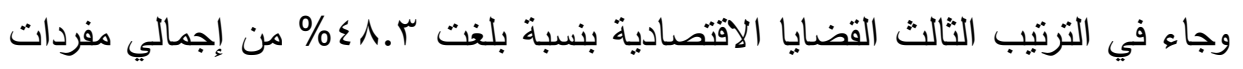

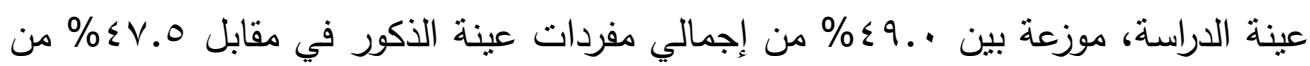
إجمالي مفردات عينة الإناث، وتثقارب النسبتان، حيث إن الفارق بين النسبتين غير دئه دال إحصائياً، فقد بلغت قيمةZ المحسوبة 9.9 . . وهى أقل من القيمة الجدولية المنبئة بوجود علاقة فارقة بين النسبتنين بمستوى ثقة 90\%

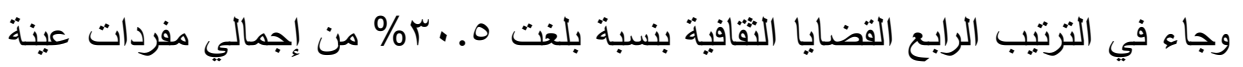

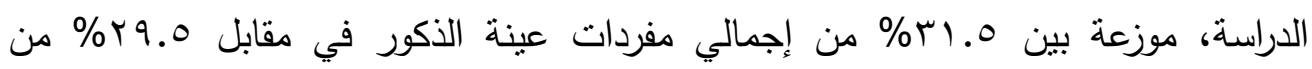

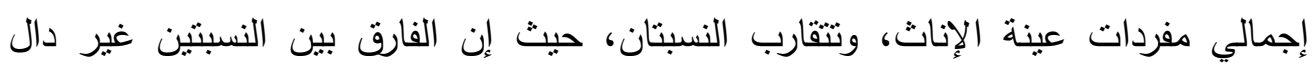

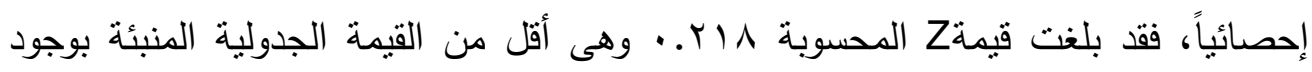
علاقة فارقة بين النسبتنين بمستوى ثقة 90\%

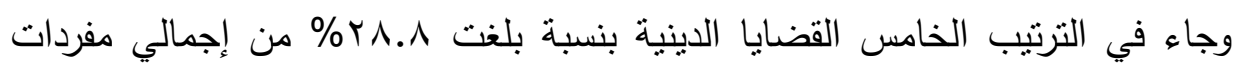

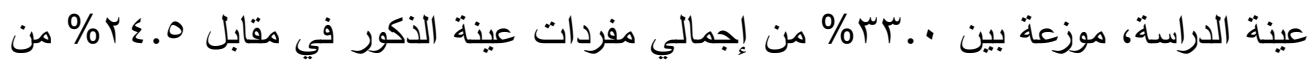
إجمالي مفردات عينة الإناث، وتتقارب النسبتان، حيث إن الفارق بين النسبتين غير دال

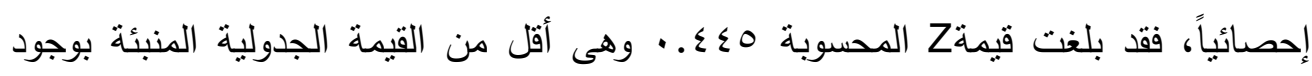
علاقة فارقة بين النسبتين بمستوى ثقة 90\% بهـ 
وجاء في الترتيب السادس القضايا الرياضية بنسبة بلغت ^.ب ا \% من إجمالي مفردات

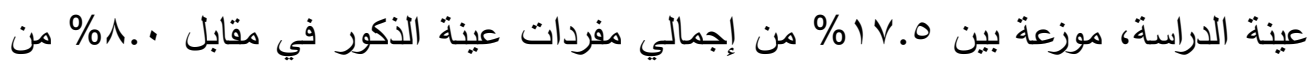

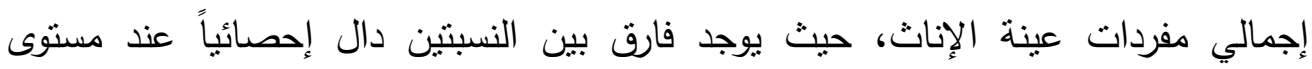

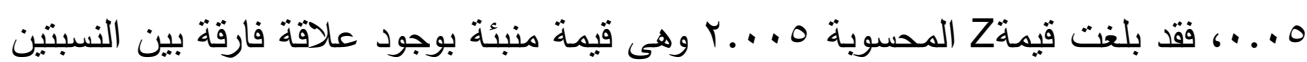

$$
\text { بمستوى ثقة 90\%. }
$$

كوتثير النتيجة السابقة إلي أن المبحوثين يتابعون الموضوعات السابقة بنفس الترتيب

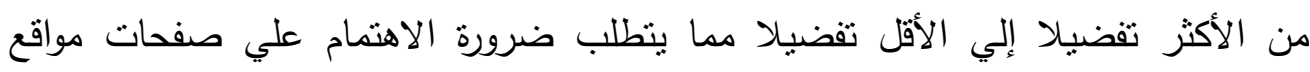

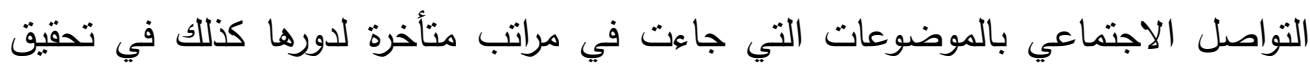
التمية المستدامة للمجتمع. ه 1 -استجابات المبحوثين علي مقياس التأثيرات الناتجة عن التعرض للقضايا المجتمعية

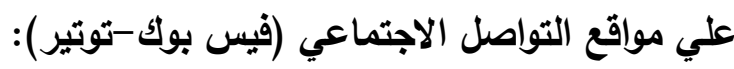
جدول (10)

استجاباتالمبحوثين علي مقياس التأثيرات الناتجة عن التعرض للقضايا المجتمعية علي مواقع التواصل الاجتماعي (فيس بوك-توتير )

\begin{tabular}{|c|c|c|c|c|c|c|}
\hline المتوسط & 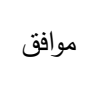 & محايد & 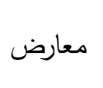 & \multicolumn{3}{|c|}{ الاستجابات } \\
\hline \multirow{2}{*}{ T. $\Sigma V$} & Y10 & 101 & rV & ك & \multirow{2}{*}{ تساعد في ترتيب اولوياتي تجاه القضايا التي أفضل } & \multirow{6}{*}{ 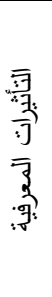 } \\
\hline & \%or.^ & $\%$ \%..० & $\% 7 . \wedge$ & $\%$ & & \\
\hline \multirow{2}{*}{ T.T人 } & $\mid 11$ & 119 & $r$. & ك5 & \multirow{2}{*}{ تشكيل اتجاهي تجاه بعض الموضوعات والقضايا } & \\
\hline & $\% \leqslant 0 . r$ & $\% \leqslant V . r$ & $\% \vee . ०$ & $\%$ & & \\
\hline \multirow{2}{*}{ מז.T } & $10 \leqslant$ & TrT & rT & ك & \multirow{2}{*}{ إزاله الغموض حول العديد من القضايا المجتمعية } & \\
\hline & \%ัヘ.० & $\% 00.1$ & $\% 0.1$ & $\%$ & & \\
\hline \multirow{2}{*}{ T.7T } & TVY & 119 & 9 & ك5 & \multirow{2}{*}{ تسبب لي شعور بالفتور واللامبالاة تجاه قضايا } & \multirow{4}{*}{ 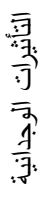 } \\
\hline & \%ч^. . & $\%$ \% ৭.А & \%r.r & $\%$ & & \\
\hline \multirow{2}{*}{ T.70 } & r79 & IrT & 9 & ك5 & \multirow{2}{*}{ تسبب لي بعض القلق والخوف من استمرار تللك القضايا المجتمعية } & \\
\hline & \%тV.r & $\% r \cdot .0$ & $\%$ \%.r & $\%$ & & \\
\hline \multirow{2}{*}{ T.OV } & rrq & 10. & 11 & ك5 & \multirow{2}{*}{ تخلق لدي رغبه بالحماس والمشاركة بفعالية في إيجاد } & \multirow{2}{*}{ 高: } \\
\hline & $\% 09 . \wedge$ & $\%$ \%r.o & $\%$ \%.A & $\%$ & & \\
\hline \multirow{2}{*}{ T.EY } & $r \leqslant r$ & $\wedge$ & $V T$ & ك5 & \multirow{2}{*}{ تخلق لاي رغبه في الخمول وتجنب القيام بأي تفاعل } & \multirow{2}{*}{ 弱: } \\
\hline & $\%$ \%.. & $\% r \cdot . r$ & $\% 19$. & $\%$ & & \\
\hline & \multicolumn{3}{|c|}{$\varepsilon \ldots$} & \multicolumn{3}{|c|}{ جملة من سئلوا } \\
\hline
\end{tabular}


تنشير بيانات الجدول السابق إلى استجابات المبحوثين علي مقياس التأثيرات الناتجة عن

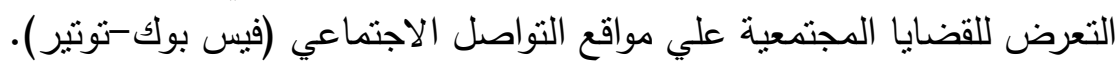

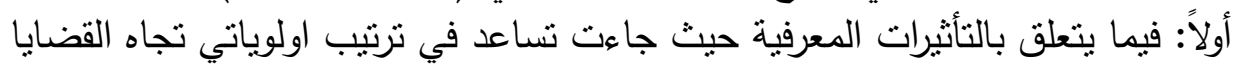

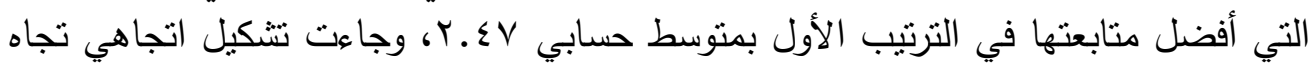

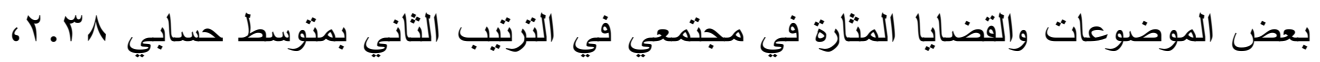

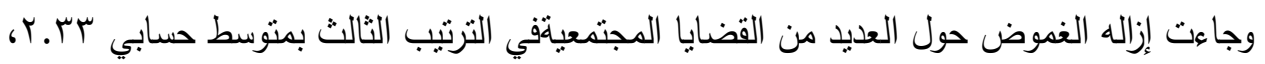

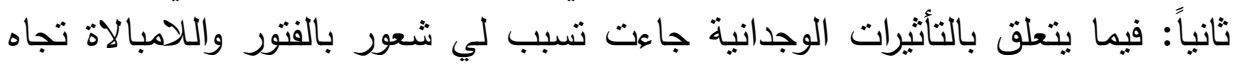

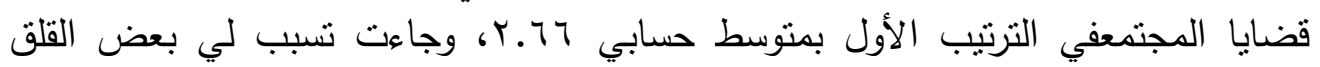

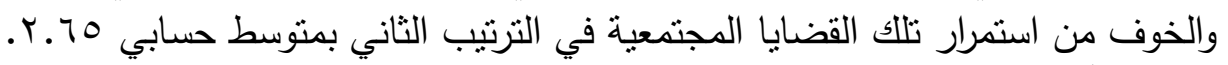

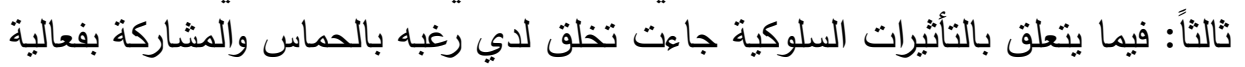

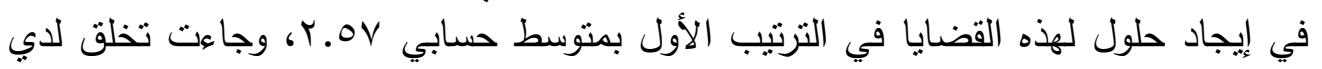

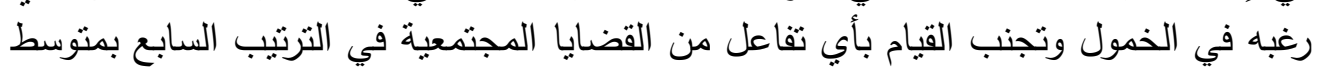

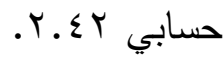
19 التواصل الاجتماعي (فيس بوكث-توتير):

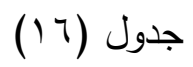

استجابات المبحوثين علي مقياس المشاركة في القضايا المجتمعية علي مواقع التواصل

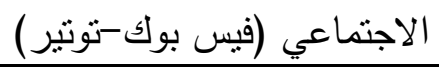

\begin{tabular}{|c|c|c|c|c|c|}
\hline المتوسط & 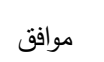 & 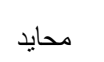 & \multicolumn{2}{|c|}{ 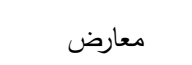 } & الاستجابة \\
\hline \multirow{2}{*}{ T.TV } & ז人 & $1 \cdot 1$ & 17 & ك & \multirow{2}{*}{ أثعر بالارتباح عندما أشارك زملائي في عمل ناجح } \\
\hline & $\% \vee \cdot . \wedge$ & \% ro.r & $\% \varepsilon$. & $\%$ & \\
\hline \multirow{2}{*}{ Y.77 } & TVY & 119 & 9 & ك & \multirow{2}{*}{ من الضروري معاقبه العامل المقصر في عمله } \\
\hline & $\%$ \%ฯ.. & $\%$ \%.^ & \%r.r & $\%$ & \\
\hline \multirow{2}{*}{ T.7T } & rNT & $1 \cdot 1$ & iv & ك & \multirow{2}{*}{ تتمية المجتمع مسئولية كل مواطن فيه } \\
\hline & $\% \vee \cdot .0$ & $\%$ \% & $\% \varepsilon . r$ & $\%$ & \\
\hline \multirow{2}{*}{ Y.70 } & r79 & IrT & 9 & ك & \multirow{2}{*}{ نجاح أي جماعه في أي عمل تقوم به بيطلب التعاون بين } \\
\hline & \%TV.r & $\%+\cdot .0$ & \% r.r & $\%$ & \\
\hline \multirow{2}{*}{ T.OV } & r ז & 104 & 1. & ك & \multirow{2}{*}{ عندما أكلف بعمل أبذل فيه قصار جهدي } \\
\hline & $\% 09.0$ & \%ґл.. & $\%$ Y.o & $\%$ & \\
\hline \multirow[b]{2}{*}{ r.OV } & rrq & 10. & 11 & ك & \multirow[b]{2}{*}{ من واجبات كل مواطن أن يفه خطط التنمية المجتمعية في بلده } \\
\hline & $\% 09 . \wedge$ & $\%$ \% . & $\%$ r.^ & $\%$ & \\
\hline \multirow{2}{*}{ r.or } & rrt & $17 \varepsilon$ & $1 \leq$ & 5 & \multirow{2}{*}{ احب ان اعمل ما تتفق عليه جماعه انا عضو بها } \\
\hline & $\% 00.0$ & $\% \leqslant 1 .$. & $\%$ \%.० & $\%$ & \\
\hline \multirow{2}{*}{ r. $\leqslant 9$} & YIA & 17. & rt & 5 & \multirow{2}{*}{ إذا لم توجد رقابة شديدة ومستمرة علي كل فرد فإنه سوف } \\
\hline & $\% 0 \leqslant .0$ & $\% \varepsilon \ldots$ & $\% 0.0$ & $\%$ & \\
\hline T. $\leqslant V$ & rio & 101 & rV & ك) & من واجب كل مواطن أن يقدم مقترحاته لحل قضايا \\
\hline
\end{tabular}




\begin{tabular}{|c|c|c|c|c|c|}
\hline & $\%$ \%r.^ & $\%$ \% ४.० & $\%$ \%.^ & $\%$ & \\
\hline \multirow{2}{*}{ T.TA } & $|\wedge|$ & 119 & $r$. & 5 & \multirow{2}{*}{ كل فرد بستطيع ان يشارك في حل قضايا مجتمعه } \\
\hline & $\% \leqslant 0 . r$ & $\% \leqslant \vee . r$ & $\%$ \%.० & $\%$ & \\
\hline \multirow{2}{*}{ T.rT } & $10 \leqslant$ & YYT & $r T$ & ك5 & \multirow{2}{*}{ أحب أن أوضح لزملائي بعض القضايا المجتمعية في } \\
\hline & $\%$ \%ґ.० & $\% 00 . \wedge$ & $\% 0.1$ & $\%$ & \\
\hline \multirow{2}{*}{ T.YO } & 104 & $19 \varepsilon$ & or & ك & \multirow{2}{*}{ 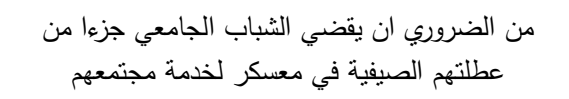 } \\
\hline & $\%$ \%४.r & $\% \leqslant \wedge .0$ & \%।T.r & $\%$ & \\
\hline \multirow{2}{*}{ T.rT } & ITr & TrA & $\varepsilon$. & ك5 & \multirow{2}{*}{ أثنارك زملائي في الحديث عن التتمية المجتمعية } \\
\hline & \%rr.. & $\% \circ v_{\text {.. }}$ & $\% 1 \ldots$ & $\%$ & \\
\hline \multirow{2}{*}{ T.10 } & 111 & $T Y \xi$ & 01 & ك & \multirow{2}{*}{ ليس من الضروري أن يتازل الثخص عنده عن بعض حقوق امرهم } \\
\hline & $\%$ \%४.० & $\% 04$. & $\% \backslash \leq .0$ & $\%$ & \\
\hline \multirow[b]{2}{*}{ T. I } & ITV & $r \cdot r$ & VI & ك & \multirow{2}{*}{ عندما أثنرك في عمل مع زملائي أحب أن يتحدث } \\
\hline & $\%$ \% & $\% 0 . .0$ & $\% \backslash \vee . \wedge$ & $\%$ & \\
\hline \multirow{2}{*}{ r.. $q$} & $1 Y 4$ & 110 & 19 & 5 & \multirow{2}{*}{ أفضل العمل منفرد عن العمل في جماعه } \\
\hline & $\%$ \% & $\% \leq 4 . r$ & \%Yr.r & $\%$ & \\
\hline \multirow{2}{*}{ r... } & 91 & rIA & 91 & ك & \multirow{2}{*}{ تغضبني معارضة زملائي لأرائي عندما نكون مشتركين } \\
\hline & \%rr.A & $\% \circ \leq .0$ & \%rr.A & $\%$ & \\
\hline \multirow{2}{*}{1.99} & 91 & 199 & $1 . r$ & ك & \multirow{2}{*}{ لا أحب ان أتحدث عن القضايا المجتمعية في بلدي } \\
\hline & $\%$ \% & $\%$ \%१.^ & $\%$ \%०.ᄉ & $\%$ & \\
\hline \multirow[b]{2}{*}{$1.9 \mathrm{~V}$} & $\wedge 1$ & rro & $9 \leq$ & 5 & \multirow{2}{*}{ 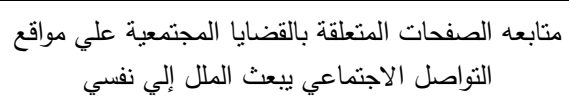 } \\
\hline & $\%$ \%r.r & $\% \circ 4 . r$ & $\%$ \%r.० & $\%$ & \\
\hline \multirow[b]{2}{*}{1.19} & $1 \cdot v$ & $1 \leqslant r$ & 10 & ك & \multirow{2}{*}{ 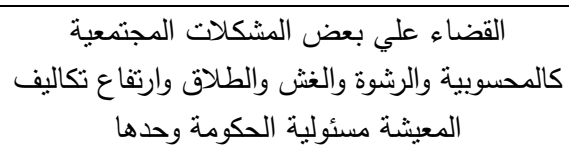 } \\
\hline & $\%$ \%ч.А & $\%$ \%०.А & $\%$ \%r.o & $\%$ & \\
\hline \multirow{2}{*}{$1 . \wedge \mathrm{V}$} & 99 & $1 \leqslant 9$ & 104 & ك5 & \multirow{2}{*}{ الاشتراك في عمل مجتمعي مع جماعه امر يضايقني } \\
\hline & $\%$ \%.A & \%rv.r & $\%$ \%४.. & $\%$ & \\
\hline \multirow{2}{*}{ l.Ar } & 94 & $1 \leqslant 1$ & 177 & ك & \multirow{2}{*}{ الكساهمة في حل الششاكل التي تتثأ في المجتمع من } \\
\hline & \%rr.r & $\%$ ro.r & $\% \leqslant 1.0$ & $\%$ & \\
\hline \multirow{2}{*}{$1 . \vee \wedge$} & $V \varepsilon$ & $17 \varepsilon$ & 174 & 5 & \multirow{2}{*}{ بعض القضايا المجتمعية لا يمكن حلها لأن المحاولات } \\
\hline & $\% \backslash 1.0$ & $\%$ \%).. & $\% \leqslant \cdot .0$ & $\%$ & \\
\hline I vy & $v \cdot$ & $17 \mathrm{~V}$ & $17 r$ & ك5 & Lh the \\
\hline & $\% \backslash \vee .0$ & $\%$ \%).^ & $\% \varepsilon \cdot . \wedge$ & $\%$ & 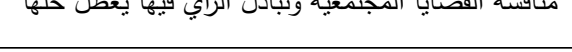 \\
\hline L $v^{\prime}$ & $V \varepsilon$ & $1 \leqslant r$ & $11 \varepsilon$ & ك5 & ليس من الضروري متابعه القضايا والتغييرات التي تجري \\
\hline $1 . n$ & $\% \backslash \wedge .0$ & $\%$ \% & $\% \leq 7$. & $\%$ & 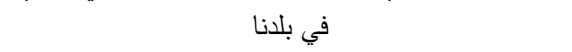 \\
\hline 179 & $\mathrm{vr}$ & irA & 199 & ك & \\
\hline 1.17 & $\% \backslash \wedge . \Gamma$ & \%rr.. & $\% \leq 9 . \wedge$ & $\%$ & 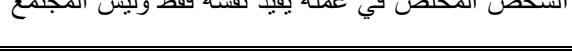 \\
\hline & & & & & جملة من سئلوا \\
\hline
\end{tabular}

تشير بيانات الجدول السابق إلى استجابات المبحوثين علي مقياس المشاركة في القضايا

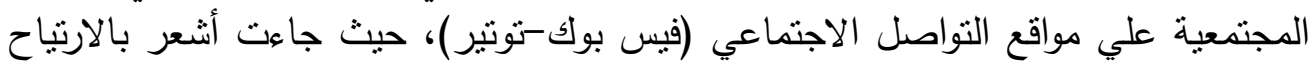

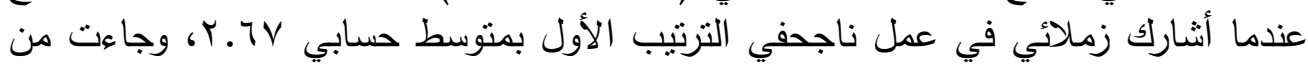




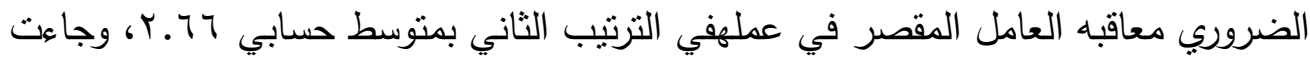

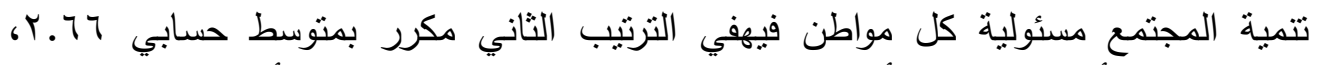

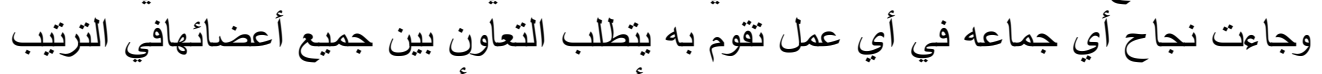

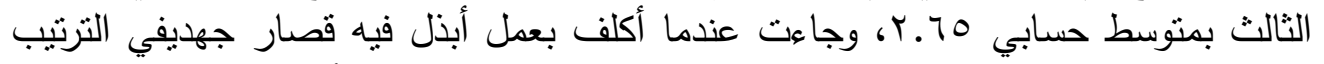

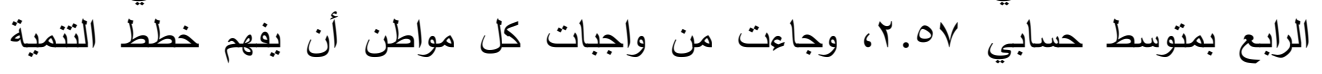

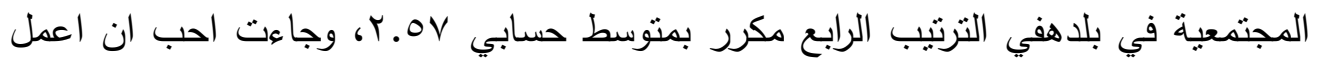

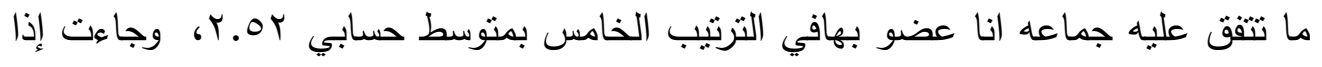

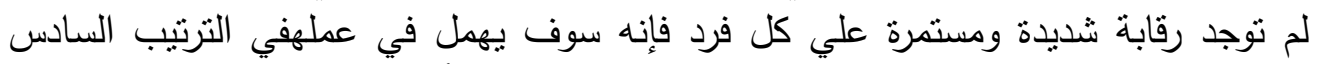

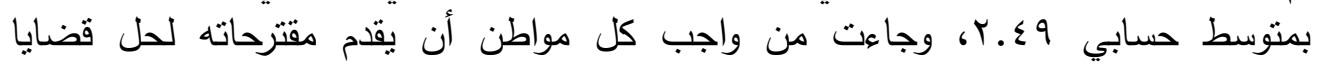

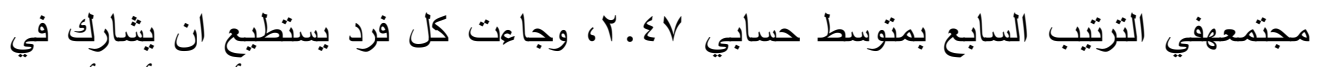

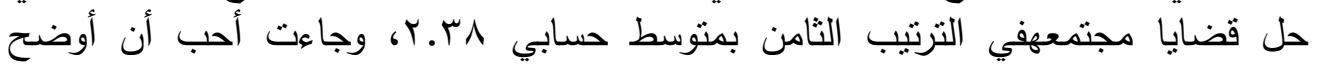

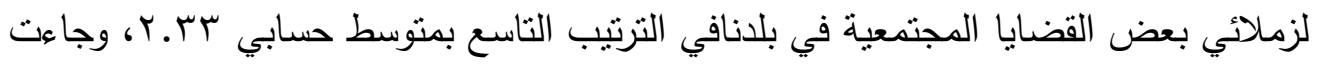

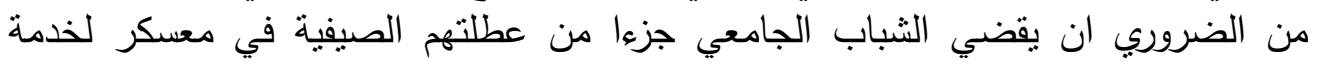

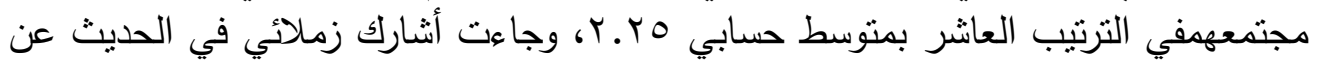

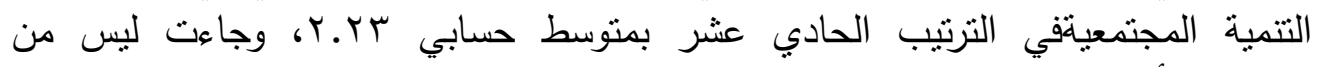

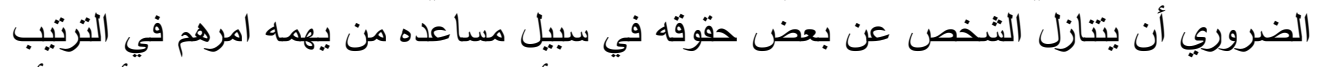

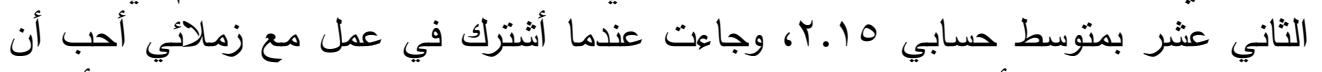

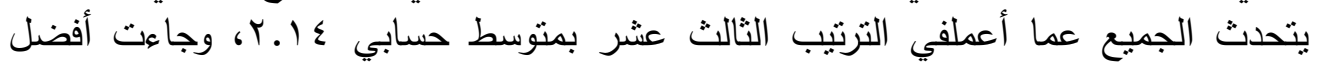

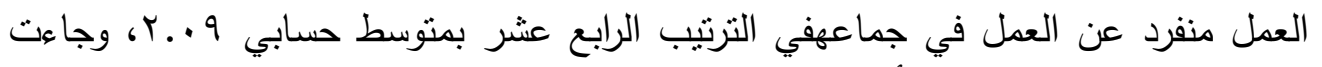

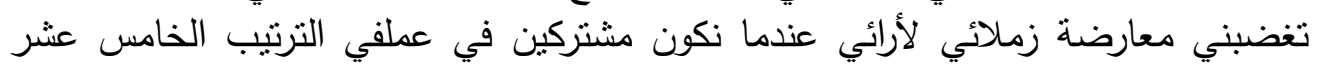

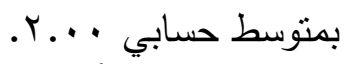

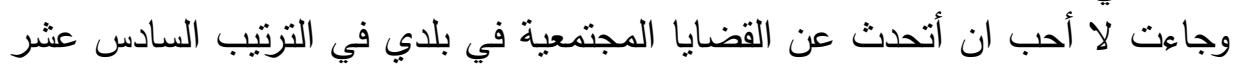

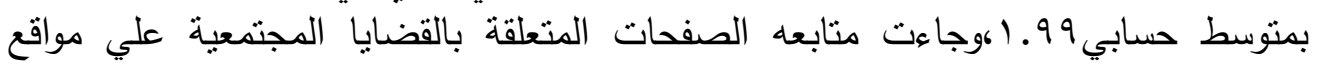

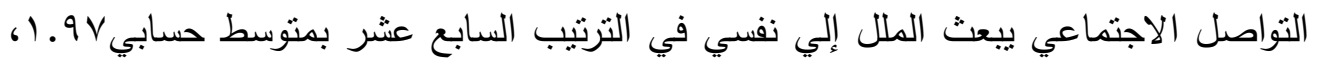

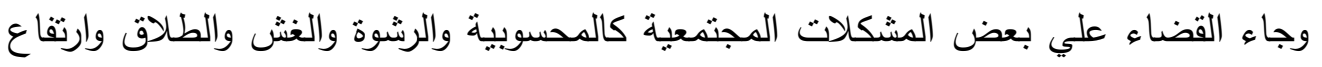

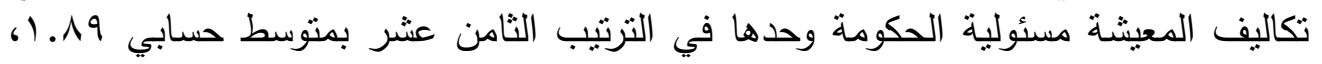

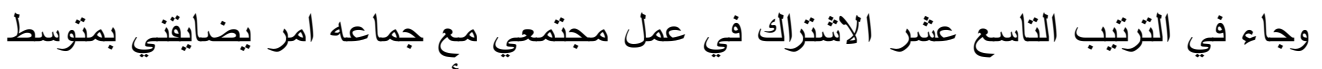

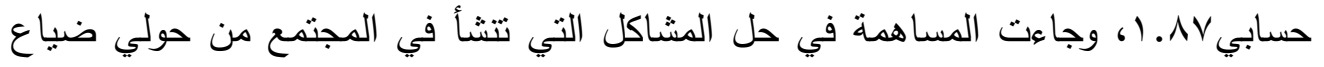

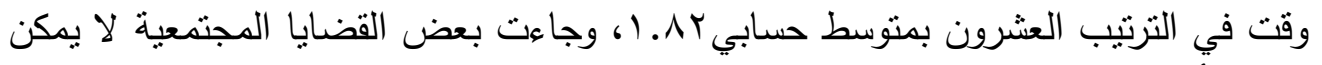

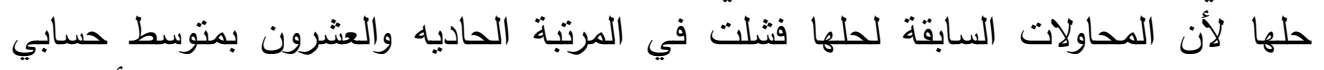

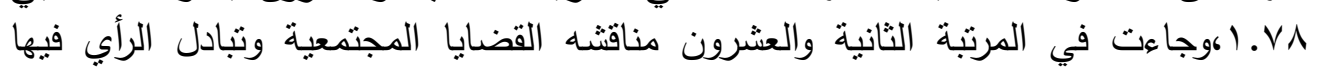

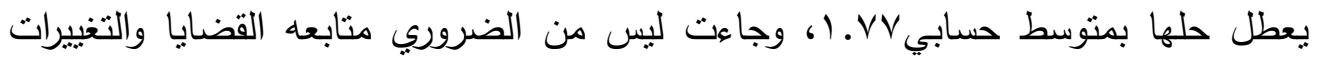

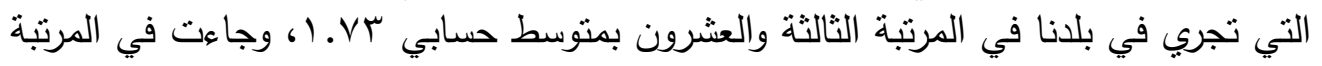
الرابعة والعشرون والاخيرة الثخص المخلص في عمله يفيد نفسه فقط وليس المجتمع بمنوسط 


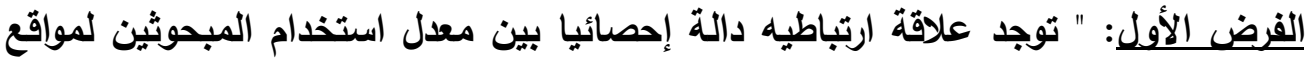

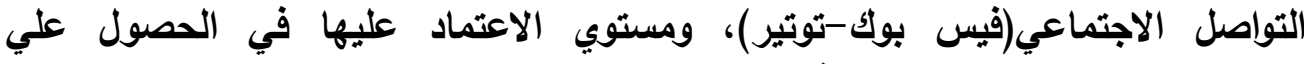

$$
\text { جدول (IV) }
$$

المعلومات حول القضايا المجتمعية"

معامل ارتباط بيرسون لقياس العلاقة بين معدل استخدام المبحوثين لمواقع التواصل

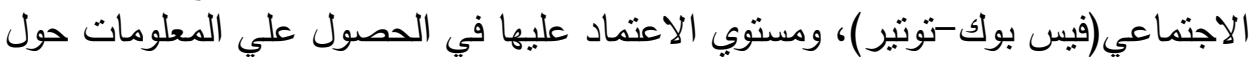

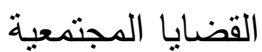

\begin{tabular}{|c|c|c|}
\hline \multicolumn{2}{|c|}{ مستوي الاعتماد عليها في الحصول علي المعلومات حول القضايا } & \multirow{2}{*}{ المتغيرات } \\
\hline الدلالة & معامل الارتباط & \\
\hline$\cdots+1$ & .rrq & 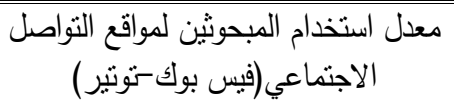 \\
\hline
\end{tabular}

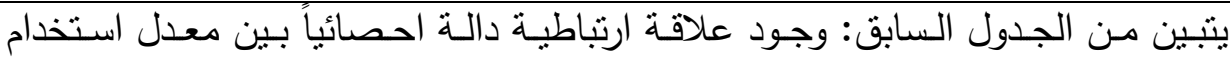

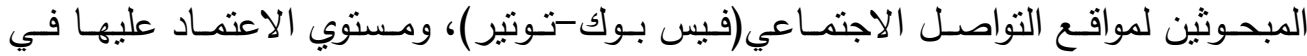

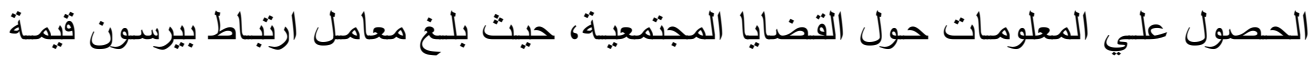

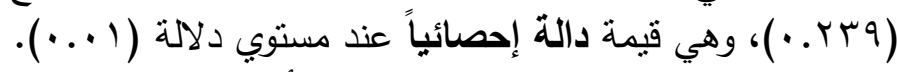
- مما سبق بتضحتحقق صحه الفرض الأول.

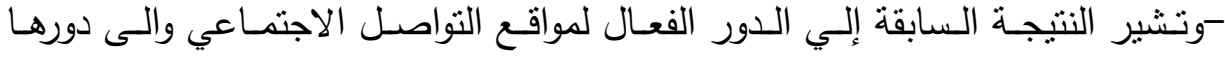

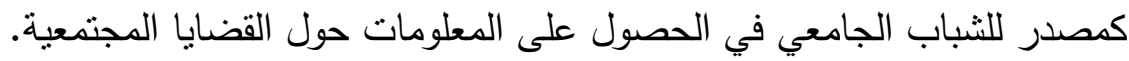

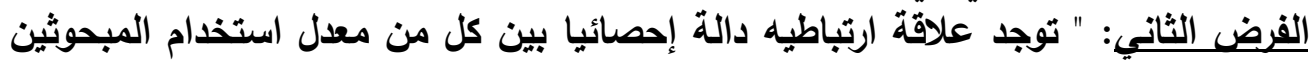

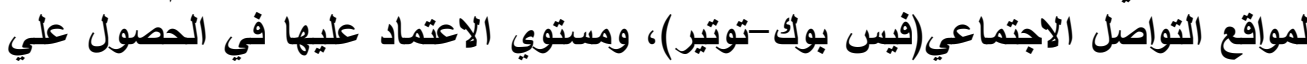

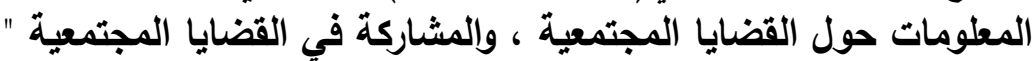

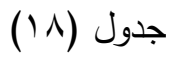

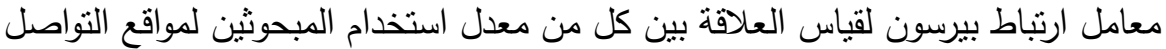

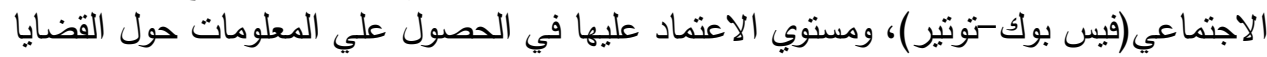

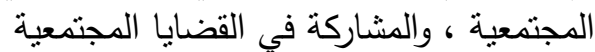

\begin{tabular}{|c|c|c|}
\hline \multicolumn{2}{|c|}{ المشاركة في القضايا المجتمعية } & \multirow{2}{*}{ المتغيرات } \\
\hline 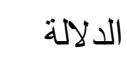 & معامل الارتباط & \\
\hline$\cdots+1$ & $\cdot . \leqslant 01$ & 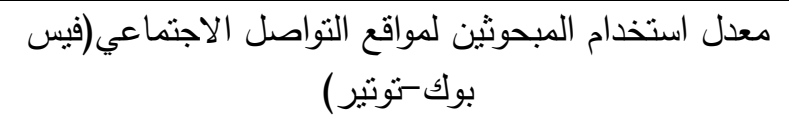 \\
\hline$\ldots .0$ & $.1 \vee \varepsilon$ & 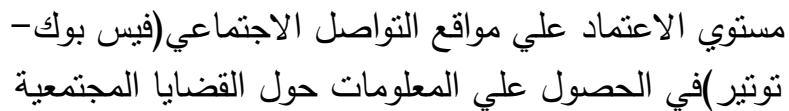 \\
\hline
\end{tabular}


يتبين من الجدول السابق:

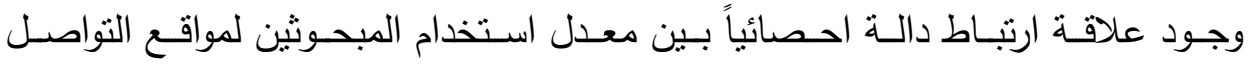

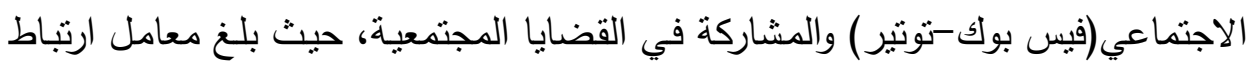

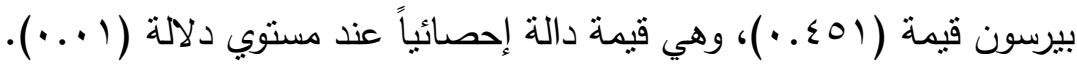

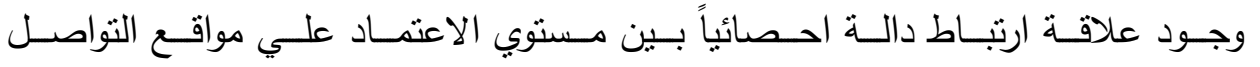

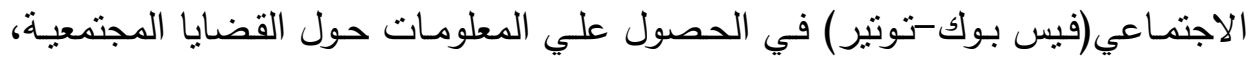

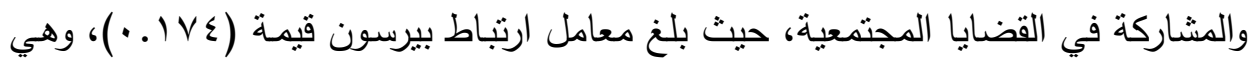

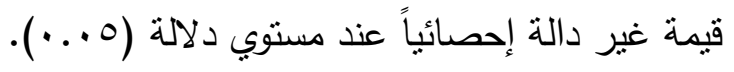

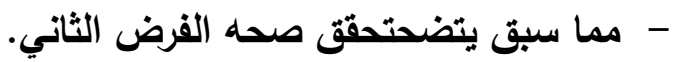

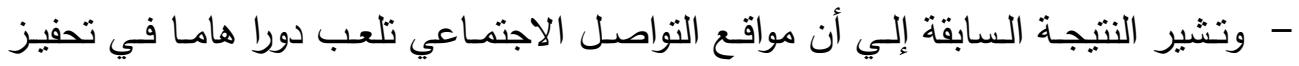
الثنباب علي المشاركة في القضايا المجتمعية. الفرض الثالث: " توجد فروق دالة إحصائيا بين متوسطات درجاتئ الثيات المبحوثين علي مقياس

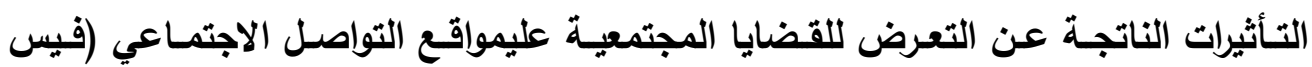
بوك-توتير) تبعاً للنوع".

$$
\text { جدول (19) }
$$

نتائج اختبار (ت) لدلالة الفروق بين متوسطات درجات المبحوثين علي مقياس التأثيرات الناتجة عن

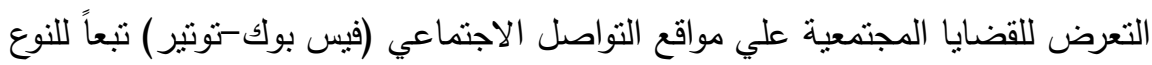

\begin{tabular}{|c|c|c|c|c|c|c|}
\hline الد الالة & قيمة (ت) & $\varepsilon$ & r & 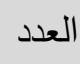 & العينة & أبعاد المقياس \\
\hline \multirow{2}{*}{ غير دالة } & \multirow{2}{*}{.10} & D & V.110. & r.. & الذكور & \multirow{2}{*}{ التأثيرات المعرفية } \\
\hline & & $1 . Y 9 \leq 74$ & $v .170$. & r.. & الإناث & \\
\hline \multirow{2}{*}{$\ldots 0$} & \multirow{2}{*}{$1.9 V$} & 91979. & O.KT.. & r.. & الذكور & \multirow{2}{*}{ التأثنيرات الوجدانية } \\
\hline & & $1009 \varepsilon$. & 0.490. & r.. & الإناث & \\
\hline \multirow{2}{*}{$\ldots}$. & \multirow{2}{*}{$r . \leq \varepsilon r$} & $1.1 \leq 71$. & 纟.^.०. & r.. & الذكور & \multirow{2}{*}{ التأثيرات السلوكية } \\
\hline & & $.978 \times 4$ & $0.1 V \ldots$ & r.. & الإناث & \\
\hline
\end{tabular}

تشير نتائج نطبيق اختبار "ت" إلي: عدم وجود فروق بين متوسطات درجات المبحوثين علي مقياس التأثيرات المعرفية الناتجة

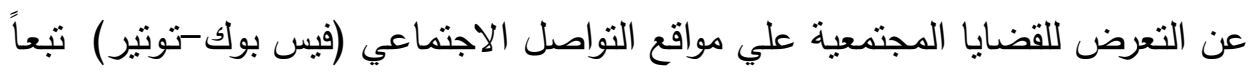
للنوع ، حيث بلغت قيمة "ت" ( (10 . ) وهي قيمة غير دالة إحصائباً عند مستوي دلالة (0. . ). 
وجود فروق بين متوسطات درجات المبحوثين علي مقياس التأثيرات الوجدانية الناتجة عن

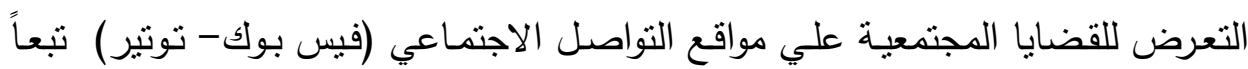

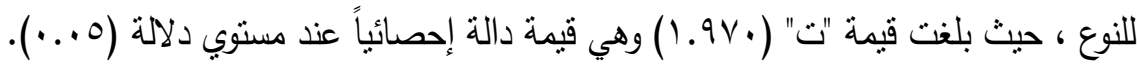

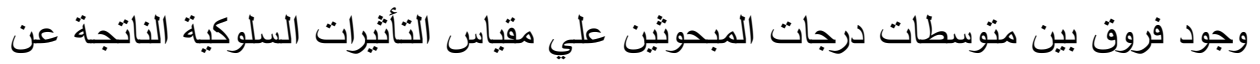

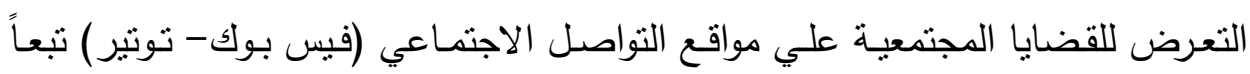

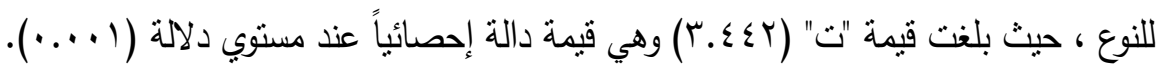
- مما سبق يتضح تحقى صحة الفرض الثالث جزئيا. - حيث لا توجد فروق بين متوسطات درجات المبحوثين علي مقياس التأثيرات المعرفية

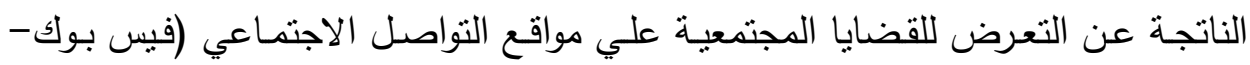
توتير) نتعاً للنوع. - توجد فروق بين متوسطات درجات المبحوثين علي مقياس التأثيرات الوجدانية والسلوكية

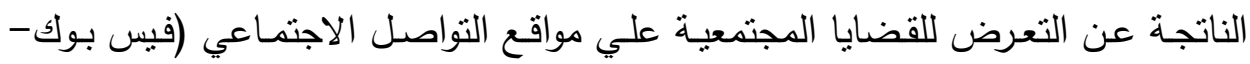
نوتير) تنعاً للنوع.

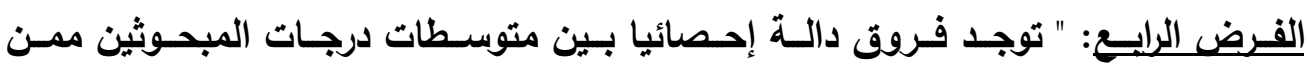

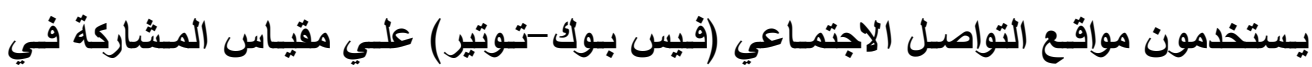
القضايا المجتمعية تبعاً للنوع.

$$
\text { جدول (r. }
$$

نتائج اختبار (ت) لدلالة الفروق بين متوسطات درجات المبحوثين ممن يستخدمون مواقع التواصل

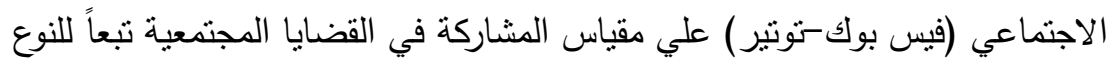

\begin{tabular}{|c|c|c|c|c|c|}
\hline الدلالة & قيمة (ت) & $\varepsilon$ & r & العدد & العينة \\
\hline \multirow{2}{*}{. .0} & \multirow{2}{*}{ r. roq } & $\Lambda . \Sigma \cdot \varepsilon \cdot Y$ & $0 \wedge .1 \vee 0$. & r.. & الذكور \\
\hline & & ס ז ד ר. & $07 . \leqslant 00$. & r.. & الإناث \\
\hline
\end{tabular}

تشبير نتائج تطبيق اختبار "ت": إلي وجود فروق دالة إحصائياً بين منوسطات درجات

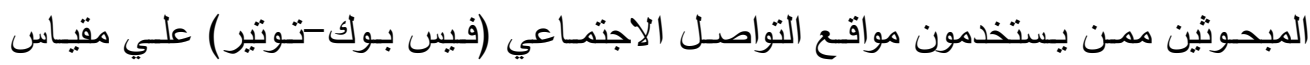

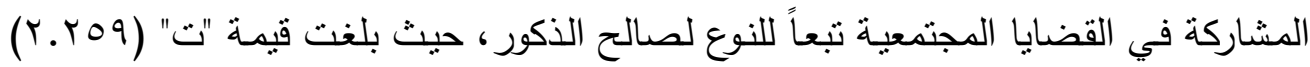
وهي قيمة دالة إحصائياً عند مستوي دلالة (0. . •). 
- مما سبق يتضح تحقق صحه الفرض الرابع. الفرض الغـامس: " توجد فـروق دالـة إحصائيا بـين متوسطات درجـات المبحوثين ممـن

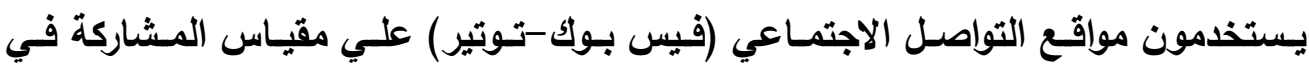
القضايا المجتمعية تبعاً لمستوي الاعتماد علي تلك المواقع في الحصول علي المعلومـات حول القضايا المجتمعية.

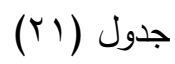

نتائج اختبار تحليل التباين الأحاديلدلالة الفروق بين منوسطات درجات المبحوثين ممن بستخدمون

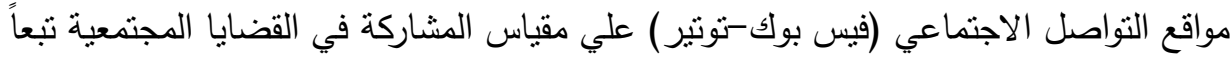

لمستوي الاعتماد علي تلك المواقع في الحصول علي المعلومات حول القضايا المجتمعية.

\begin{tabular}{|c|c|c|c|c|c|}
\hline الدلالة & قيمة ف & المربعات & الحرية & مجموعات & مصدر التباين \\
\hline \multirow{3}{*}{$\ldots 1$} & \multirow{3}{*}{ r.9Yo } & $|V \Lambda| V \mid$. & r & roT.r $\leqslant r$ & بين المجموعات \\
\hline & & $\leqslant 0.490$ & एवV & $10 \mathrm{~V} 9.7 \mathrm{rV}$ & داخل المجموعات \\
\hline & & & r१q & $1940.9 \vee 9$ & المجموع \\
\hline
\end{tabular}

تشبير نتائج نطبيق اختبار " تحلبل التباين الأحادي": إلي وجود فروق بين متوسطات

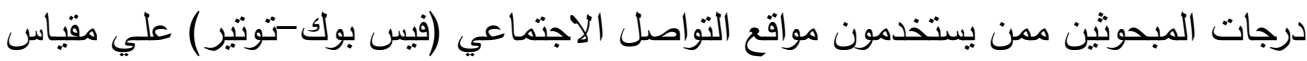

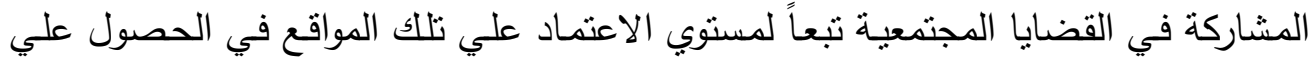

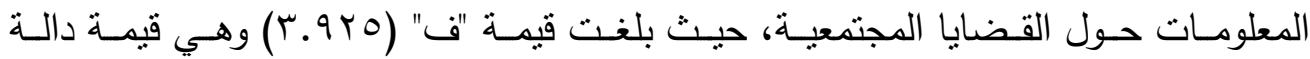

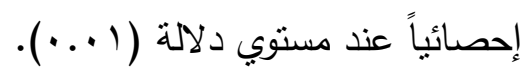
ولمعرفـة مصدر ودلالـة الفروق بين المتوسطات الحسابية لمجموعات المبحوثين وفقاً لمستوي الاعتماد علي تلك المواقع في الحصول علي المعلومات حول القضايا المجتمعية ، تم استخدام الاختبار البعدي بطريقة أقل فرق معنوي • جدول (rr)

نتائج تحليل L.S.D لمعرفة مصدر الفروق بين متوسطات درجات المبحوثين ممن يستخدمون مواقع

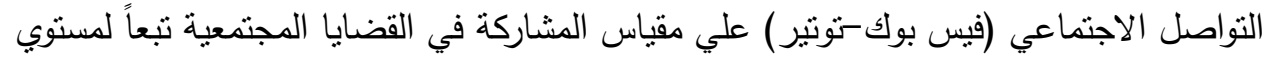

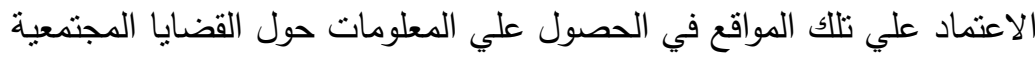

\begin{tabular}{|c|c|c|c|}
\hline منخفض & متوسط & مرتفع & المجموعات \\
\hline- & - & - & مرتفع \\
\hline- & - & $.0 Y$ & متوسط \\
\hline- &. .19 &. .09 & منخفض \\
\hline
\end{tabular}


يتضـح مـن الجـدول الـسابق اخـتلاف المتوسـطات الحسابية للمجموعـات التي تمثل مستويات اعتمـاد المبحوثين علي مواقع التواصل الاجتمـاعي في الحصول علي المعلومات حول القضايا المجتمعية ، حيث أكدت نتائج اختبار L.S.D

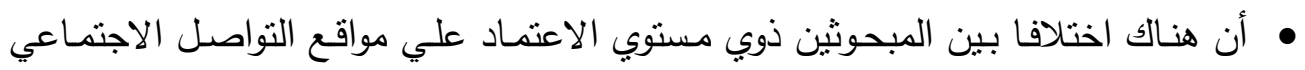

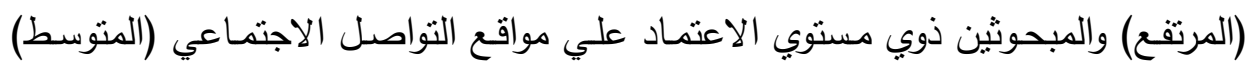

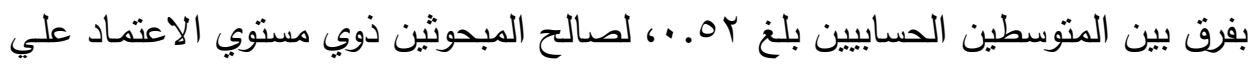

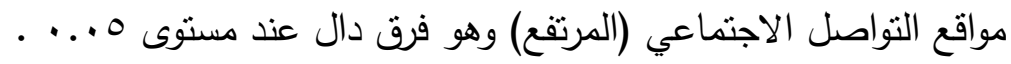

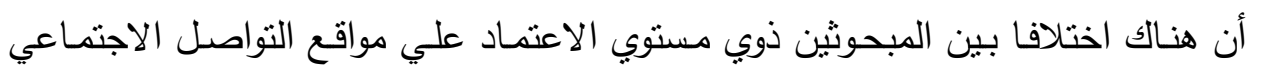

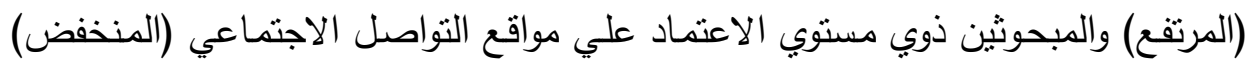

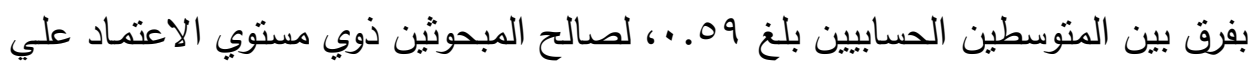

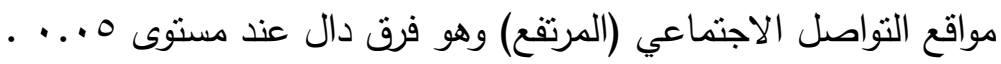
- مما سبق يتضح تحقق صحه الفرض الخامس. الفرض السادس: " توجد فروق دالة إحصائيا بين متوسطات درجات المبحوثين ممن الفئن

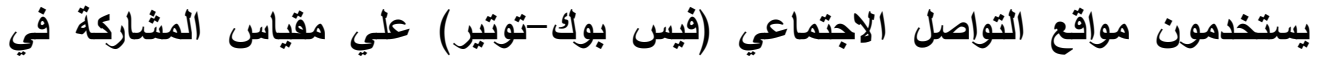

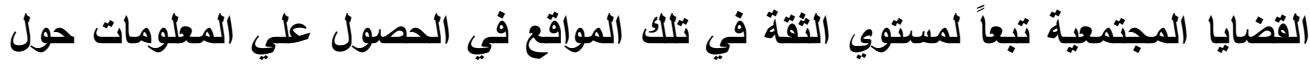

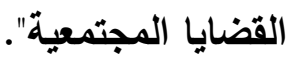

$$
\text { جدول (Tr) }
$$

نتائج اختبار تحليل التباين الأحاديلدلالة الفروق بين متوسطات درجات المبحوثين ممن يستخدمون

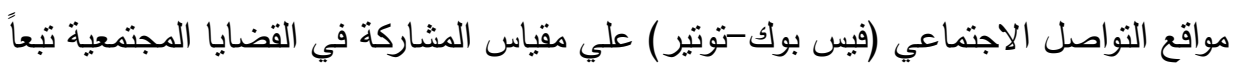
لمستوي الثقة في تلك المواقع في الحصول علي المعلومات حول القضايا المجتمعية

\begin{tabular}{|c|c|c|c|c|c|}
\hline الد ل الالة & قيمة ف & متوسط المربعات & درجة & مجموعات & مصدر التباين \\
\hline \multirow{3}{*}{$\ldots 0$} & \multirow{3}{*}{ T.MYO } & TY.rT. & r & $\vee \wedge .719$ & بين المجموعات \\
\hline & & سז1. & rqv & r..r.791 & داخل المجموعات \\
\hline & & & rqq & rqAr.r人. & المجموع \\
\hline
\end{tabular}

تشير نتـائج تطبيـق اختبـار " تحليـل التبـاين الأحسادي": إلـي عدم وجـود فـروق بـين متوسطات درجات المبحوثين ممن يستخدمون مواقع التواصل الاجتماعي (فيس بوك-توتير )

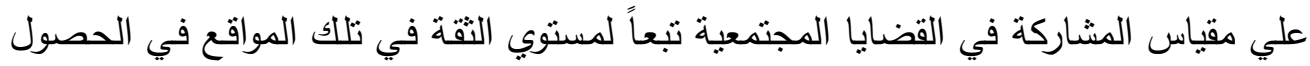




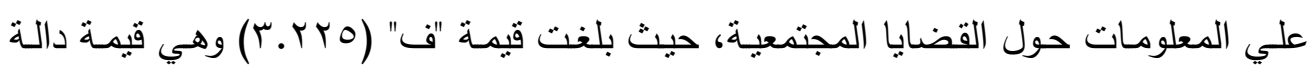

$$
\text { إحصائياً عند مستوي دلالة (0. ...). }
$$

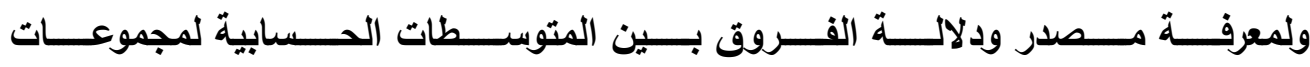
المبحوثين وفقاً لمستوي الثقة في مواقع التواصل الاجتماعي في الحصول علي المعلومات

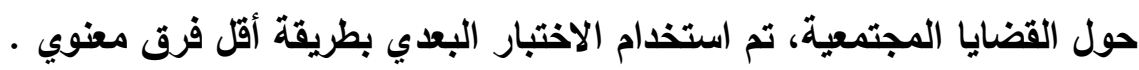

$$
\text { جدول (r ) }
$$

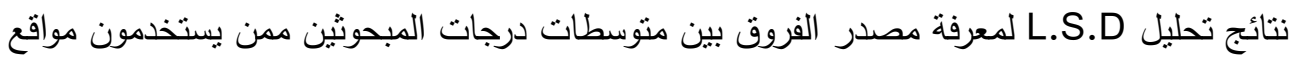

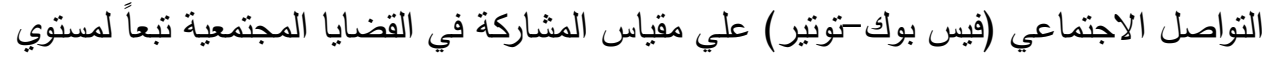

\begin{tabular}{|c|c|c|c|}
\hline أثق فيها بدرجة & أثق فيها بدرجة & أثق فيها بدرجة كبيرة & المجموعات \\
\hline- & - & - & أثثق فيها بدرجة كبيرة \\
\hline- & - &. $.7 \pi$ & أثق فيها بدرجة متوسطة \\
\hline- & $.0 Y$ &..$v 1$ & أتثق فيها بدرجة منخفضة \\
\hline
\end{tabular}

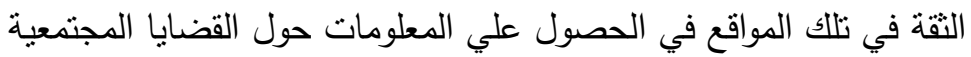

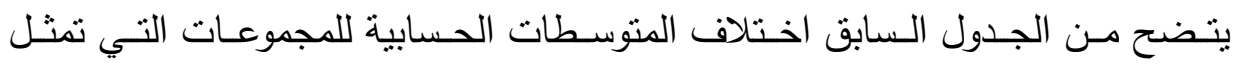

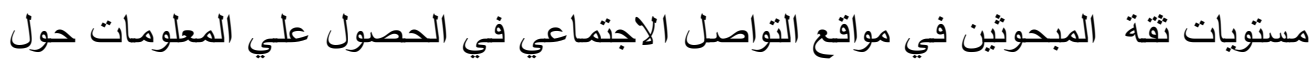

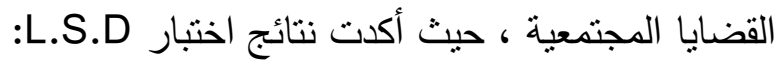

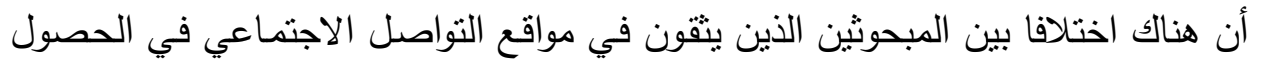

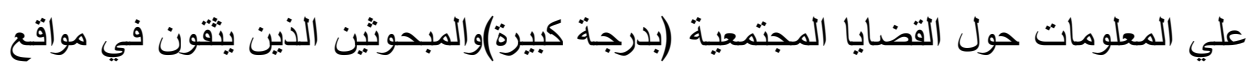

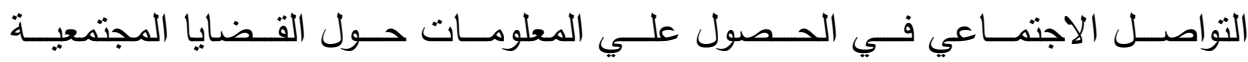

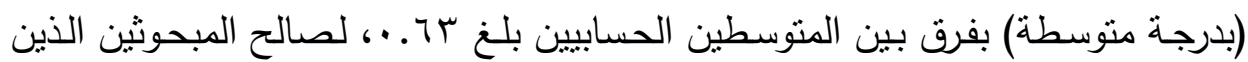

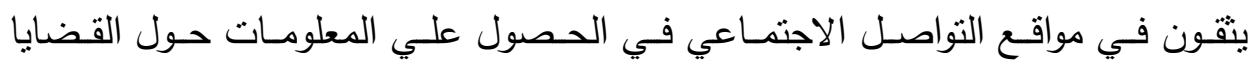

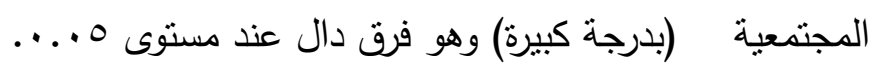

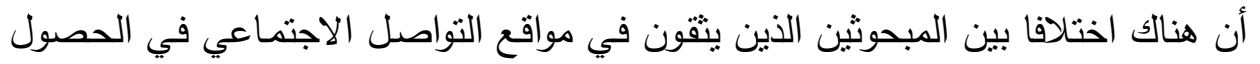

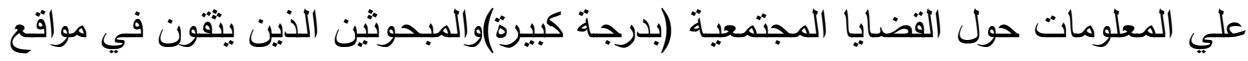

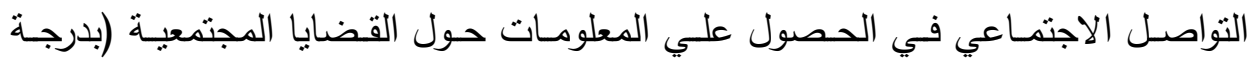

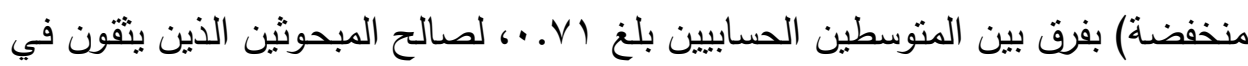

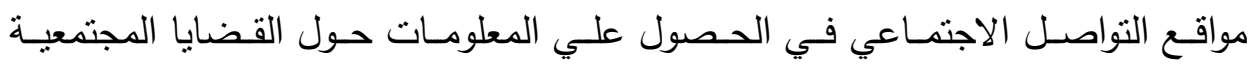

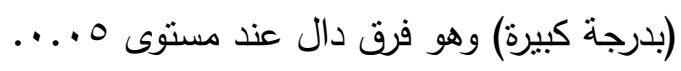

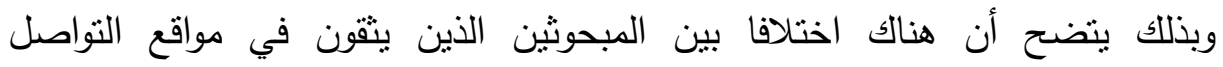

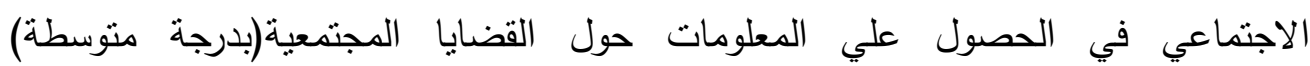
والمبحوثين الذين يثقون في مواقع التواصل الاجتماعي في الحصول علي المعلومات حول الديات 
القضايا المجتمعية (بدرجة منخفضة) بفرق بين المتوسطين الحسابيين بلغ به.or. ، لصالح

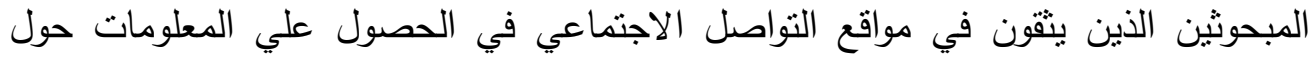

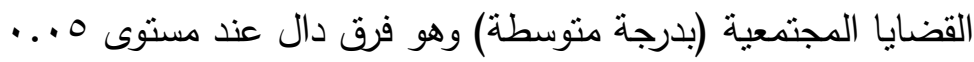

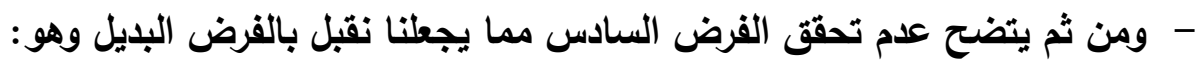
"لا توجد فروق بين منوسطات درجات المبحوثين ممن يستخدمون مواقع التواصل الاجتماعي

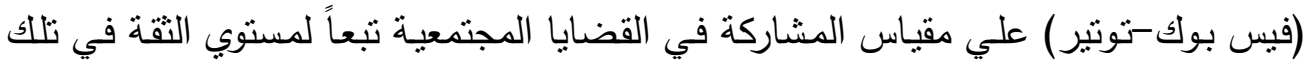
المواقع في الحصول علي المعلومات حول القضايا المجتمعية"

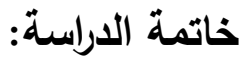

تتضمن الخاتمة أهم النتائج التي انتهت إليها الدراسة، إضافة إلى توصيات الدراسة.

أولاً: أهم نتائج الدراسة:

- - جاءت نسبة من يستخدمون مواقع التواصل الاجتماعي (فيس بوك - توتير ) دائماً في

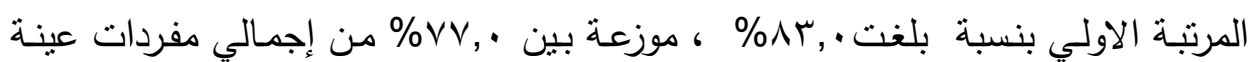

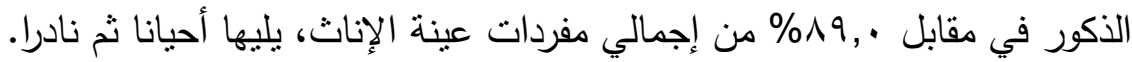

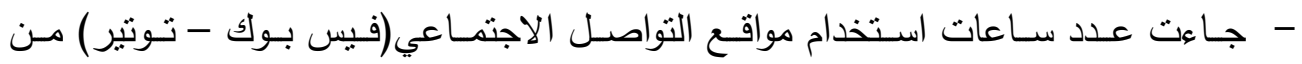

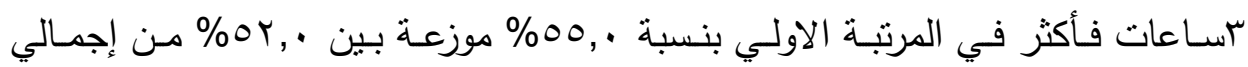

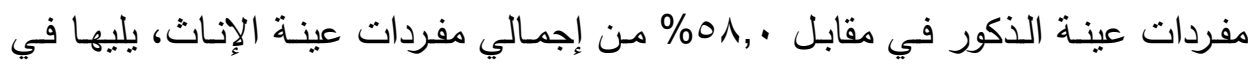
المرتبة الثانية أقل من ساعه يوميا ،وأخير من ساعة إلى ثنلاث ساعات يومياً في المرتبة الثالثة.

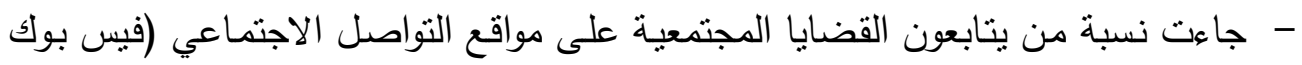

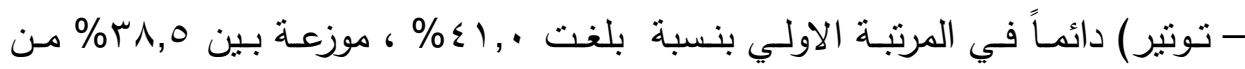

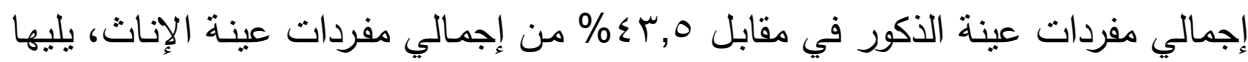
في المرتبة الثانية أحيانا، ثم نادرا في المرتبة الثالثة.

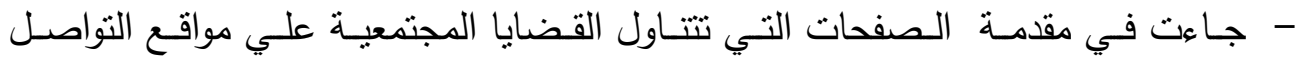
الاجتماعي(فيس بوك-توتير) ويشارك بها المبحوثون وفقاً للنوع ، صفحه قضايا سعودية

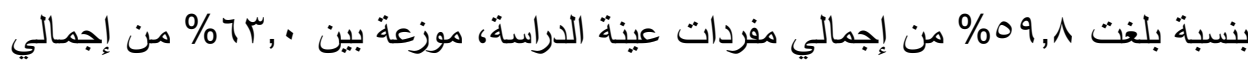

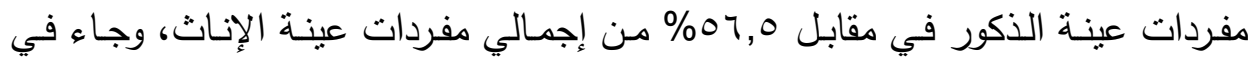
الترتيب الثاني صفحه قضايا اجتماعيه وتربوية سعودية ،وجاء في الترتيب الثالث صفحة قضايا المجتمع السعودي ،وجاء في التزتيب الرابع صفحة قضايا فنتات سعوديات. 


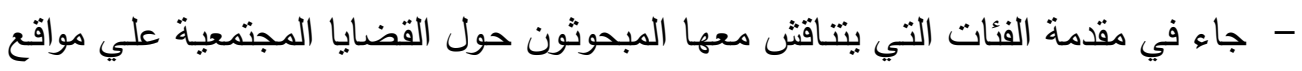

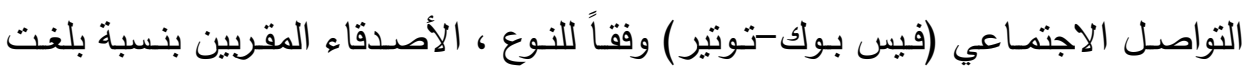

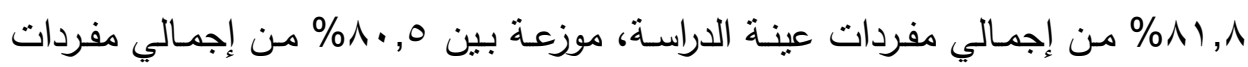

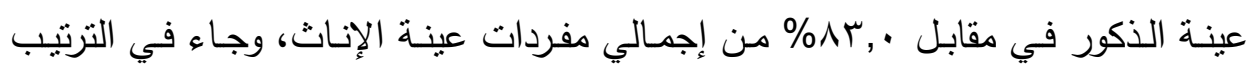

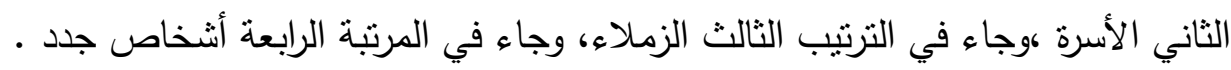

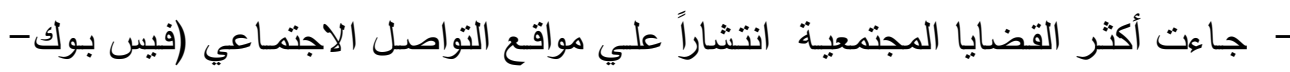

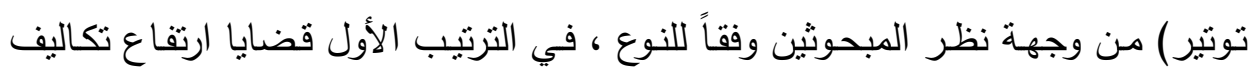

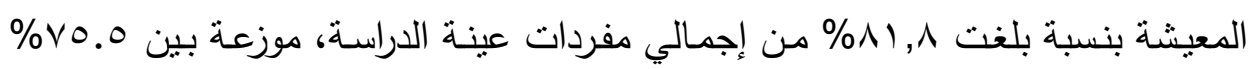

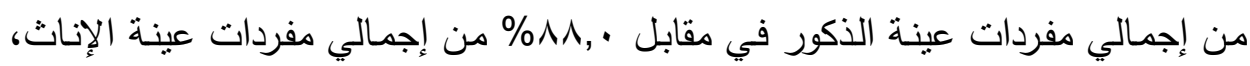

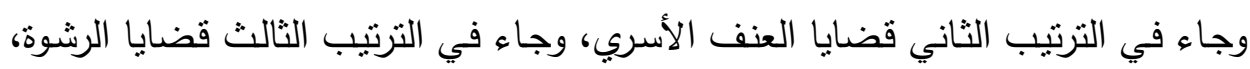

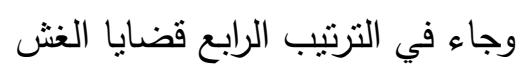
- وجاء في الترتيب الخامس قضايا المحسوبية وجاء في الترتيب السادس قضايا الطلاق ،جاء في الترتيب السابع قضايا التقحيط والتهور في قيادة الدرجات النارية.

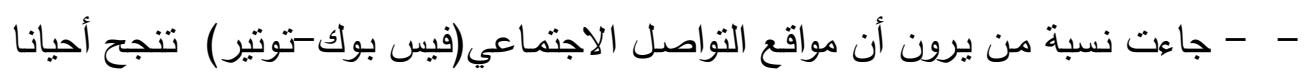

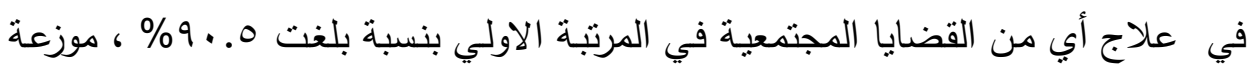

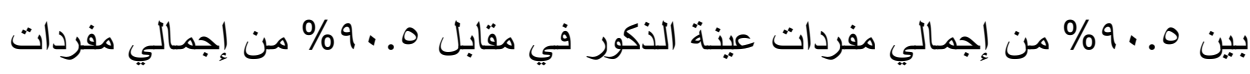
عينة الإناث، يليها نادرا ثم دائما في المرتبة الاخيرة.

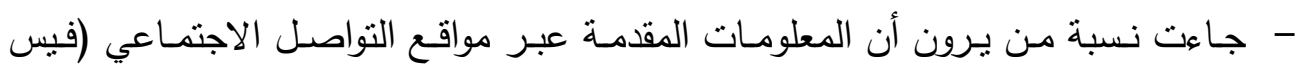

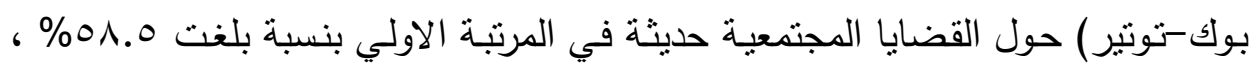

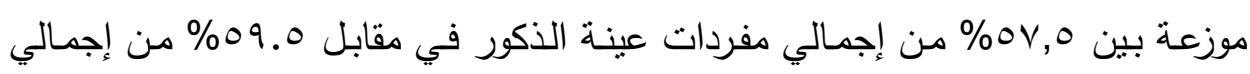

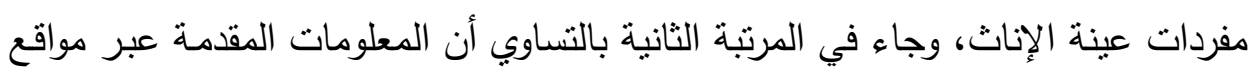
التواصل الاجتماعي (فيس بوك-توتير) حول القضايا المجتمعية هادفة وسطحية بنسبة الإنة

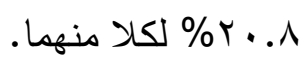
- - جاء دور المبحوثين تجاه المنشورات المتعلقة بالقضايا المجتمعيـة علي مواقع التواصل

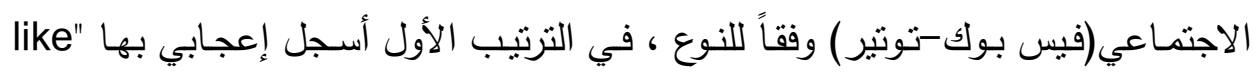

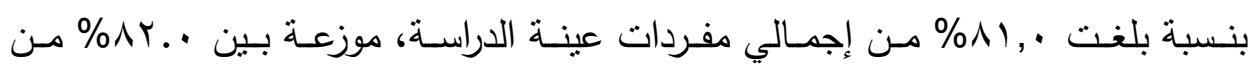

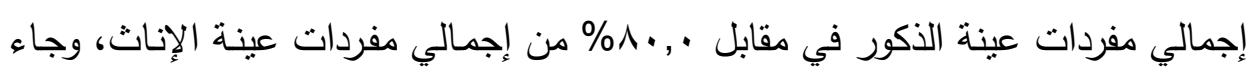




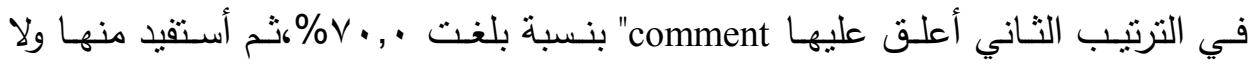

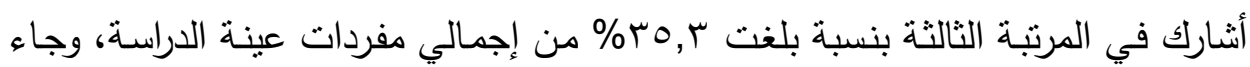

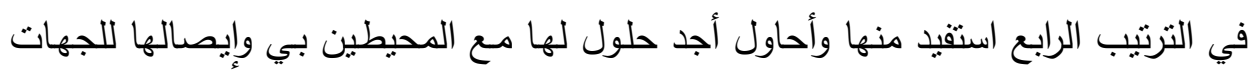

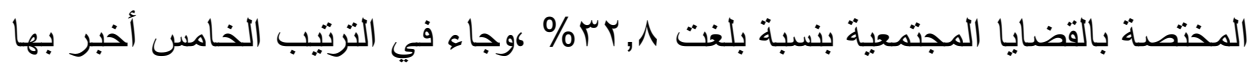

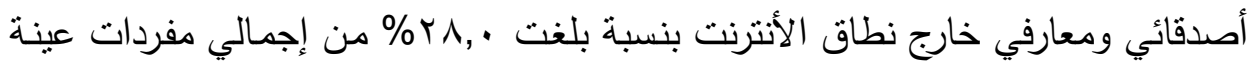

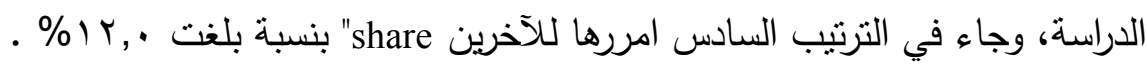

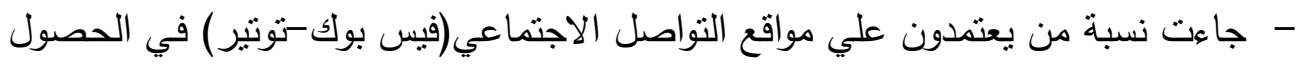

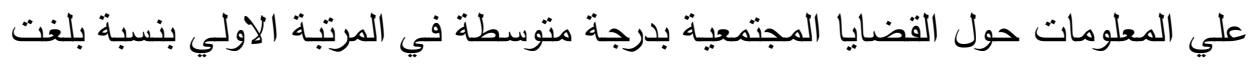

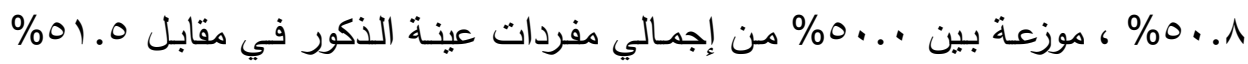
من إجمالي مفردات عينة الإناث، يليها بدرجة منخفضة، ثم بدرجة كبيرة في المرنبة الثالثة.

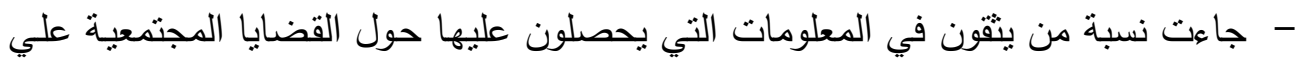
مواقع التواصل الاجتماعي(فيس بوك-توتير ) بدرجة منوسطة في المرتبة الاولي بنسبة

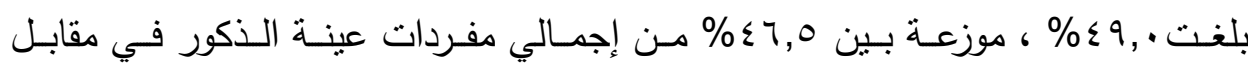

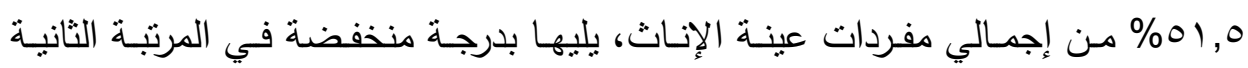

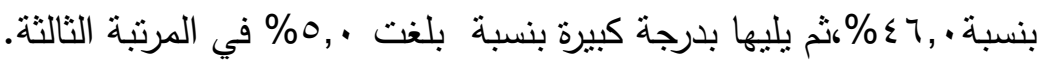

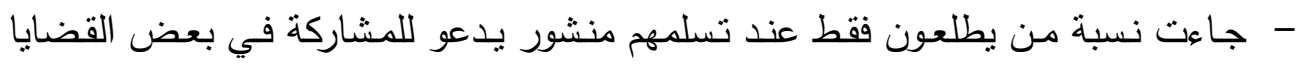

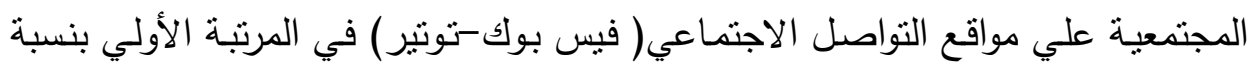

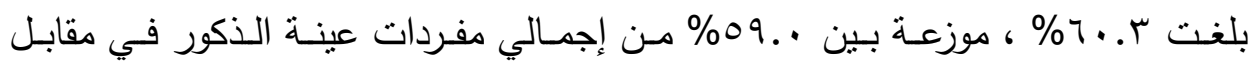
0. 1 \% من إجمالي مفردات عينة الإناث، يليها في المرتبة الثانية من يشاركون بفعالية

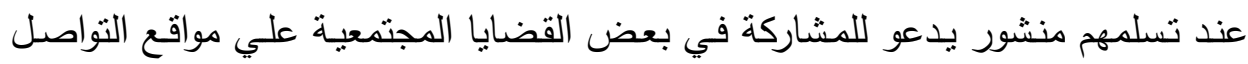

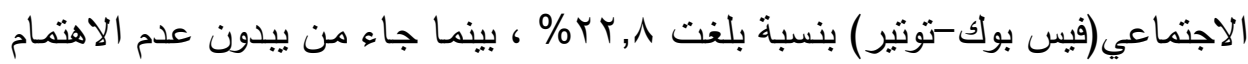
عند تسلمهم منشور يدعو للمشاركة في بعض القضايا المجتمية علي مواقع التواصل

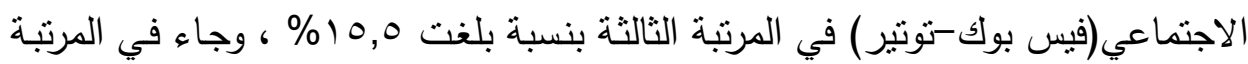
الرابعة من يقومون بحذف المنشور أو حظره عند تسلمهم منشور يدعو للمشاركة في في فئي

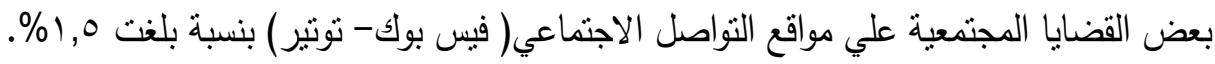

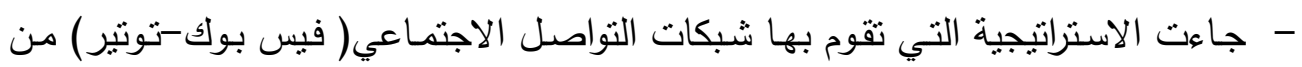

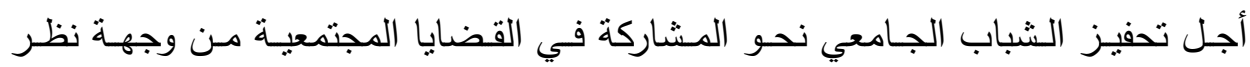


المبحوثين وفقاً للنوع ، في الترتيب الأول تعمل علي زيادة الوعي الثقافي بنسبة بلغت

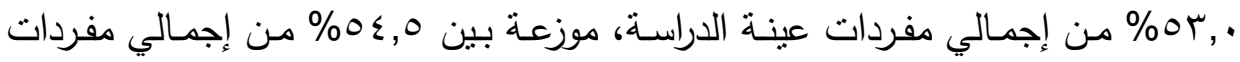

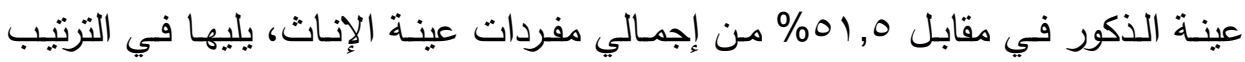

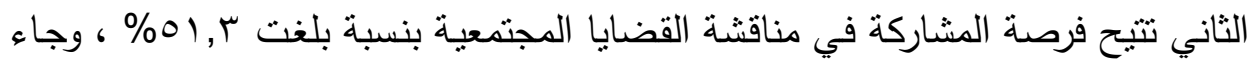

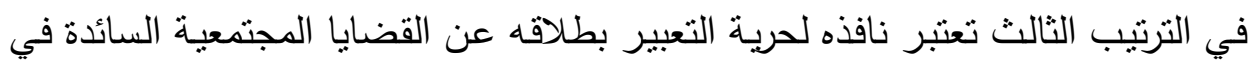
المجتمع بنسبة بلغت ^.^§٪ ،وجاء في الترتيب الرابع تعمل علي تقريب وجهات النظر

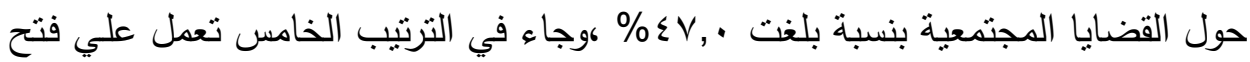

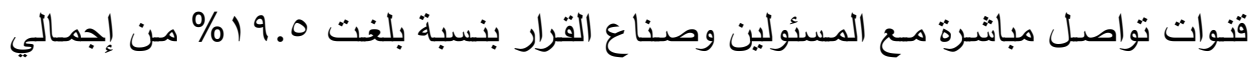

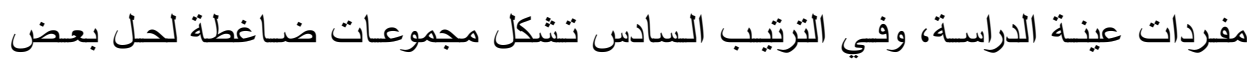

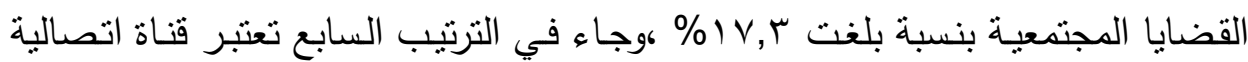

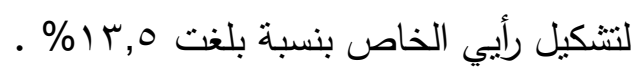
- جاءت أهم القضايا المجتمعية التي يهتم بمتابعتها المبحوثون ويبدون الرأي فيها من خلال

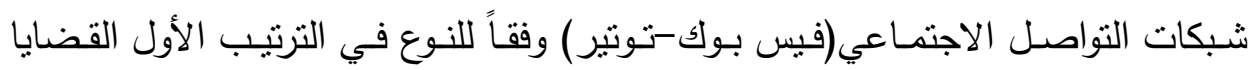

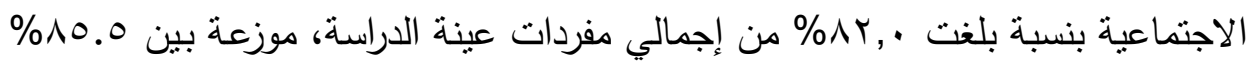

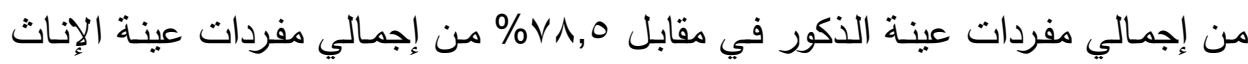

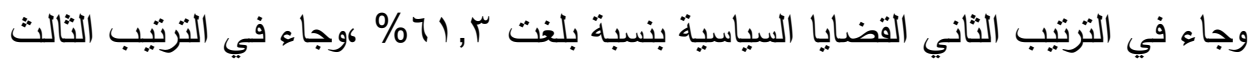

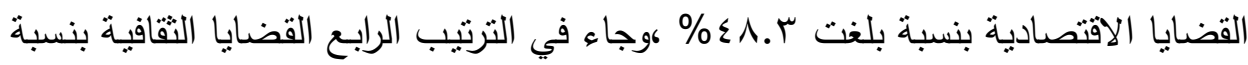

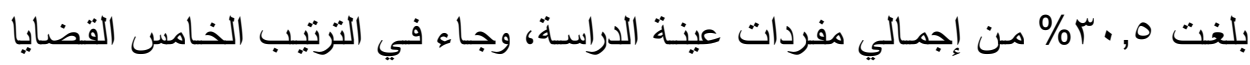

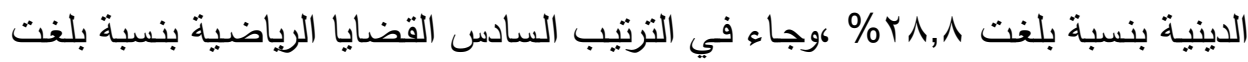
^. 1 ا \% من إجمالي مفردات عينة الدراسة. - - جـاءت اسـتجابات المبحـوثين علـي مقيـاس التـأثيرات الناتجـة عـن التعـرض للقضـايا المجتمعية علي مواقع التواصل الاجتماعي (فيس بوك-توتير ).

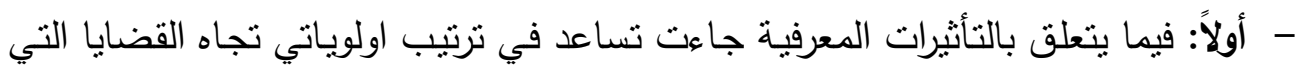

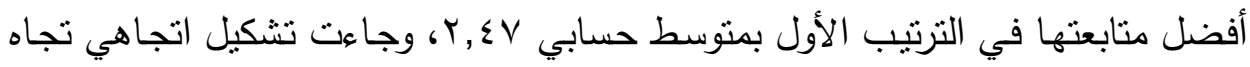
بعض الموضوعات والقضايا المثارة في مجتمعي في التزتيب الثناني بمنتوسط حسابي

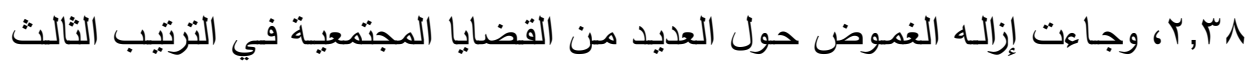

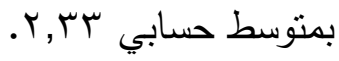


- ثانياً: فيما يتعلق بالتأثثرات الوجدانية جاءت تسبب لي شعور بالفتور واللامبالاة تجاه

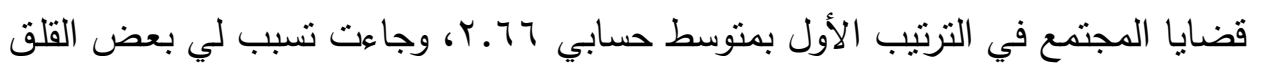

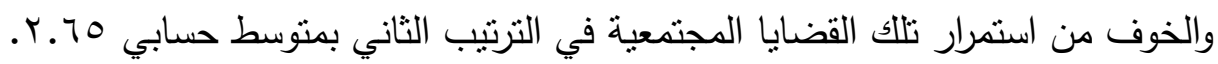
- ثالثاً: فيما يتعلق بالتأثيرات السلوكية جاءت تخلق لدي رغبه بالحماس والمشاركة بفعالية

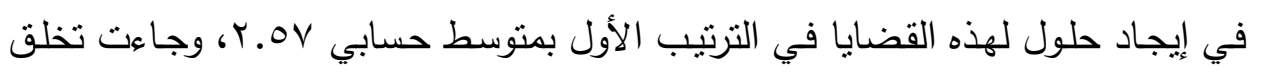
لدي رغبه في الخمول وتجنب القيام بأي تفاعل من القضايا المجتمعية في الترتيب السابع

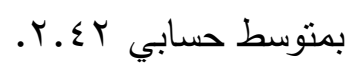

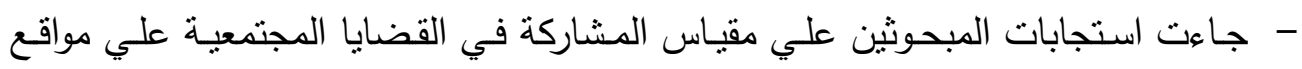

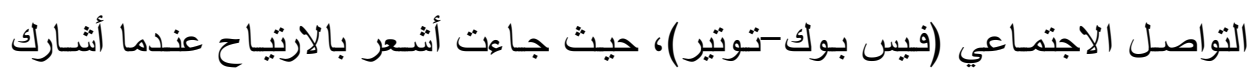
زملائي في عمل ناجح في الترتيب الأول ، وجاءت من الضروري معاقبه العامل المقصر

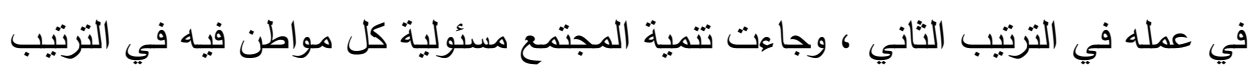

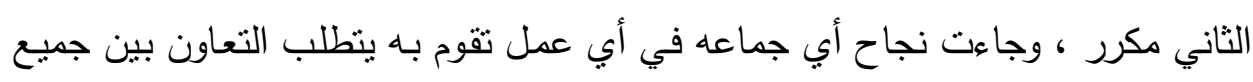

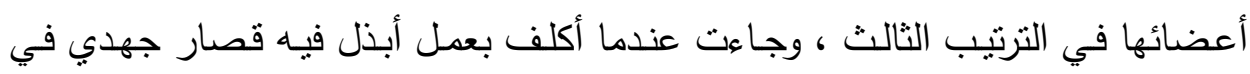
الترتيب الرابع ، وجاءت من واجبات كل مواطن أن يفهم خطط التنمية المجتمعية في بلده

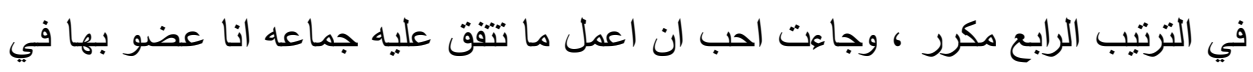

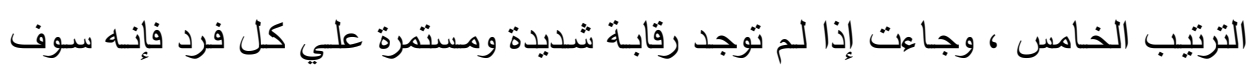
يهمل في عمله في التزتيب السادس وجاءت من واجب كل مواطن أن يقدم مقترحاته لحل قضايا مجتمعه في الترتيب السابع ، وجاءت كل فرد يستطيع ان يشارك في حل قضايا

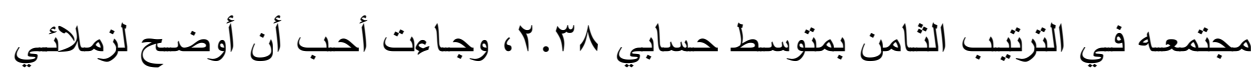

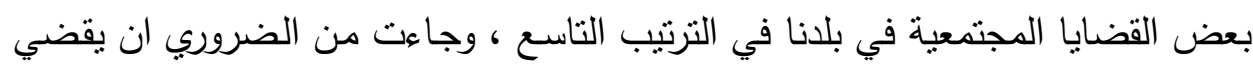

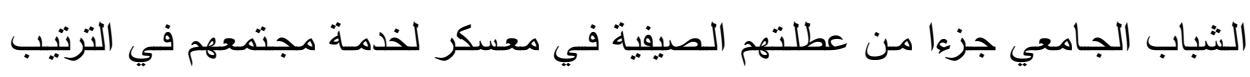

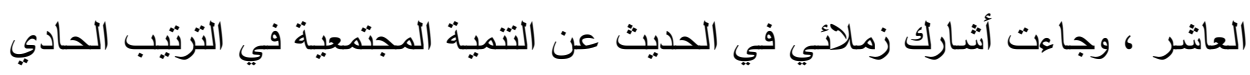

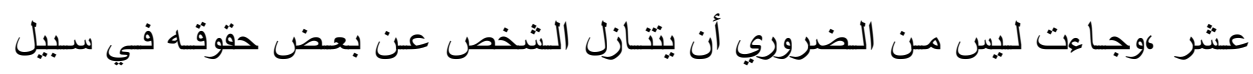

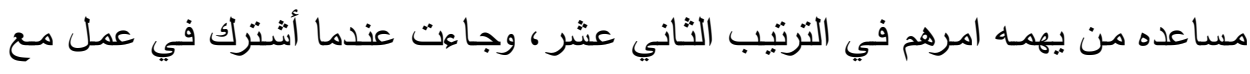

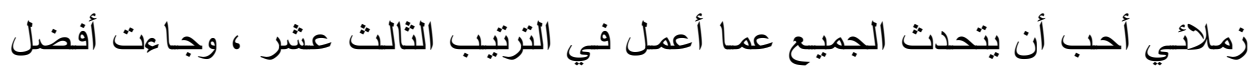

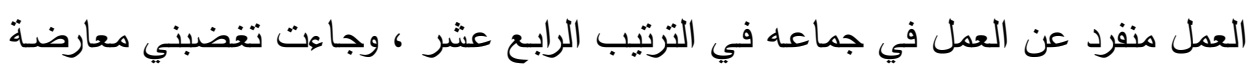

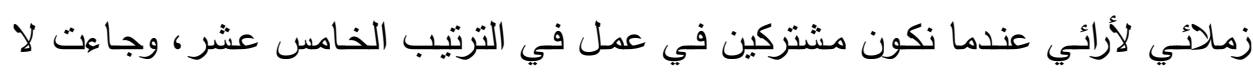


أحب ان أتحدث عن القضايا المجتمعية في بلدي في الترتيب السادس عشر ، وجاءت

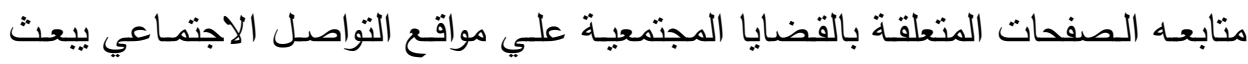

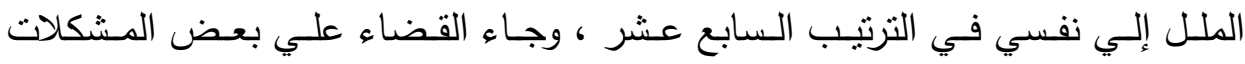

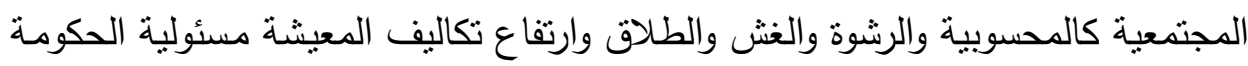

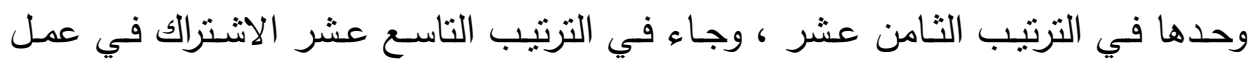

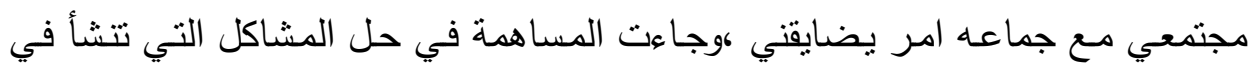
المجتمع من حولي ضياع وقت في الترتيب العشرون ،وجاءت بعض القضايا المجتمعية

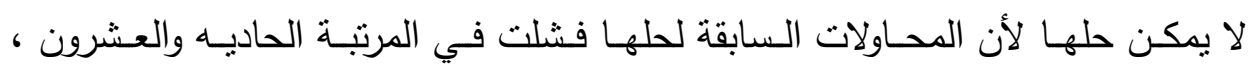
وجاءت في المرنبة الثانية والعشرون مناقشه القضايا المجتمعية وتبادل الرأي فيها يعطل

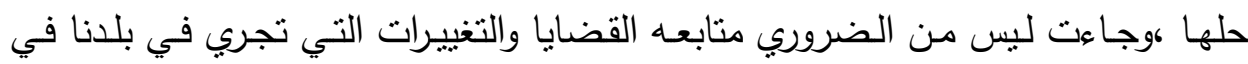

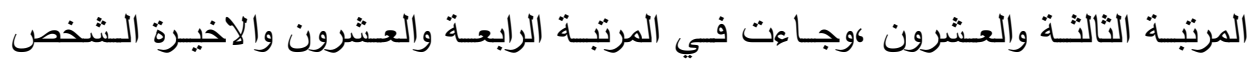
المخلص في عمله يفيد نفسه فقط وليس المجتمع • - تحقق صحه الفرض الأول القائل "توجد علاقة ارتباطيه دالة إحصائيا بين معدل استخدام ل

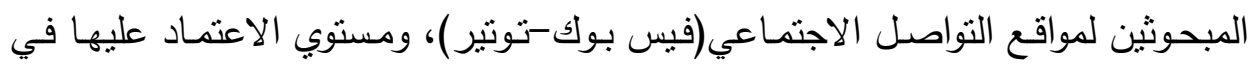
الحصول علي المعلومات حول القضايا المجتمعية". - تحقق صحه الفرض الثاني القائل "توجد علاقة ارتباطيه دالة إحصائيا بين كل من معدل

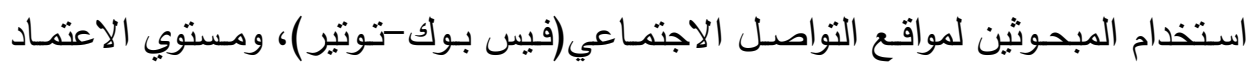

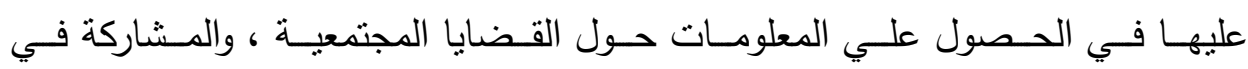
القضايا المجتمعية. - تحقق صحة الفرض الثالث جزئيا حيث اتضح عدم وجود فروق بين منوسطات درجات

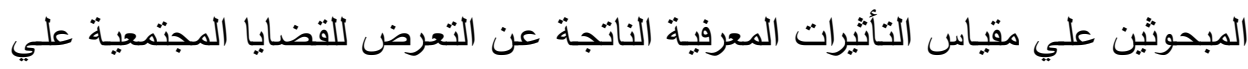

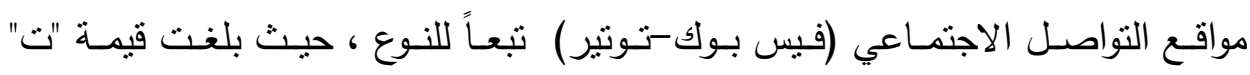
(0.0 (•) وهي قيمة غير دالة إحصائياً عند مستوي دلالة (0. ..).

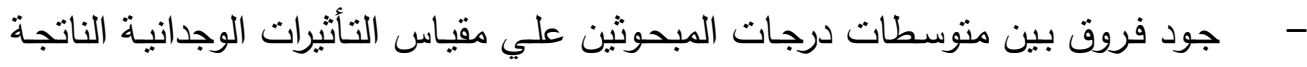

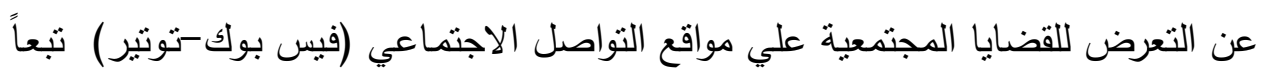

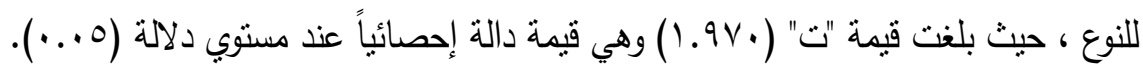


- وجود فروق بين منوسطات درجات المبحوثين علي مقياس التأثيرات السلوكية الناتجة عن

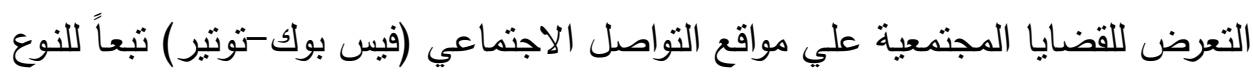

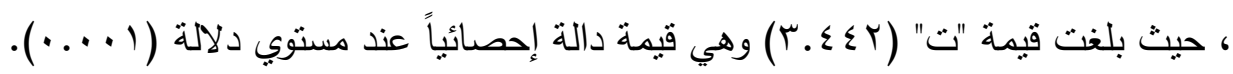

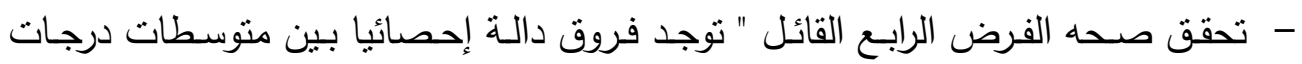

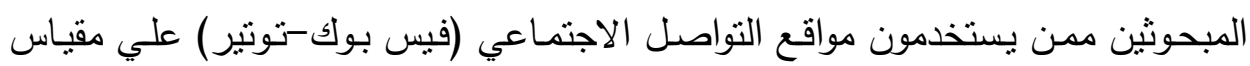
المشاركة في القضايا المجتمعية تبعاً للنوع. - تحقق صحه الفرض الخامس القائل " نوجد فروق دالة إحصائيا بين منوسطات درجات

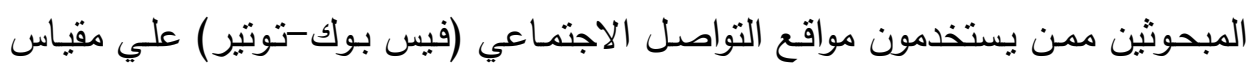

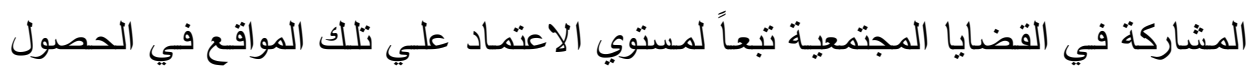
علي المعلومات حول القضايا المجتمعية. - لم ثبت صحة الفرض الساد القائل" توجد فروق دالة إحصائيا بين منوسطات درجات

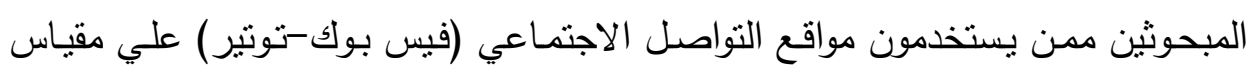

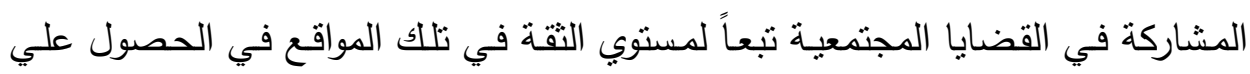
المعلومات حول القضايا المجتمعية".

\section{ثانياً: توصيات الدراسة:}

بناء على مناقثة أهم النتائج التي توصلت إليها الدراسة تقترح الباحثة ما يلى: توديات

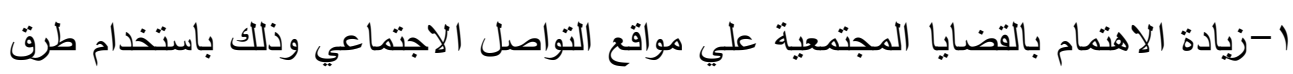

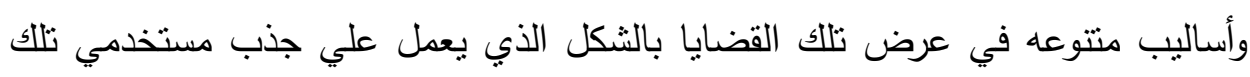
المواقع ويحفزهم علي المشاركة بفعالية في تلك القضايا.

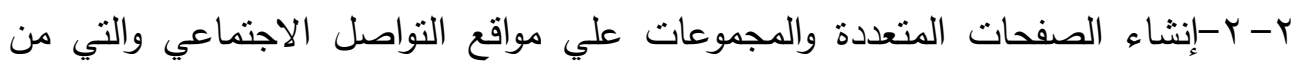
خلالها يتم تقديم العديد من المعلومات المتتوعة والهادفة عن القضايا المجتمعية علي اختلافها داخل المجتمع باعتبار ان مواقع التواصل الاجتماعي من أكثر المواقع إقبالا واستخداما من قبل الثباب. r-r-بتوظيف مواقع التواصل الاجتماعي بشكل اكثر فعالية بما لديها من إمكانيات وتأثير من أجل العمل علي معالجة القضايا المجتمعية. 
ع-ع-حث الثباب من خلال المنشورات والملصقات والإعلانات علي مواقع التواصل

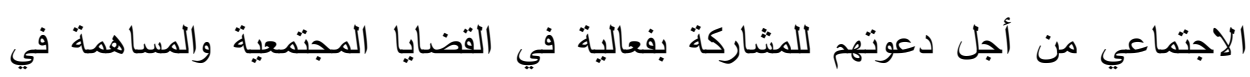
اقتراح الحلول لهذه القضايا باعتبارهم جزء لا يتجزأ من هذا المجتمع وان تلأك القضايا تمثل عقبة في سبيل تحقيق التتمية المستدامة لمجتمعاتهم.

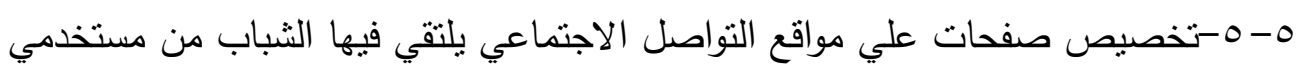
مواقع التواصل الاجتماعي والمسئولين في المجتمع ومتخذي القرار ولهم علاقة بالقضايا

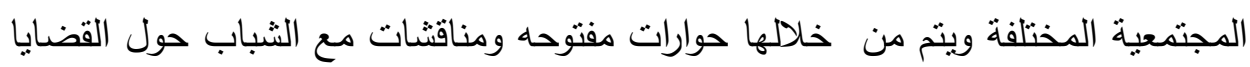
المجتمعية والاستماع لآرائهم ووجهات نظرهم لحل تلك القضايا من أجل تحقيق نتمية مستدامه لمجتمعاتهم معا. ؟- 1-توجيه نظر القائمين علي اتخاذ القرارات والجهات المسئولة حول أهميه مواقع التواصل الاجتماعي وضرورة الاستعانة بها كمكل لجهودهم من أجل دعم واستمرار مسيرة التتمية

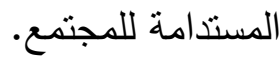


(1)http://www.albayan.ae/economy/last-deal/2014-10-06-1.2215557,(1/3/1437H,9:30p:m).

- Defleur. Melvin and Sandra Ball-Rokeach, Theories of Mass Communication,

Fourth Edition, (New York: Longman, 1982) pp. 242-250.

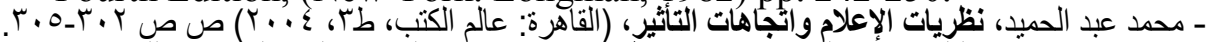

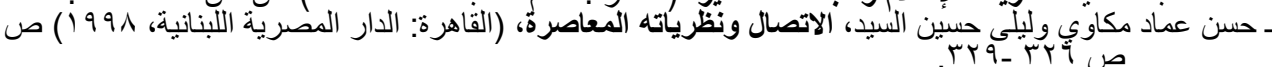

3-Loges, William . Perception of Threat and System Dependency Relation . In: Communication Research, Vol:1, 1994 . Pp. 78 - 79.

${ }^{4-}$ McQuail, Denis\& Windhal, Suen. Communication Models. (London : Longman, 1993) Pp. $114-115$.

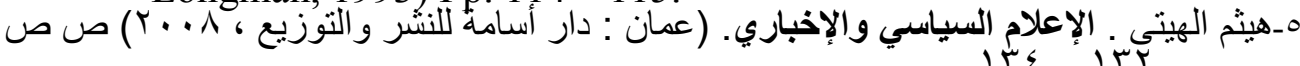

6-Pierce, C. John, Lee- Sammons, Lynette, Steger, E. Mary Ann, and Jr. Lovrich, P. Nicholas. "Media Reliance and Public Images of

Environmental Politics in Ontario and Michigan". Journalism Quarterly. V. 67. N.4. Winter, 1990. P. 838.

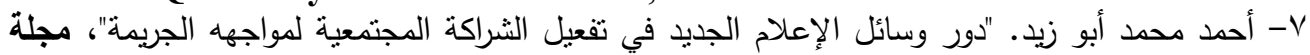

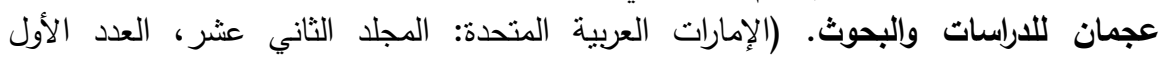

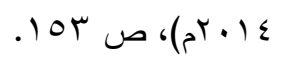

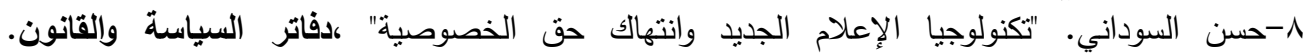

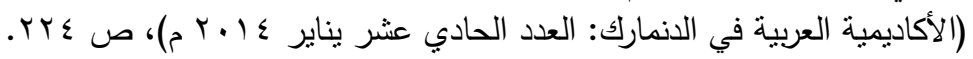

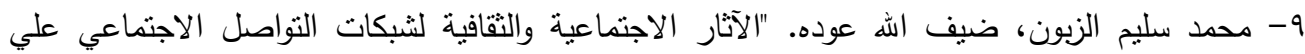

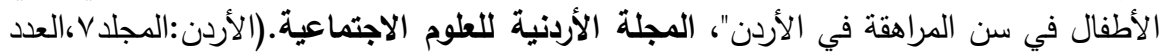

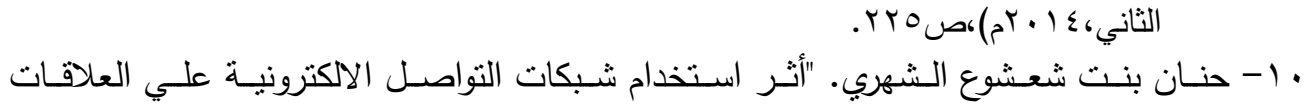

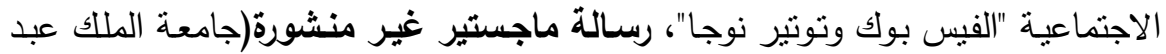

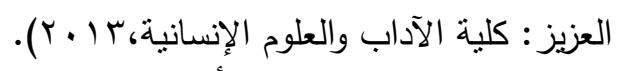

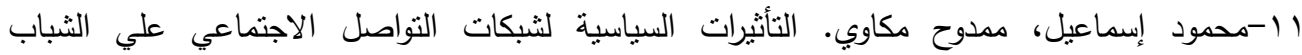

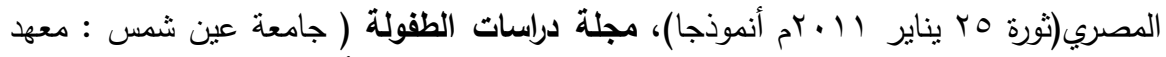

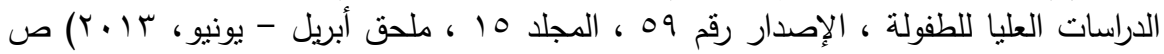

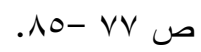

12-Meredith Conroy,M,. Jessica, T\& Guerrero,F " Face book and political engagement: A study of online political group membership and offline political engagement "Computers in Human Behavior, In Press, Corrected Proof, 24 April 2012 Available online:www.sciencedirect.com

13-Cheung, , .. Chiu ,P \& Lee ,M (2011) " Online social networks: Why do students use facebook?" In Computers in Human Behavior, Vol (27) p.p1337-1343.

ع ا-أحمد يونس حمودة. "دور شبكات التواصل الاجتماعي في تتمية مشاركة الثباب الفلسطيني في

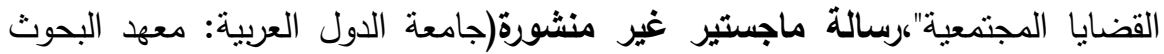

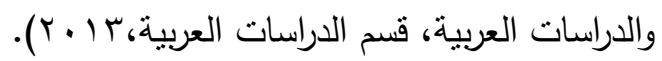

${ }^{15-B o r o u g h s, B ~ " s o c i a l ~ n e t w o r k i n g ~ w e b s i t e s ~ a n d ~ v o t e r ~ t u r n o u t ~ " . ~ U n p u b l i s h e d ~ M . A ~}$ (Washington,Dc : Georgetown University.2010) 
7 ا-محمود عبد القوي. "دور الإعلام البديل في تفعيل المشاركة السياسية لدي الشباب: دراسة

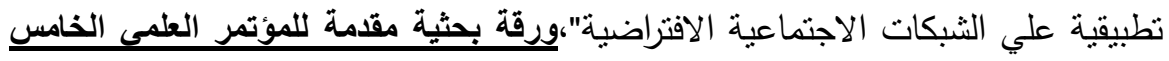

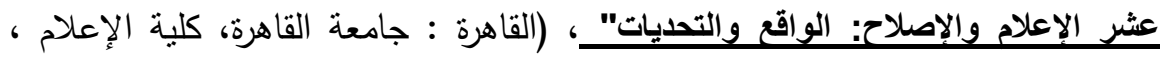

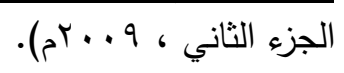

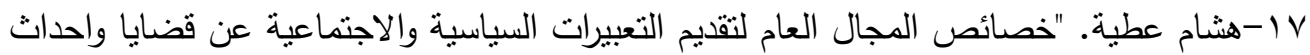

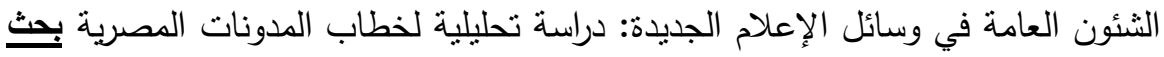

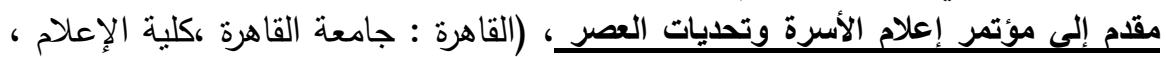

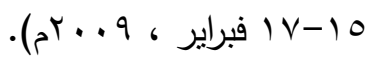

18-Rebecca,A.Hayes(2009 New media, new politics: Political learning efficacy and the examination of uses of social network sites for political engagement, Unpublished Ph.D, (MICHIGAN STATE UNIVERSITY),On line: http://gradworks.umi.com/33/96/3396059.html(27/7/1437,8:21P:m)

19-Matthew j.Kushin\&Masashhiro Yamamoto,"Did social media matter?college student"Use of on line media and political decision making in the 2008 election,paper presented to association for education in journalism\&mass communication,(Boston,USA,2009).Online: http:/www.allacademic.com/meta/p375251 index.html(27/7/1437,9:10 P:m).

${ }^{20-}$ Weiwu Zhanga* \& Stella C. Chia.(2006),The Effects of Mass Media Use and Social Capital on Civic and Political Participation, communication studies.Vol.57,Issue 3,pages 277-297.0n line: http://www.tandfonline.com/doi/abs/10.1080/10510970600666974,(27/7/1437,10:00P:m).

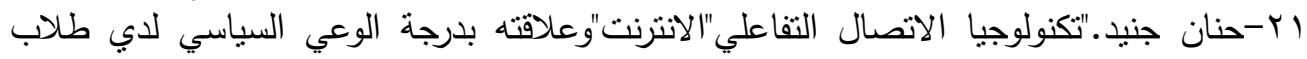

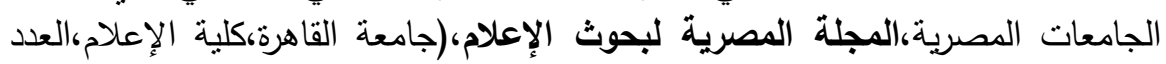

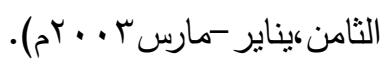

r ب-وليد فتح الله بركات. "اعتماد الثباب الجامعي الكويتي علي وسائل الإعلام في المعرفة بالقضايا

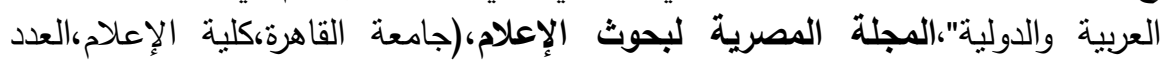

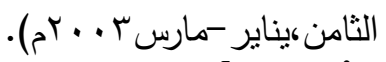

23-Hou.Cheng-N\&Ming-H,"Creating the internet as alternative media "paper present at the annual meeting of the American sociological association, Atlanta, GA,(2003) Aug16.

* أسماء السادة المحكمين مرتبة ترتيباً أبجديا ( أحب الارجة العلمية):

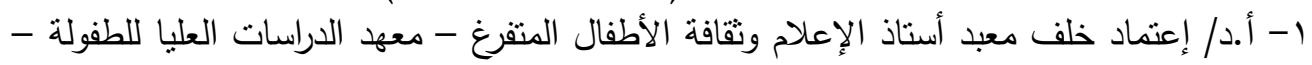
جامعة عين شمس

r-أ.د/محمد غريب أستاذ الإعلام بقسم الإعلام - كلية الآداب - جامعة الزقازيق

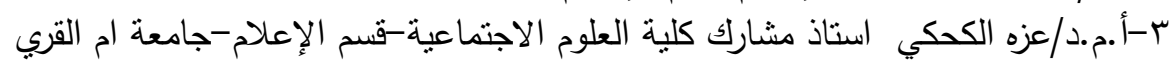

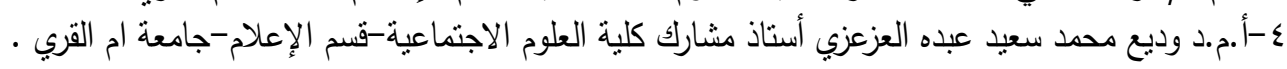

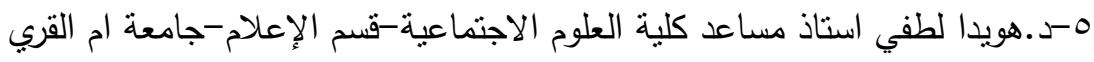

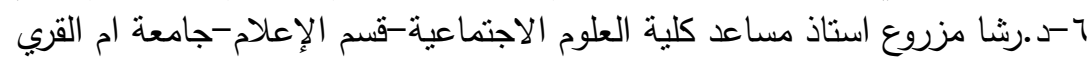

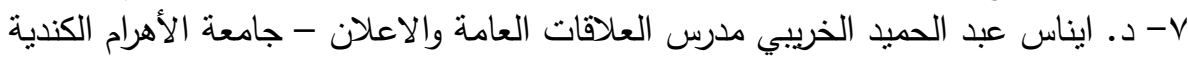
^-د.أشرف قادوس مدرس الإعلام - جامعة مصن مدراته-ليبيا

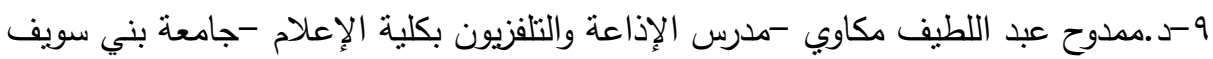

